JULIA DA ROSA HOWAT RODRIGUES

PROJETO E CONSTRUÇÃO DE UM SIMULADOR SOLAR CONCENTRADOR 
JULIA DA ROSA HOWAT RODRIGUES

PROJETO E CONSTRUÇÃO DE UM SIMULADOR SOLAR CONCENTRADOR

Dissertação apresentada à Escola Politécnica da Universidade de São Paulo para obtenção do título de Mestre em Ciências

São Paulo 
JULIA DA ROSA HOWAT RODRIGUES

\title{
PROJETO E CONSTRUÇÃO DE UM SIMULADOR SOLAR CONCENTRADOR
}

\author{
Dissertação apresentada à Escola \\ Politécnica da Universidade de São \\ Paulo para obtenção do título de \\ Mestre em Ciências \\ Área de Concentração: \\ Engenharia Mecânica de Energia e \\ Fluidos
}

Orientador:

Prof. Dr. José Roberto Simões Moreira

São Paulo 
Este exemplar foi revisado e corrigido em relação à versão original, sob responsabilidade única do autor e com a anuência de seu orientador.

São Paulo, de de

Assinatura do autor:

Assinatura do orientador:

Catalogação-na-publicação

Rodrigues, Julia

PROJETO E CONSTRUÇÃO DE UM SIMULADOR SOLAR

CONCENTRADOR / J. Rodrigues -- versão corr. -- São Paulo, 2016.

$98 \mathrm{p}$.

Dissertação (Mestrado) - Escola Politécnica da Universidade de São Paulo. Departamento de Engenharia Mecânica.

1.Energia Solar 2.Simulador Solar 3.Alto Fluxo 4.Concentrador Solar 5.Alta Temperatura I.Universidade de São Paulo. Escola Politécnica. Departamento de Engenharia Mecânica II.t. 


\section{DEDICATÓRIA}

À minha família, pelo amor incondicional e por todo apoio e confiança, me fazendo sempre acreditar que qualquer sonho é possível. Ao meu amor, Vinicius Ribas, pelo companheirismo e motivação ao longo de toda essa trajetória. 


\section{AGRADECIMENTOS}

Agradeço primeiramente ao professor orientador Dr. José Roberto Simões Moreira que tornou possível a conclusão deste projeto, contribuindo não só com sua experiência e sabedoria, mas com a participação ativa nas atividades. Serei sempre grata pelo confiança e amizade que nos tornaram uma equipe.

Ao professor Dr. José Maurício Alves de Matos Gurgel da Universidade Federal da Paraíba, pela cordialidade com a qual me recebeu em seu laboratório e por disponibilizar toda a infraestrutura e suporte para a confecção do refletor parabólico.

Ao pesquisador Dr. Gustavo de Andrade Barreto, pela generosidade em compartilhar seu conhecimento e pela prontidão em ajudar-me sempre que solicitado. Sua contribuição na instrumentação dos testes foi essencial para a conclusão deste projeto.

Ao SISEA - Laboratório de Sistemas Energéticos Alternativos - POLI - USP, pela infraestrutura disponibilizada, e ao técnico Thyago Reynaldo, pelo excelente trabalho prestado na montagem e construção do protótipo. À Escola Politécnica (e todos os seus professores), pela oportunidade de desenvolvimento acadêmico e pessoal, e por tornar-se meu segundo lar nestes últimos oito anos.

À FAPESP - Fundação de Amparo à Pesquisa do Estado de São Paulo - pela bolsa de mestrado concedida (processo $n^{\circ} 2013 / 03721-0$ ) e pelo apoio financeiro para a construção do simulador solar (Auxílio à Pesquisa - processo n²014/01517-0).

Finalmente, agradeço à minha família, pelo apoio e confiança, e ao meu amor e melhor dupla de trabalho, Vinicius Ribas, pelo companheirismo e paciência nos momentos de dificuldade. Com vocês, gostaria de comemorar mais essa conquista. 
"O único lugar onde o sucesso vem antes do trabalho é no dicionário."

(Albert Einstein) 


\section{RESUMO}

Segundo o Atlas Brasileiro de Energia Solar, apesar das diferentes características climáticas observadas no Brasil, pode-se constatar que a média anual de irradiação solar global apresenta boa uniformidade e elevados índices por todo o país. Os valores desta grandeza em quase toda a extensão do território brasileiro (4200-6700 $\mathrm{Wh} / \mathrm{m}^{2} / \mathrm{dia}$ ) são superiores aos da maioria dos países da União Europeia, como Alemanha (900-1250 Wh/m²/dia), França (900-1650 Wh/m²/dia) e Espanha (1200$\left.1850 \mathrm{Wh} / \mathrm{m}^{2} / \mathrm{dia}\right)$, onde projetos para aproveitamento de energia solar, alguns contando com fortes incentivos governamentais, são amplamente disseminados.

Grande parte dos avanços científicos obtidos nos estudos sobre aproveitamento da energia solar se deve à utilização de simuladores solares compactos nos experimentos de longa duração. Ao substituir o Sol por fontes artificiais, como lâmpadas capazes de emitir radiação próxima à solar, os simuladores eliminam a dependência de fatores naturais como condições climáticas, horário do dia, intermitência e movimento de direção da radiação solar.

O projeto proposto para esta dissertação de Mestrado teve como objetivo o domínio do processo de concepção e fabricação de um simulador solar concentrador formado por lâmpadas e um refletor ótico. Uma vez dominada a técnica, um modelo piloto de simulador solar foi construído e alguns testes executados para avaliar a qualidade do projeto, a resistência dos componentes e o fator de concentração do aparato.

Palavras-chave: Energia Solar; Simulador Solar; Alto Fluxo; Concentrador Solar; Alta Temperatura. 


\begin{abstract}
According to the Brazilian Atlas of Solar Energy, despite the different climatic characteristics observed in Brazil, the annual average of global solar irradiation has good uniformity and high levels throughout the country. The values of global solar irradiation in almost the entire length of Brazil (4200-6700 Wh/m²/day) are higher than those observed in most European Union countries, like Germany (900-1250 $\mathrm{Wh} / \mathrm{m}^{2} /$ day), France (900-1650 Wh/m²/day) and Spain $\left(1200-1850 \mathrm{Wh} / \mathrm{m}^{2} /\right.$ day $)$, where projects for solar energy applications, some of them relying on strong government incentives, are widely disseminated.
\end{abstract}

Several scientific and technological advances made in the study of solar energy applications are due to the use of compact solar simulators in long-term experiments. Replacing the Sun by artificial sources, such as arc lamps with radiation emission similar to the Sun spectrum, indoor simulators avoid the dependence on natural conditions such as the weather, the daytime, the sunlight intermittence and the directional change of the solar radiation.

The project proposed for this dissertation aimed to master the design and manufacturing processes of a high-flux solar simulator consisting of arc lamps and an optical reflector. Once technique was understood, a solar simulation pilot model was built and some tests were performed to assess the project quality, the resistance of components and the apparatus concentration factor.

Keywords: Solar Energy; Solar Simulator; High Flux Radiation; Concentrating Solar Power; High Temperature. 


\section{LISTA DE ILUSTRAÇÕES}

Figura 2.1 - Configuração de concentradores solares (A) Sistema cilindro parabólico (B) Sistema de torre (C) Sistema de disco - adaptado de Steinfeld e Meier (2004) .19 Figura 2.2 - Espectro de irradiância da radiação solar no topo da atmosfera (linha sólida) e ao nível do mar (sombreado) em comparação ao espectro de um corpo negro (linha tracejada) - adaptado de Andrews (2010) 21

Figura 2.3 - Exemplo de balanço global da radiação solar para uma determinada região - adaptado de ClimaGeo: Comunidade de Climatologia (2015) .22

Figura 2.4 - Arranjo ótico formado por dez lâmpadas de xenônio do tipo №3 adaptado de Petrash et al (2007) .24

Figura 2.5 - Arranjo experimental de simulador solar - adaptado de Meier e Sattler (2009) .25

Figura 2.6 - Simulador solar de alto fluxo do PSI (Petrash et al, 2007) .29

Figura 2.7 - Simulador solar concentrador do MIT - adaptado de Codd et al (2010) 30

Figura 2.8 - Simulador solar do DLR em operação (Alxneit e Dibowski, 2011) 31

Figura 2.9 - Um dos conjuntos formados por lâmpada e refletor (Erickson, 2012) ...31

Figura 2.10 - Simulador solar do SER em operação - adaptado de SER Laboratory: Texas A\&M University at Qatar (2016) .32

Figura 3.1 - Lâmpada de xenônio e sua distribuição espectral de potência emissiva radiativa - adaptado de Superior Quartz Products Inc. (consulta em 2013) 34 Figura 3.2 - Processo iterativo de aplicação e avaliação dos conjuntos de filtros ....35 Figura 3.3 - Processo de repuxo para fabricação dos refletores (esquerda) e modelo de um refletor (direita) - adaptado de Alxneit e Dibowski (2011) .36 
Figura 3.4 - Potências irradiantes médias e totais no plano do receptor - adaptado de Petrash et al (2007) .40

Figura 3.5 - Sky Search Lights de 4.000W de potência da marca HOLLE 43

Figura 3.6 - Configuração final proposta para o simulador solar 44

Figura 3.7 - Layout da instalação completa do simulador solar.... .45

Figura 4.1 - Visão geral do sistema e seus principais componentes .46

Figura 4.2 - Principais dimensões do refletor parabólico e resultado após revestido com película autoadesiva refletora .48

Figura 4.3 - Sky Search Light adquirido como fonte luminosa do simulador solar ...49 Figura 4.4 - Suporte móvel para fixação de cavidades receptoras no foco do concentrador com três graus de liberdade e aparato final montado. .50

Figura 4.5 - Cavidade receptora, com destaque para sua serpentina interna de cobre .51

Figura 4.6 - Montagem final da cavidade receptora .52

Figura 4.7 - Destaque para: (a) sensor de vazão volumétrica - rotâmetro; (b) trocador de calor - radiador automotivo e (c) válvula de expansão do circuito de água

Figura 4.8 - Destaque para a motobomba Schneider ${ }^{\circledR}$ de $1 / 4$ CV. .54

Figura 4.9 - Arranjo experimental completo. .54

Figura 5.1 - Distribuição espectral da potência emissiva radiativa de uma lâmpada de xenônio e de um corpo negro (Sol) a $5780 \mathrm{~K}$ (Petrash et al, 2007). 55 Figura 5.2 - Componentes internos de um espectrômetro e representação esquemática de seu funcionamento .56 Figura 5.3 - Espectrômetro USB2000+XR1 da Ocean Optics adquirido para testes no simulador solar .57 
Figura 5.4 - Bancada de testes óticos

Figura 5.5 - Esquema ilustrativo das principais perdas ao longo do percurso luminoso. 60

Figura 5.6 - Representação esquemática do simulador solar e da variação da quantidade de energia ao longo do percurso luminoso 61

Figura 6.1 - Resultado do teste de irradiância relativa - distribuição de intensidade emissiva por comprimento de onda.

Figura 6.2 - Configuração final do arranjo experimental após etapa de alinhamento e posicionamento de seus componentes 66

Figura 6.3 - Diferença de temperatura da água na entrada e na saída da cavidade receptora à $200 \mathrm{~L} / \mathrm{h}$ 67

Figura 6.4 - Fluxo de calor no circuito de água em função do tempo 68

Figura 6.5 - Temperatura no interior da cavidade receptora em função do tempo ...70 Figura 6.6 - Distribuição de temperatura nas superfícies do concentrador e da cavidade receptora após os testes .71

Figura A.1.1 - Molde parabólico em vidro da UFPB e suas características dimensionais .79

Figura A.1.2 - Processo de limpeza do molde e resultado após o polimento .80

Figura A.1.3 - Resultado da aplicação de Gel Coat sobre o molde .81

Figura A.1.4 - Sequência de aplicação das camadas de resina e manta de vidro ...81

Figura A.1.5 - Etapa de cura após se atingir a espessura desejada da peça .81

Figura A.1.6 - Apara de rebarbas e sobras de material .82

Figura A.1.7 - Etapa na qual se desenforma a peça final do molde .82

Figura A.1.8 - Embalagem cuidadosa do refletor para o transporte a São Paulo devido à fragilidade do material .83 
Figura A.1.9 - Chegada do refletor parabólico a São Paulo .83

Figura A.1.10 - Cópia em fibra de vidro do molde parabólico da UFPB .84

Figura A.1.11 - Tintas adquiridas para testes de refletância direcional .85

Figura A.1.12 - Amostras de película refletiva autoadesiva e de peça plástica submetida à técnica de metalização a alto vácuo .85

Figura A.1.13 - Espectrofotômetro UV-3101PC utilizado para teste dos revestimentos (detalhe para a configuração de sua câmara de teste) 86

Figura A.1.14 - Espectrômetro portátil DEVICE SSR-ER utilizado para teste dos revestimentos .87

Figura A.1.15 - Procedimento de teste para determinação da refletância dos revestimentos .87

Figura A.1.16 - Refletor parabólico revestido com película autoadesiva refletora....89 Figura A.1.17 - Suporte móvel e destaque para a adaptação feita no refletor para sua fixação no suporte .89

Figura A.2.1 - Resultado da instalação de divisórias para o confinamento do simulador solar .90

Figura A.2.2 - Destaque para os vidros das divisórias revestidos com película Insulfilm $\AA^{8}$ 91

Figura A.2.3 - Destaque para o exaustor axial instalado no espaço confinado do simulador solar 91

Figura A.2.4 - Nova instalação elétrica para alimentar os equipamentos adquiridos92 Figura A.3.1 - Representação esquemática do balanço térmico da cavidade receptora - adaptado de Ribas (2016) .93

Figura A.3.2 - Representação do balanço térmico da cavidade receptora por analogia elétrica - adaptado de Ribas (2016).... .94 
Figura A.3.3 - Dimensões consideradas na modelagem do balanço térmico da cavidade receptora - adaptado de Ribas (2016) ................................................95 Figura A.3.4 - Diagrama quantitativo de perdas térmicas estimadas na cavidade

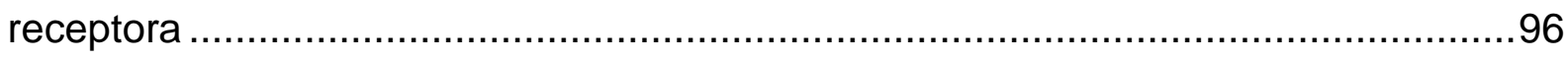




\section{LISTA DE TABELAS}

Tabela 2.1 - Desempenho dos simuladores solares de alto fluxo utilizando arranjos de lâmpadas - adaptado de Dong et al (2012) .28

Tabela 3.1 - Características estimadas para o novo simulador solar 41 Tabela 6.1 - Resumo dos parâmetros medidos e calculados para regime permanente no teste 1 .67

Tabela 6.2 - Resumo dos parâmetros medidos e calculados para regime permanente no teste 2 69

Tabela 7.1 - Parâmetros do simulador solar (estimados X medidos) .72

Tabela A.1.1 - Resultados do teste de refletância dos revestimentos .88 


\section{SUMÁRIO}

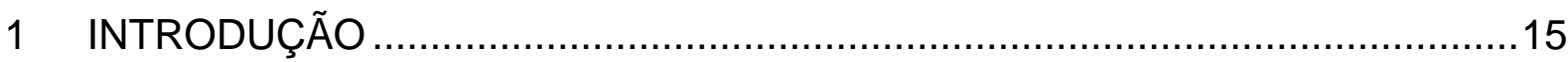

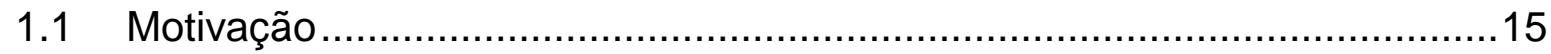

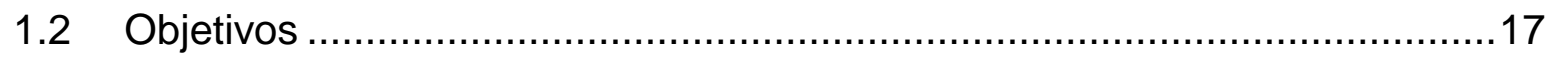

2 REVISÃO BIBLIOGRÁFICA E EMBASAMENTO TEÓRICO …........................18

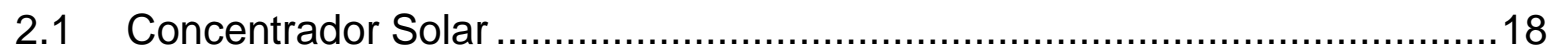

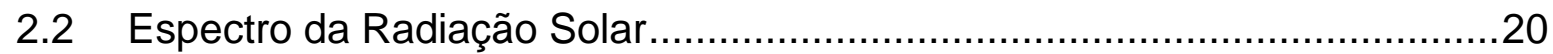

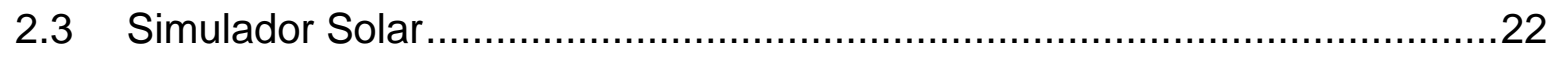

2.4 Principais Aplicações da Energia Heliotérmica ......................................25

2.5 Simuladores Solares de Alto Fluxo em Operação......................................27

2.5.1 Petrasch et al. (2007) - PSI: Paul Scherrer Institute - Suíça ................28

2.5.2 Codd et al. (2010) - MIT: Massachusetts Institute of Technology Estados Unidos

2.5.3 Alxneit e Dibowski (2011) - DLR: Institute of Solar Research Alemanha .30

2.5.4 Erickson B.M. (2012) - UF: University of Florida - Estados Unidos ......31

2.5.5 Sarwar et al. (2014) - Texas A\&M University at Qatar - Qatar .............32

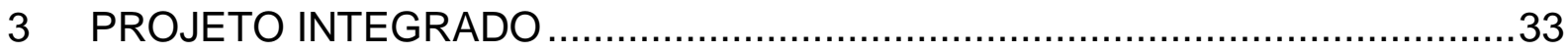

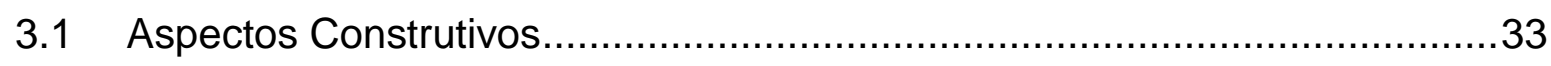

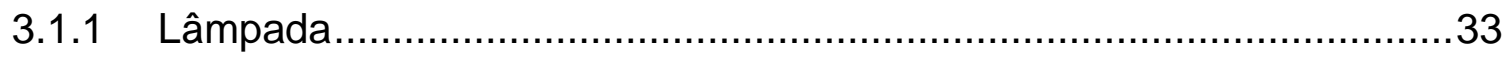

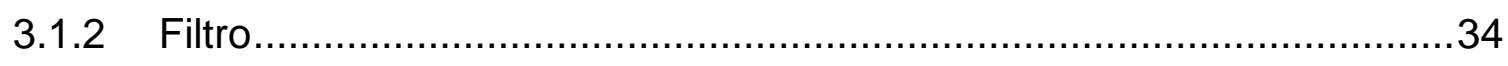

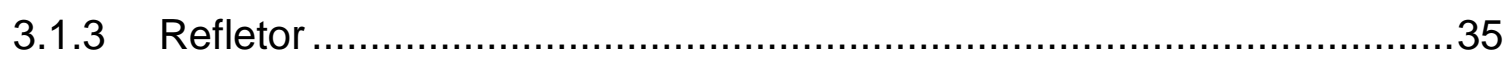


3.1.4 Sistema de resfriamento

3.1.5 Arranjo ótico

3.1.6 Receptor .38

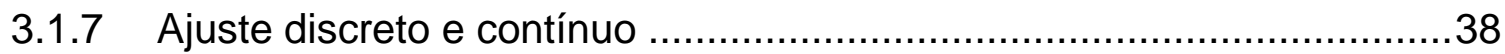

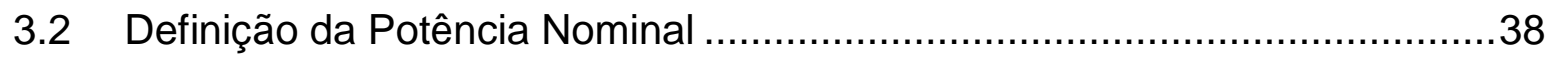

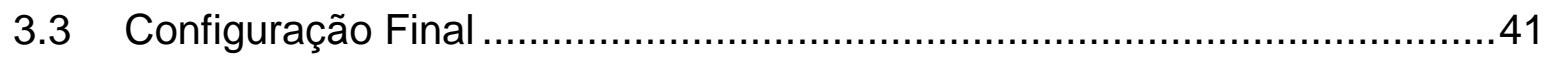

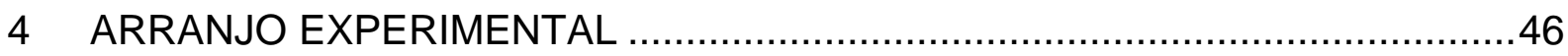

4.1 Descrição do Sistema - Visão Geral ..................................................46

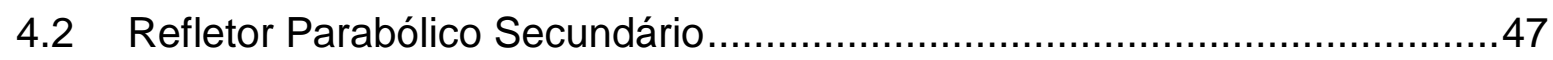

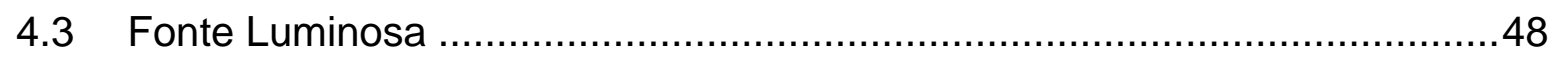

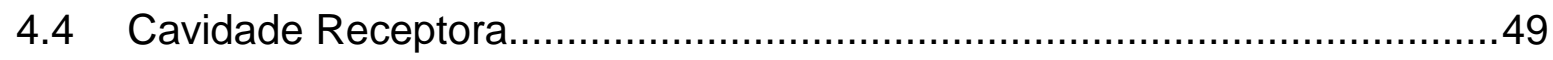

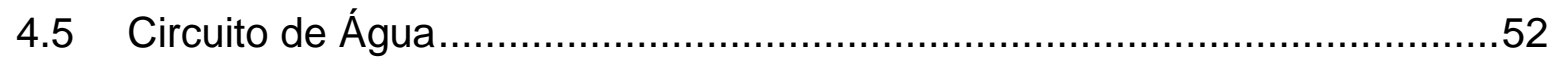

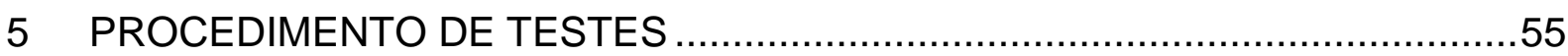

5.1 Avaliação do Perfil Espectral da Lâmpada ...............................................55

5.2 Avaliação do Fluxo de Calor no Foco do Concentrador ..............................58

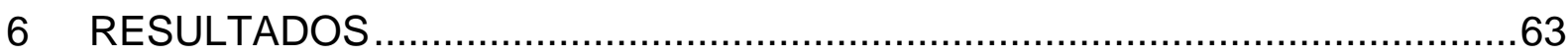

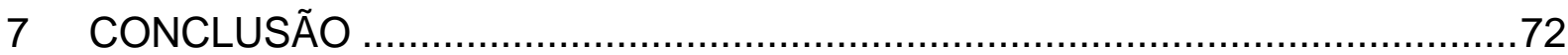

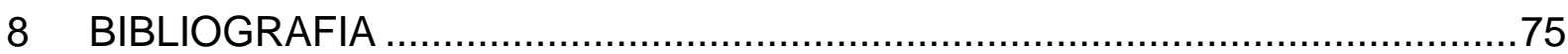

A.1 Fabricação do Refletor Parabólico Secundário .............................................79

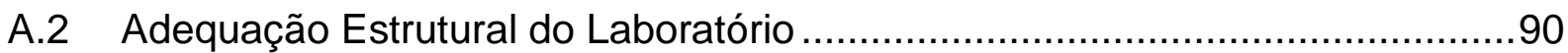

A.3 Balanço Térmico por Analogia Elétrica da Cavidade Receptora .....................93

A.4 Análise e Propagação de Incertezas ......................................................... 


\section{INTRODUÇÃO}

\subsection{Motivação}

A radiação solar é certamente a fonte de energia livre de carbono mais abundante no planeta. Recobrindo-se apenas $0,1 \%$ da superfície terrestre com coletores solares operando com uma eficiência de $20 \%$ é possível se obter energia para suprir a demanda atual do planeta $\left(\sim 1,2 \times 10^{14} \mathrm{kWh} / \mathrm{ano}\right)$. Além disso, a energia proveniente do Sol é ilimitada e ecologicamente inofensiva (Steinfeld e Meier, 2004).

Os principais empecilhos para o aproveitamento da radiação solar são a forma diluída na qual ela é encontrada (no máximo $1 \mathrm{~kW} / \mathrm{m}^{2}$ ), a sua característica intermitente ao longo do dia e das condições climáticas, bem como da sua distribuição irregular ao longo do globo e das estações do ano, não acompanhando a variação diária e sazonal da demanda energética. Dessa forma, torna-se necessário armazenar esta energia para utilizá-la em situações de baixa ou nenhuma incidência de radiação solar.

Estas dificuldades podem ser superadas por meio da conversão da energia do Sol em outras formas de energia, permitindo o transporte e armazenamento de maneira conveniente. Uma aplicação promissora é a conversão da energia solar em energia química pela geração de combustíveis solares. Estes combustíveis, sobretudo o gás hidrogênio, são assim chamados porque são gerados através de uma transformação química endotérmica promovida pela absorção da radiação solar concentrada, armazenando esta energia na forma de ligações químicas.

Os combustíveis solares podem ser utilizados para enriquecer combustíveis fósseis, queimados para gerar calor, assim como processados em trabalho mecânico ou elétrico de turbinas e geradores ou motores de combustão interna, ou ainda usados 
diretamente para gerar eletricidade em células combustíveis e baterias para satisfazer a demanda a qualquer hora e local necessário. O desafio é produzir em larga escala estes combustíveis químicos diretamente a partir da radiação solar, utilizando aparatos robustos, economicamente viáveis e que reduzam os efeitos negativos ao Meio Ambiente.

Apesar dos significativos avanços nas pesquisas voltadas a comprovar novas alternativas para a conversão e armazenamento da energia solar concentrada e de ser evidente a sua importância na matriz energética futura, grande parte desses experimentos ainda não é aplicável em escala comercial e necessita de grandes esforços laboratoriais para desenvolvimento e aperfeiçoamento da tecnologia. Nesse contexto promissor surge a necessidade de um aparato que reproduza artificialmente a radiação solar concentrada de forma controlada e constante: o simulador solar.

Os simuladores solares são de grande importância porque, ao substituírem o Sol por fontes artificiais, como lâmpadas capazes de emitir radiação próxima à solar, eliminam a dependência de fatores naturais como condições do tempo, intermitência e movimento de direção da radiação solar. Assim, eles trazem ao pesquisador a comodidade de realizar testes em pequena escala nos laboratórios, eliminando a necessidade de ir a campo. Isto resulta em economia de tempo e investimentos para realização de experimentos iniciais, o que viabiliza novas linhas de pesquisa e aumenta a chance de descoberta do aparato mais adequado para uso em larga escala. 


\subsection{Objetivos}

O projeto proposto para esta dissertação de Mestrado teve como objetivo geral projetar e construir um simulador solar concentrador na Escola Politécnica da USP para facilitar os estudos sobre aproveitamento da energia solar nesta Instituição. Por tratar-se de um protótipo de escala laboratorial, sua potência térmica não ultrapassa $10 \mathrm{~kW}$.

Como objetivos específicos, foram definidas as seguintes tarefas:

$\checkmark$ Estudar $o$ princípio de funcionamento dos simuladores solares concentradores existentes no mundo;

$\checkmark$ Definir a configuração e a geometria do concentrador mais adequadas para o projeto em questão;

$\checkmark$ Projetar as peças a serem construídas e buscar fornecedores para aquelas a serem adquiridas;

$\checkmark$ Realizar testes para avaliar a qualidade do projeto, a resistência dos componentes e o fator de concentração do aparato. 


\section{REVISÃO BIBLIOGRÁFICA E EMBASAMENTO TEÓRICO}

Este capítulo compreende a revisão bibliográfica e o embasamento teórico, para o posterior desenvolvimento do projeto. Visa-se, com isso, reunir todos os conhecimentos que são pré-requisitos para a compreensão do projeto e sucesso de sua operação.

\subsection{Concentrador Solar}

Os concentradores solares são equipamentos que incluem aparatos óticos com a finalidade de aumentar a densidade de radiação em uma região, já que a energia proveniente do Sol apresenta baixa irradiação (apenas $\sim 1 \mathrm{~kW} / \mathrm{m}^{2}$ ). Estes concentradores solares são compostos por espelhos ou outras películas refletoras responsáveis por direcionar a radiação recebida para um foco, a fim de se obter uma região de radiação intensa onde são obtidas altíssimas temperaturas. O fator de concentração é usualmente medido usando-se como referência a radiação solar e, por isso, este fator (adimensional) é comumente expresso na unidade de "sóis". Um "sol" é definido como sendo $1 \mathrm{~kW} / \mathrm{m}^{2}$.

Os coletores de energia solar são geralmente compostos por um concentrador e um receptor, e podem ser concebidos em diferentes formas geométricas, cada uma com seu fator de concentração associado. Os principais tipos são apresentados na figura abaixo: 
A

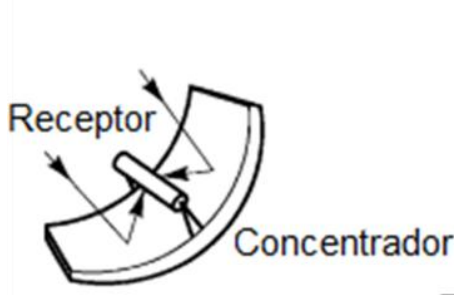

B

Receptor

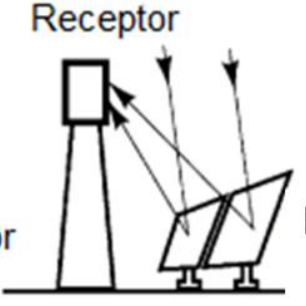

C

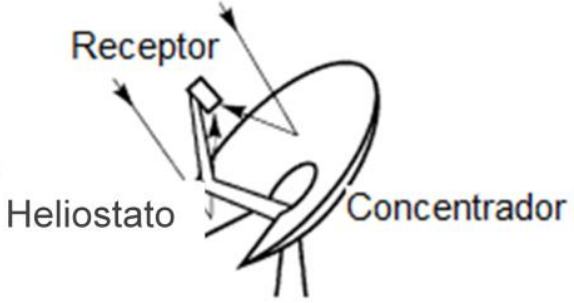

Figura 2.1 - Configuração de concentradores solares (A) Sistema cilindro parabólico (B) Sistema de torre (C) Sistema de disco - adaptado de Steinfeld e Meier (2004)

- Sistema cilindro parabólico (concentração de 30 a 100 sóis) (Steinfeld e Meier, 2004)

Neste caso, a radiação que incide na calha de seção parabólica é direcionada para um cilindro na linha de foco do concentrador.

- Sistema de torre (500 a 5.000 sóis) (Steinfeld e Meier, 2004)

Neste sistema são utilizados espelhos (heliostatos) independentes posicionados de modo que toda a radiação seja refletida para um receptor no alto de uma torre.

- Sistema de disco (1.000 a 10.000 sóis) (Steinfeld e Meier, 2004)

O sistema de disco emprega espelhos na disposição de um paraboloide e o receptor localizado em seu foco recebe toda a radiação.

Os coletores solares de torre são os mais empregados ao redor do mundo já que, apesar desta não ser a geometria mais eficiente, sua facilidade construtiva implica em vantagens financeiras. 


\subsection{Espectro da Radiação Solar}

Segundo Duffie e Beckman (2013), o Sol é um imenso reator nuclear $\left(1,39 \times 10^{9} \mathrm{~m}\right.$ de diâmetro) que emite grande quantidade de energia constantemente. Radiação solar é a designação dada à energia radiante emitida pelo Sol, em particular aquela que é transmitida sob a forma de radiação eletromagnética. A cada ano, 3,8 $\times 10^{12}$ TJ de energia solar atingem a superfície terrestre, ou seja, toda energia que as atividades humanas demandam representa apenas $0,0014 \%$ do total que o Sol fornece. Cerca de metade desta energia é emitida como luz visível e o restante, nas bandas de frequência do infravermelho próximo e da radiação ultravioleta do espectro eletromagnético.

Diz-se que a temperatura efetiva de corpo negro do Sol equivale a $5.777 \mathrm{~K}$, o que significa que esta é a temperatura que um corpo negro teórico apresentaria se radiasse a mesma quantidade de energia que o Sol. Dada a dependência entre o espectro e a temperatura, traduzida na Lei de Planck, a distribuição espectral da luz solar corresponde aproximadamente àquela apresentada por um corpo negro aquecido a 5.777K também, conforme comparação apresentada na Figura 2.2.

Em termos de comprimentos de onda, a radiação solar ocupa uma extensa faixa espectral (100 nm a $3000 \mathrm{~nm}$ ), tendo sua máxima densidade observada em torno dos $550 \mathrm{~nm}$, comprimento de onda que corresponde sensivelmente à luz verdeamarelada. $\mathrm{O}$ trecho mais alongado do espectro tem sua máxima intensidade na banda dos infravermelhos próximos, decaindo lentamente com a diminuição da frequência. Em relação à radiação mais energética, isto é, de comprimento de onda mais curto, apesar da maior parte ser absorvida pela camada de ozônio, parte da radiação ultravioleta ainda atinge a superfície da Terra. 


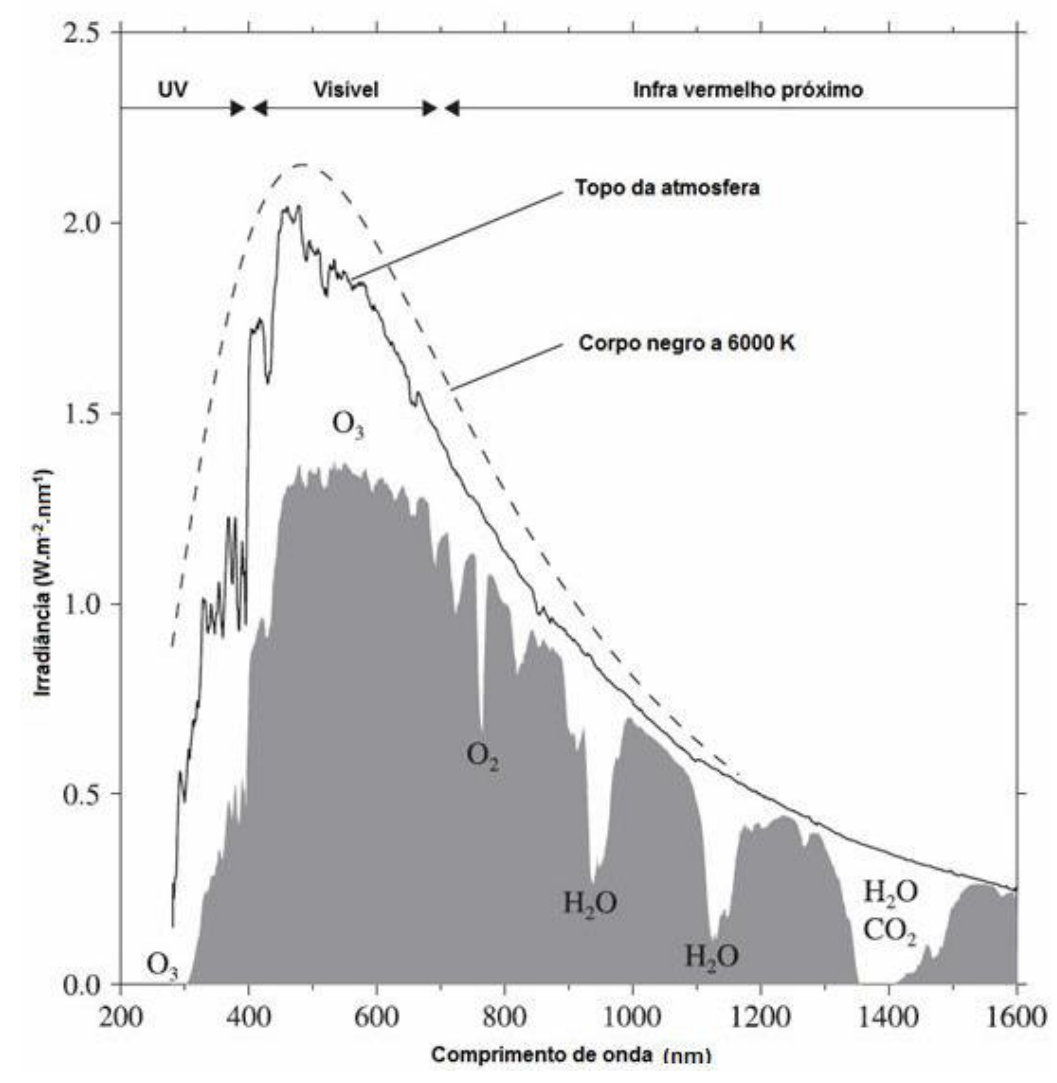

Figura 2.2 - Espectro de irradiância da radiação solar no topo da atmosfera (linha sólida) e ao nível do mar (sombreado) em comparação ao espectro de um corpo negro (linha tracejada) adaptado de Andrews (2010)

A irradiância solar fora da atmosfera é quase constante em toda a órbita da Terra e equivale a $1.367 \mathrm{~W} / \mathrm{m}^{2}$, denominada Constante Solar (Duffie e Beckman, 2013). Embora a radiação extraterrestre possa ser predita com grande assertividade, os níveis de radiação solar em terra são variáveis devido às condições climáticas locais imprevisíveis. Os dados de radiação estimados em projetos e geralmente utilizados em aplicações de engenharia solar são baseados em médias históricas, ou seja, medidas de longo prazo (10 ou mais anos).

Parte da radiação solar extraterrestre consegue atravessar a atmosfera, mas parte é refletida ou espalhada de volta ao espaço. Fração desta radiação que vence a atmosfera é então absorvida pelo ar, gases e vapor de água, outra parcela é dispersa por moléculas de ar, vapor de água, aerossóis e partículas de poeira. A 
parcela de radiação solar que alcança a superfície da Terra sem mudança na direção é chamada radiação direta. A radiação que é refletida em outros objetos (albedo) ou a radiação dispersa que alcança a superfície é chamada de radiação difusa. Esses são os componentes da radiação de interesse para a engenharia solar, porém apenas a radiação direta pode ser concentrada para fins energéticos de mais altas temperaturas, como é o caso deste projeto.

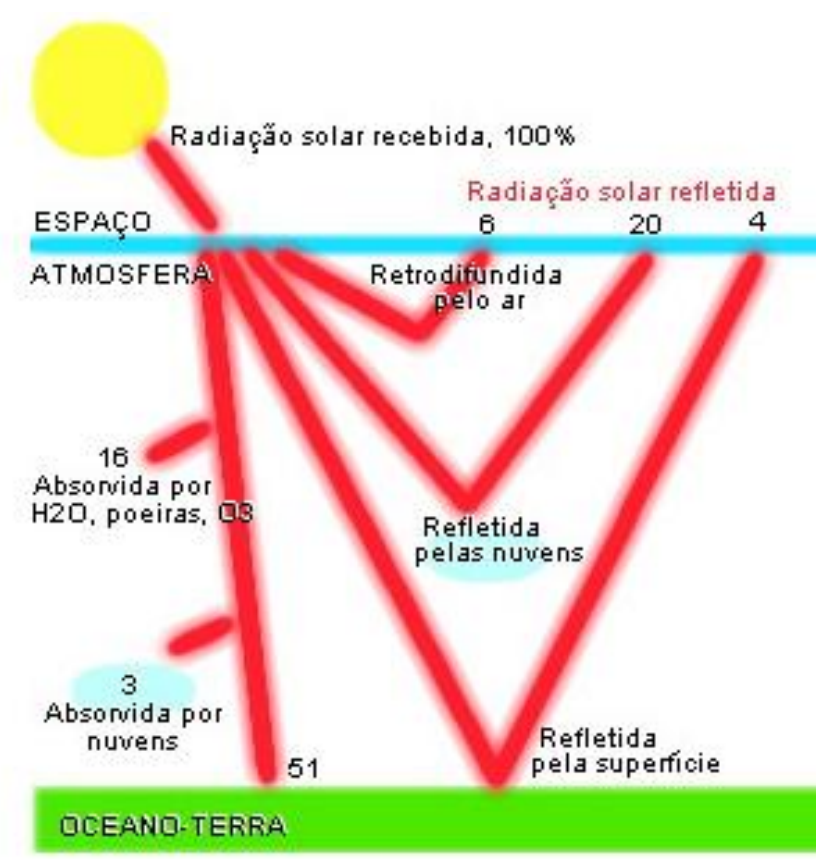

Figura 2.3 - Exemplo de balanço global da radiação solar para uma determinada região adaptado de ClimaGeo: Comunidade de Climatologia (2015)

\subsection{Simulador Solar}

Foram estudados os simuladores solares do tipo "alto-fluxo", empregados no teste de componentes e materiais para aplicações térmicas e termoquímicas a altas temperaturas. Sua forma construtiva tem como objetivo simular a distribuição direcional, espacial e espectral da radiação solar concentrada obtida no plano focal de um concentrador. A fonte de radiação destes simuladores geralmente é constituída por lâmpadas de xenônio ou argônio de alta potência que, associadas a 
refletores óticos de precisão adequada, podem produzir um feixe contínuo de radiação térmica intensa que se aproxima à transferência de calor característica dos sistemas de concentradores solares usuais (Petrash et al, 2007).

O conceito de um simulador solar de alto fluxo é relativamente simples. O aparato deve possuir conjuntos óticos com um perfil emissivo semelhante ao solar e que direcione a sua radiação de forma convergente para uma pequena área de recepção na qual se estabelecerá uma alta densidade de radiação e absorção (Figura 2.4). Atualmente, alguns equipamentos chegam a reproduzir uma concentração de mais de 10.000 sóis. O simulador projetado é composto por um conjunto de lâmpadas de xenônio acopladas a filtros de radiação, refletores e outros subsistemas associados que serão detalhados a seguir.

Diversos simuladores solares de feixes paralelos são utilizados ao redor do mundo para estudos ou testes de certificação de painéis fotovoltaicos e coletores solares comerciais como o disponível no Instituto de Pesquisas Tecnológicas de São Paulo - IPT. Este tipo de equipamento reproduz a irradiação solar terrestre padrão: feixes de luz paralelos e potência incidente de aproximadamente $1 \mathrm{~kW} / \mathrm{m}^{2}$. Simuladores como este não possuem capacidade de concentração.

Já os simuladores solares de alto fluxo (com concentração de radiação) possuem uma aplicação completamente diferente dos anteriores, pois envolvem 0 aproveitamento da energia solar de alta temperatura para ativação de reações endotérmicas já mencionadas anteriormente. Apesar disso, este tipo de simulador é menos difundido devido à sua complexidade construtiva e operacional, apresentando poucos exemplares, mesmo em escala laboratorial; notavelmente nos institutos PSI-Suíça e DLR-Alemanha (Alxneit e Dibowski, 2011). Este contexto 
explicita o grande desafio vencido e o caráter pioneiro em âmbito nacional deste projeto.

A Figura 2.4 ilustra um arranjo ótico formado por dez lâmpadas de xenônio, cada uma associada a um refletor elipsoidal de configuração otimizada. Nota-se que os refletores elipsoidais das dez lâmpadas não precisam ser idênticos, eles podem ser otimizados separadamente para promover um melhor desempenho, como informado por Petrash et al (2007). Esta liberdade pode ser usada para prover um fluxo mais homogêneo no foco, onde se localiza o receptor, ou para ajustar o sistema sob qualquer outro requisito de projeto:

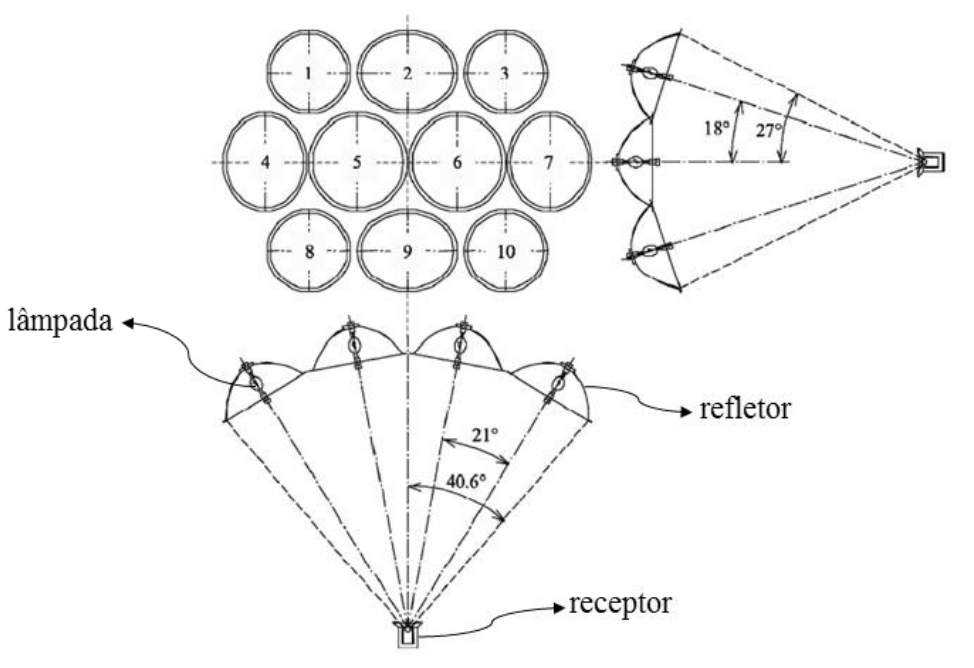

Figura 2.4 - Arranjo ótico formado por dez lâmpadas de xenônio do tipo №3 - adaptado de Petrash et al (2007)

Um exemplar deste tipo de simulador solar foi construído no Laboratório de Tecnologia Solar do Instituto Paul Scherrer (PSI), liderado pelo professor Aldo Steinfeld do Instituto Federal de Tecnologia de Zurique (ETH Zurich). Abaixo, a imagem do arranjo de lâmpadas de alta pressão de xenônio que constituem o simulador solar do ETH, capaz de gerar até 50 kW de energia de radiação: 


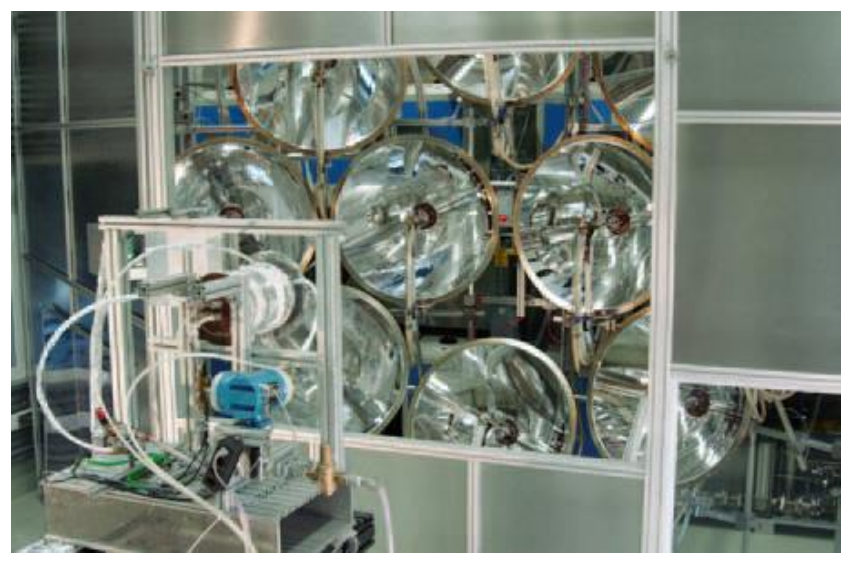

Figura 2.5 - Arranjo experimental de simulador solar - adaptado de Meier e Sattler (2009)

\subsection{Principais Aplicações da Energia Heliotérmica}

A energia heliotérmica, também chamada de energia solar térmica concentrada ou CSP (Concentrated Solar Power) internacionalmente, trata-se da tecnologia capaz de converter a energia da radiação solar em energia térmica e/ou elétrica. Por meio da concentração dos raios solares, temperaturas de $1500^{\circ} \mathrm{C}$ ou mais são atingidas no foco do coletor concentrador, onde um fluido de trabalho é aquecido e a energia solar é convertida em energia térmica; o fluido, que pode ser um vapor ou óleo térmico, pode então ser utilizado diretamente em processos industriais nesta etapa. A conversão final em energia elétrica dá-se no ciclo de potência, onde a expansão do fluido de trabalho é responsável por acionar uma turbina ou máquina a vapor. Um motor de ciclo Stirling também pode ser empregado para a produção de energia eletromecânica através de um gerador acoplado.

Nestes sistemas convencionais de aproveitamento de energia heliotérmica, a característica intermitente da radiação solar ao longo do dia e das condições climáticas ainda representa um grande empecilho, bem como da sua distribuição irregular ao longo do globo e das estações do ano, não acompanhando a variação diária e sazonal da demanda energética. Assim, o armazenamento desta energia de 
forma viável, técnica e economicamente, ainda representa um desafio a ser superado.

Atualmente, a energia heliotérmica pode ser armazenada em cada uma de suas etapas de conversão: como energia térmica, através de reservatórios de fluido de trabalho aquecido ou sais fundidos, ou como energia elétrica, por meio de baterias. Uma terceira forma de armazenamento, porém, vem se mostrando muito promissora e vem despertando a atenção de muitos pesquisadores: a conversão da energia solar em energia química por meio dos combustíveis solares. Estes combustíveis, sobretudo o gás hidrogênio, são assim chamados porque são gerados através de uma transformação química endotérmica promovida pelo calor da radiação solar concentrada, armazenando esta energia na forma de ligações químicas.

Como já mencionado anteriormente, os combustíveis solares podem ser utilizados para enriquecer combustíveis fósseis, queimados para gerar calor, assim como processados em trabalho mecânico ou elétrico de turbinas e geradores ou motores de combustão interna, ou ainda usados diretamente para gerar eletricidade em células combustíveis e baterias para satisfazer a demanda a qualquer hora e local necessário. O desafio é produzir em larga escala estes combustíveis químicos diretamente a partir da radiação solar, utilizando aparatos robustos, economicamente viáveis e que reduzam os efeitos negativos ao Meio Ambiente.

Outras alternativas também são estudadas ao redor do mundo para a conversão e armazenamento da energia solar. Esta energia concentrada pode ser empregada em uma gama farta de aplicações em que são necessárias altas temperaturas para a ativação de processos químicos endotérmicos, energia esta que atualmente provém majoritariamente de fontes termelétricas pelo mundo. Além do apelo 
ambiental relacionado à redução de emissões gasosas e de poluentes, esta é uma tecnologia de grande potencial econômico uma vez que substitui combustíveis tradicionais limitados por uma fonte energética inesgotável: o Sol. A extração de metais de seus óxidos (em especial do zinco), a síntese de fulerenos (forma alotrópica do carbono de grande aplicação da indústria química) e do carbono fibroso catalítico (CFC), a decomposição térmica do carbonato de cálcio em óxido de cálcio (cal), a pirólise térmica e a gaseificação de resíduos sólidos são alguns exemplos dado por Steinfeld e Meier (2004).

\subsection{Simuladores Solares de Alto Fluxo em Operação}

Este projeto tem como foco principal o estudo dos simuladores solares do tipo alto fluxo, empregados no teste de componentes e materiais para aplicações térmicas e termoquímicas a altas temperaturas (ativação de reações endotérmicas, por exemplo). Sua forma construtiva tem como objetivo simular a distribuição direcional, espacial e espectral da radiação solar concentrada obtida no plano focal de um concentrador.

Como já mencionado anteriormente, este tipo de simulador é menos difundido devido à sua complexidade construtiva e operacional, apresentando poucos exemplares, mesmo em escala laboratorial. Nesta seção serão apresentados brevemente os simuladores solares de alto fluxo em operação pelo mundo e suas principais especificações técnicas.

De acordo com Dong et al (2012), todos os simuladores solares de alto fluxo que haviam sido divulgados em domínio público até então e utilizavam arranjos de lâmpadas como fonte de radiação foram listados na Tabela 2.1. É possível observar 
que grande parte destes projetos optou pelo uso de múltiplas lâmpadas de xenônio, apesar do máximo fluxo de calor radiativo diferir bastante entre os simuladores solares estudados.

Tabela 2.1 - Desempenho dos simuladores solares de alto fluxo utilizando arranjos de lâmpadas - adaptado de Dong et al (2012)

\begin{tabular}{|c|c|c|c|c|c|c|c|}
\hline $\begin{array}{l}\text { Simulador } \\
\text { Solar }\end{array}$ & $\begin{array}{l}\text { Tipo de } \\
\text { Lâmpada }\end{array}$ & $\begin{array}{c}\text { Potência } \\
\text { Elétrica } \\
\text { (kW/lâmp.) }\end{array}$ & $\begin{array}{c}\text { Número } \\
\text { de } \\
\text { Lâmpadas }\end{array}$ & $\begin{array}{c}\text { Máximo Fluxo } \\
\text { de Calor } \\
\text { Radiativo } \\
\left(\mathrm{MW} / \mathrm{m}^{2}\right)\end{array}$ & $\begin{array}{l}\text { Média do } \\
\text { Fluxo de } \\
\text { Calor } \\
\text { Radiativo } \\
\left(\mathrm{MW} / \mathrm{m}^{2}\right)\end{array}$ & $\begin{array}{c}\text { Potência } \\
\text { Radiativa } \\
\text { Total } \\
\text { (kW) }\end{array}$ & $\begin{array}{c}\text { Custo do } \\
\text { Simulador } \\
\text { US\$/(kW/m²) } \\
\text { (US\$/kW) }\end{array}$ \\
\hline $\begin{array}{c}\text { Petrasch } \\
\text { et al } \\
(2007)\end{array}$ & Xenônio & 15 & 10 & 11 & 6,8 & 50 & \\
\hline $\begin{array}{l}\text { Codd et } \\
\text { al. (2010) }\end{array}$ & $\begin{array}{c}\text { Halogeneto } \\
\text { de Metal }\end{array}$ & 1,5 & 7 & 0,06 & 0,045 & 5,1 & $\begin{array}{c}167 \\
2000\end{array}$ \\
\hline $\begin{array}{l}\text { Turner and } \\
\text { Ash (1994) }\end{array}$ & $\begin{array}{l}\text { Quartz de } \\
\text { Tungstênio }\end{array}$ & 0,74 & 6 & 0,04 & 0,025 & 3,56 & \\
\hline $\begin{array}{l}\text { Craig } \\
(2010)\end{array}$ & Xenônio & 4,229 & 1 & 10 & & 4 & \\
\hline $\begin{array}{c}\text { Alxneit e } \\
\text { Dibowski } \\
(2011)\end{array}$ & Xenônio & 6 & 6 & & & & \\
\hline $\begin{array}{l}\text { Li et al } \\
\text { (2011) }\end{array}$ & Xenônio & 7 & $12^{1}$ & $\begin{array}{c}4,27 \\
(0,326 / \text { lâmpada })\end{array}$ & & 12,55 & \\
\hline
\end{tabular}

Li et al. idealizou um simulador solar de 12 lâmpadas, porém os resultados experimentais foram divulgados para uma única lâmpada.

\subsubsection{Petrasch et al. (2007) - PSI: Paul Scherrer Institute - Suíça}

O simulador solar de alto fluxo do Instituto Paul Scherrer foi o pioneiro no uso de lâmpadas de xenônio para este fim. Ele é capaz de fornecer até $50 \mathrm{~kW}$ de potência com picos de fluxo radiativo excedendo 11.000 sóis de concentração. O aparato é formado por um arranjo de 10 lâmpadas de xenônio, cada uma acoplada a um refletor especular elipsoidal, com focos coincidentes, conforme Figura 2.6. As medidas obtidas por calorímetros indicam um fluxo médio de $6.800 \mathrm{~kW} / \mathrm{m}^{2}$ sobre um alvo circular de $60 \mathrm{~mm}$ de diâmetro, o que corresponde a temperaturas de estagnação acima de $3.300 \mathrm{~K}$. 


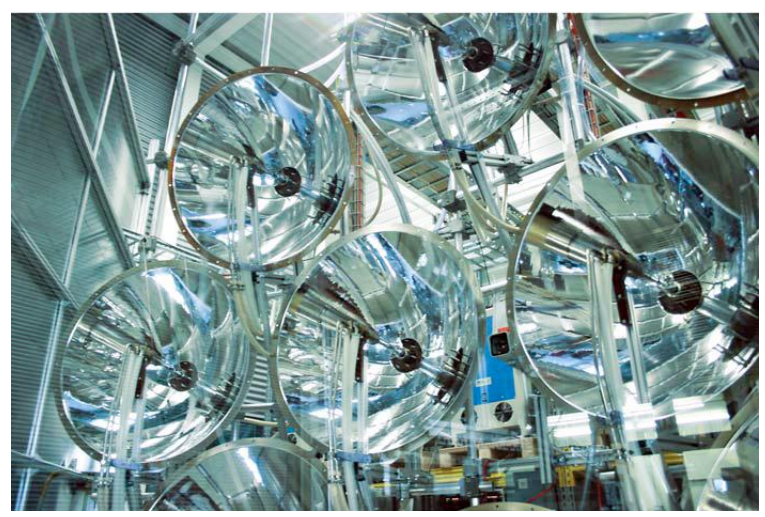

Figura 2.6 - Simulador solar de alto fluxo do PSI (Petrash et al, 2007)

2.5.2 Codd et al. (2010) - MIT: Massachusetts Institute of Technology - Estados Unidos

O projeto deste simulador solar apresentou uma configuração distinta que priorizou o custo de fabricação. Sete lâmpadas de halogeneto de metal de $1.500 \mathrm{~W}$, geralmente utilizadas na iluminação externa de estádios, foram usadas como fonte luminosa para simular a potência solar concentrada por heliostatos. A radiação desta fonte é satisfatoriamente próxima da radiação solar, porém as lâmpadas de halogeneto de metal sem filtro apresentam picos de irradiância entre 800 e 1.000 nm, representando um ganho adicional de 5\% na energia medida na saída se comparada com a irradiância solar terrestre sobre a mesma faixa de comprimento de onda. Com o uso de um concentrador secundário cônico, fluxos de aproximadamente $60 \mathrm{~kW} / \mathrm{m}^{2}$ (60 sóis) pico e $45 \mathrm{~kW} / \mathrm{m}^{2}$ (45 sóis) médios foram alcançados através de uma saída com abertura de $30 \mathrm{~cm}$ de diâmetro. $\mathrm{O}$ uso de componentes estruturais, elétricos e luminosos de prateleira garantiu um custo de fabricação abaixo de $\$ 10.000,00$. O resultado final da construção deste simulador solar concentrador com lâmpadas de halogeneto de metal é apresentado na Figura 2.7: 


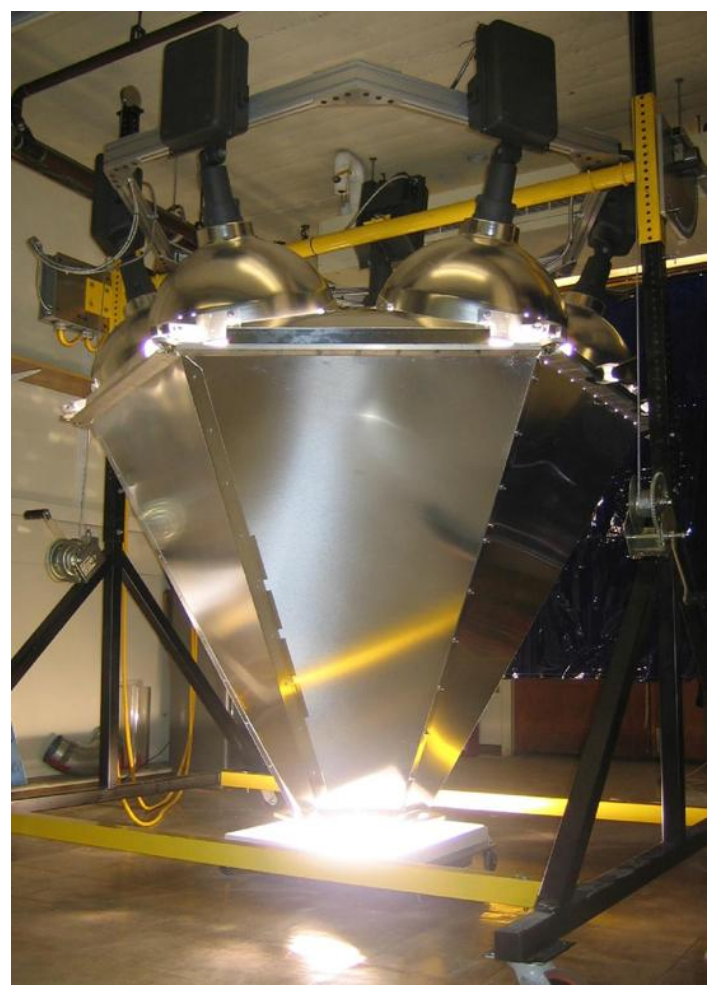

Figura 2.7 - Simulador solar concentrador do MIT - adaptado de Codd et al (2010)

2.5.3 Alxneit e Dibowski (2011) - DLR: Institute of Solar Research - Alemanha O simulador solar de alto fluxo do DLR baseou-se no projeto do instituto PSI, e por isso apresenta muitas semelhanças em relação ao aparato detalhado na seção anterior. Neste simulador, 6 lâmpadas de xenônio de 6 kW (OSRAM 6.000 W/HSLA OFR) foram acopladas a refletores elipsoidais, conforme Figura 2.8. Diferentemente das lâmpadas de xenônio de $15 \mathrm{~kW}$ do PSI que necessitam ser resfriadas a água, as lâmpadas do DLR podem ser resfriadas apenas a ar, o que reduz drasticamente a complexidade deste sistema. A potência radiativa de $20 \mathrm{~kW}$ é direcionada à um alvo de área aproximada de $100 \mathrm{~cm}^{2}$ a uma distância de $3 \mathrm{~m}$, fornecendo uma irradiância maior que $4,1 \mathrm{MW} / \mathrm{m}^{2}$. 


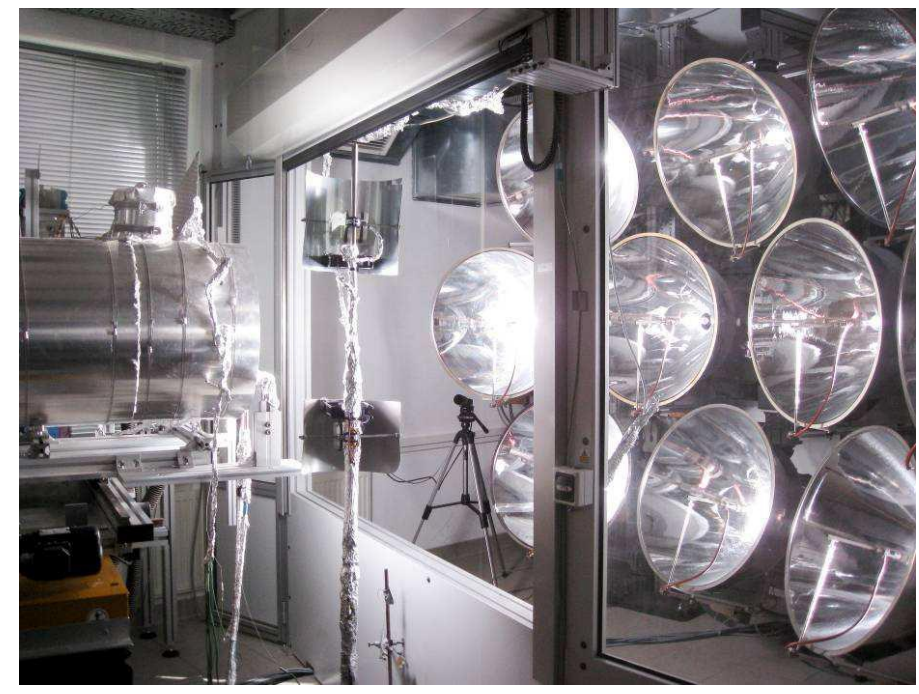

Figura 2.8 - Simulador solar do DLR em operação (Alxneit e Dibowski, 2011)

\subsubsection{Erickson B.M. (2012) - UF: University of Florida - Estados Unidos}

O projeto deste simulador solar foi trazido diretamente da Europa por Hirsch \& Petrasch e adaptado aos Estados Unidos, o que gerou até a necessidade de um transformador para a fonte de energia do equipamento. Trata-se de um modelo constituído por 7 conjuntos formados por lâmpadas de xenônio associadas a refletores elipsoidais e resfriadas a ar. Um conjunto é destacado na Figura 2.9:
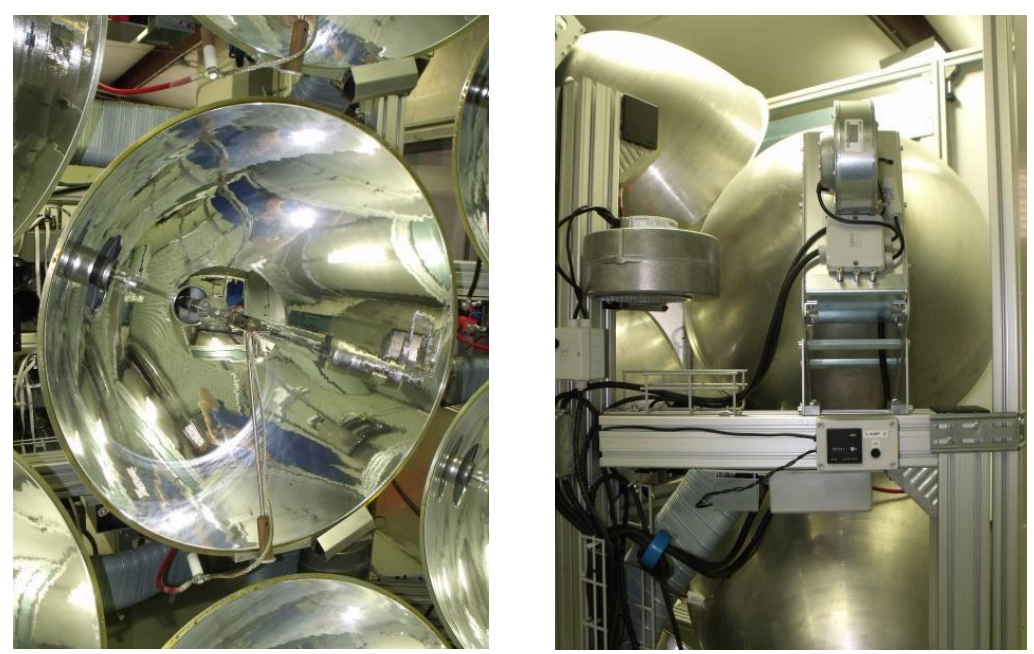

Figura 2.9 - Um dos conjuntos formados por lâmpada e refletor (Erickson, 2012) 
2.5.5 Sarwar et al. (2014) - Texas A\&M University at Qatar - Qatar

O simulador solar de alto fluxo do Laboratório de Pesquisas sobre Energias Sustentáveis da Universidade do Qatar (SER Laboratory - Texas A\&M University at Qatar) é o modelo mais recentemente divulgado nos fóruns científicos. Os próprios autores citam todos os demais projetos mencionados nesta seção em sua revisão bibliográfica, o que leva a crer que o modelo pode ser considerado uma versão otimizada. Este simulador solar apresenta potência radiativa total de $7 \mathrm{~kW}$, fornecida por lâmpadas de xenônio acopladas individualmente a refletores elipsoidais e resfriadas a ar. As principais inovações do projeto são o uso de um filtro de calor dicroica, o painel de controle acoplado e o mecanismo de movimentação individual das lâmpadas que permite o ajuste de foco nos eixos ótico, horizontal e vertical, como se observa na Figura 2.10:

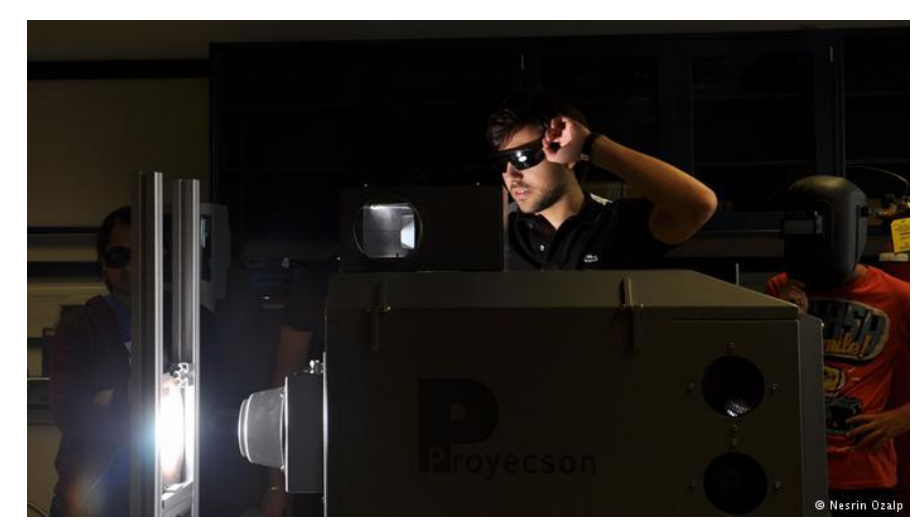

Figura 2.10 - Simulador solar do SER em operação - adaptado de SER Laboratory: Texas A\&M University at Qatar (2016) 


\section{PROJETO INTEGRADO}

O projeto integrado constitui-se da etapa de concepção do aparato, ou seja, definição de todos os parâmetros essenciais para o início da etapa de construção propriamente dita. Dimensão final do aparato, tipo de lâmpada a ser utilizada e tipos de materiais foram definidos neste período, juntamente com o projeto conceitual em software CAD (Computer-Aided Design) do protótipo. Além disso, esta seção inclui também estimativas de saída do simulador solar construído.

\subsection{Aspectos Construtivos}

Nesta seção serão detalhados os subsistemas que compõem os simuladores solares estudados no Capítulo 2, e que representam as alternativas levantadas para a concepção do projeto final.

\subsubsection{Lâmpada}

A lâmpada corresponde à peça principal de um simulador solar, pois ela é a responsável por simular a radiação do Sol como a fonte de radiação térmica para as pesquisas em escala laboratorial. O perfil espectral do Sol se assemelha à emissão teórica de um corpo negro a $5.777 \mathrm{~K}$, sendo esta a característica a ser reproduzida pelo conjunto ótico neste tipo de aplicação.

Este papel é bem desempenhado pelas lâmpadas de arco de xenônio que possuem temperatura de cor (propriedade que indica a temperatura que um corpo negro ideal estaria para emitir radiação equivalente à observada) de aproximadamente $6.000 \mathrm{~K}$. Este tipo de lâmpada é composto por um bulbo de vidro de quartzo fundido 
preenchido com gás xenônio ionizado a alta pressão e dois eletrodos de tungstênio separados por alguns milímetros. Quando acionadas por eletricidade, formam um arco voltaico que emite luz de extrema intensidade e simulam o Sol com satisfatória precisão, sendo utilizadas muitas vezes para este fim. A Figura 3.1 mostra um modelo de lâmpada de xenônio e seu o perfil emissivo.
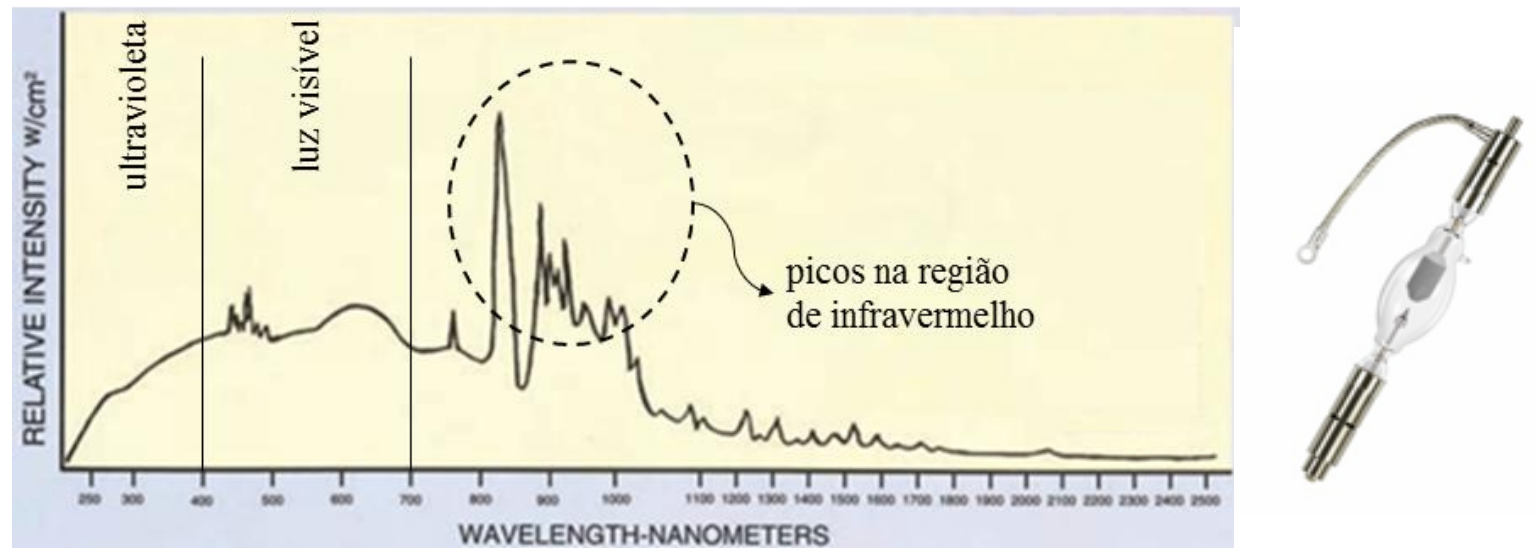

Figura 3.1 - Lâmpada de xenônio e sua distribuição espectral de potência emissiva radiativa adaptado de Superior Quartz Products Inc. (consulta em 2013)

\subsubsection{Filtro}

A função do filtro é ajustar a curva emissiva da lâmpada de xenônio, eliminando os picos de radiação indesejáveis observados em comprimentos de onda na região do infravermelho (Figura 3.1). Este ajuste aproxima ainda mais a irradiação desta lâmpada a solar.

A transmitância (fração da luz incidente que atravessa a matéria) é uma propriedade espectral do material, ou seja, um mesmo componente pode ser quase transparente para alguns comprimentos de onda e mais opaco para certas faixas de frequência. Explorando esta propriedade, os filtros aplicados às lâmpadas se constituem de películas utilizadas para redefinir o perfil de irradiação do conjunto. O processo de 
escolha dos filtros segue a lógica da Figura 3.2, onde diferentes conjuntos de filtros são aplicados até se obter uma configuração ótima.
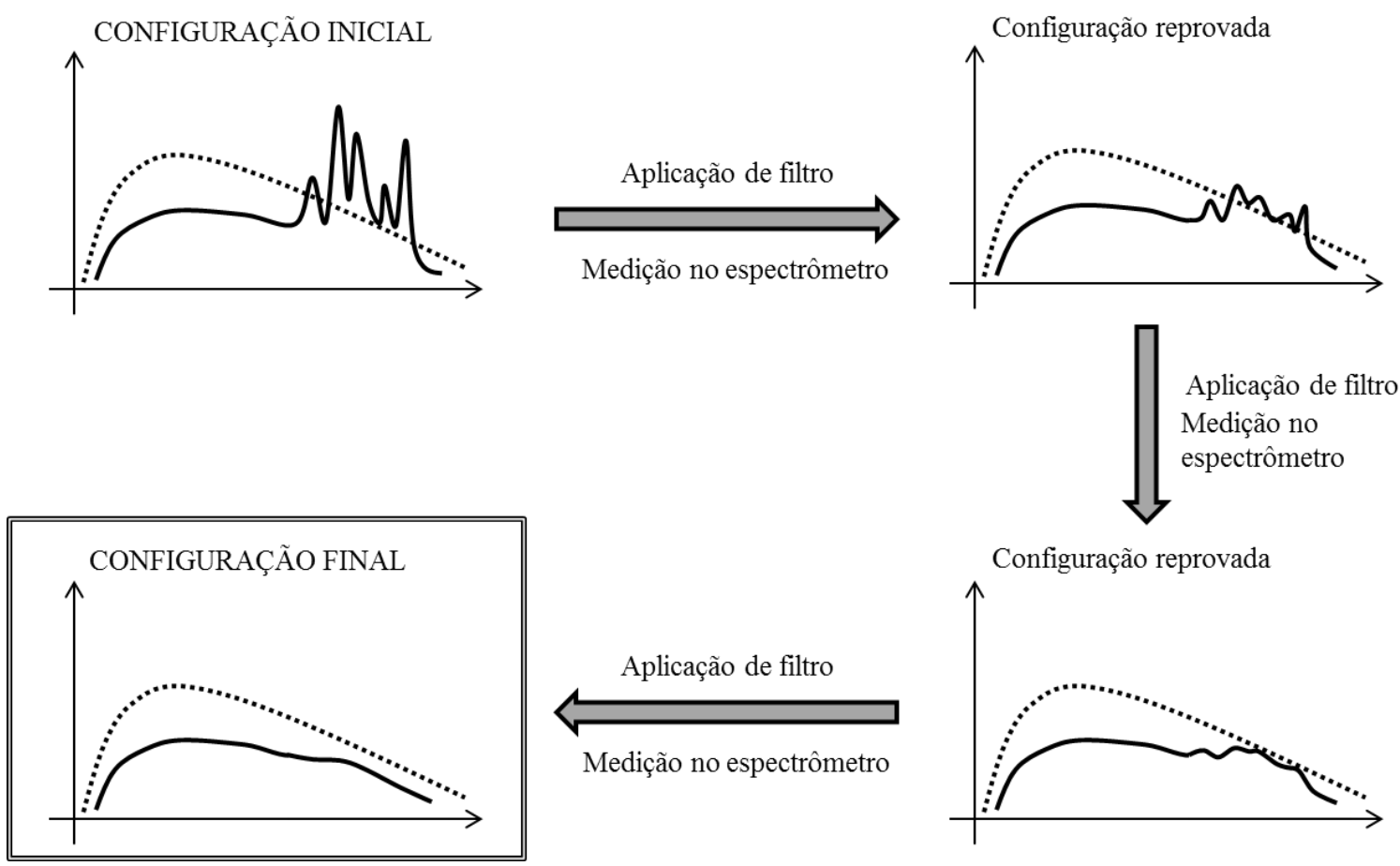

Figura 3.2 - Processo iterativo de aplicação e avaliação dos conjuntos de filtros

\subsubsection{Refletor}

Os refletores são os equipamentos responsáveis por direcionar a radiação proveniente do conjunto lâmpada-filtro para o ponto-alvo especificado no projeto.

No caso da utilização de refletores individuais para cada lâmpada, a escolha de uma geometria elipsoidal é, geralmente, a opção mais adequada. Um elipsoide garante o direcionamento do feixe de radiação da lâmpada para o receptor com apenas uma reflexão. Isto é possível, pois um elipsoide possui dois focos geométricos e tem também a característica de que um raio que parte de um dos focos e atinge sua superfície é refletido para o outro foco. Sendo assim, bastam o emprego de refletores elipsoidais de material de alta refletância e o posicionamento da lâmpada 
e do receptor em cada um dos focos para se garantir uma concentração efetiva. Como a emissão da lâmpada não é exatamente pontual, são admitidos alguns desvios.

Já no caso da utilização de um único refletor secundário para o conjunto de lâmpadas, opta-se por uma geometria parabólica, capaz de concentrar os feixes de raios paralelos provenientes das fontes em um ponto devido a sua característica de foco geométrico único; neste ponto focal deve-se posicionar o receptor.

O processo mais indicado para a confecção dos refletores é conhecido como repuxo (processo utilizado na fabricação de panelas) (Petrash et al, 2007). Como mostrado na Figura 3.3, neste processo, uma lâmina de metal é exposta a alta rotação e é empurrada contra um molde.
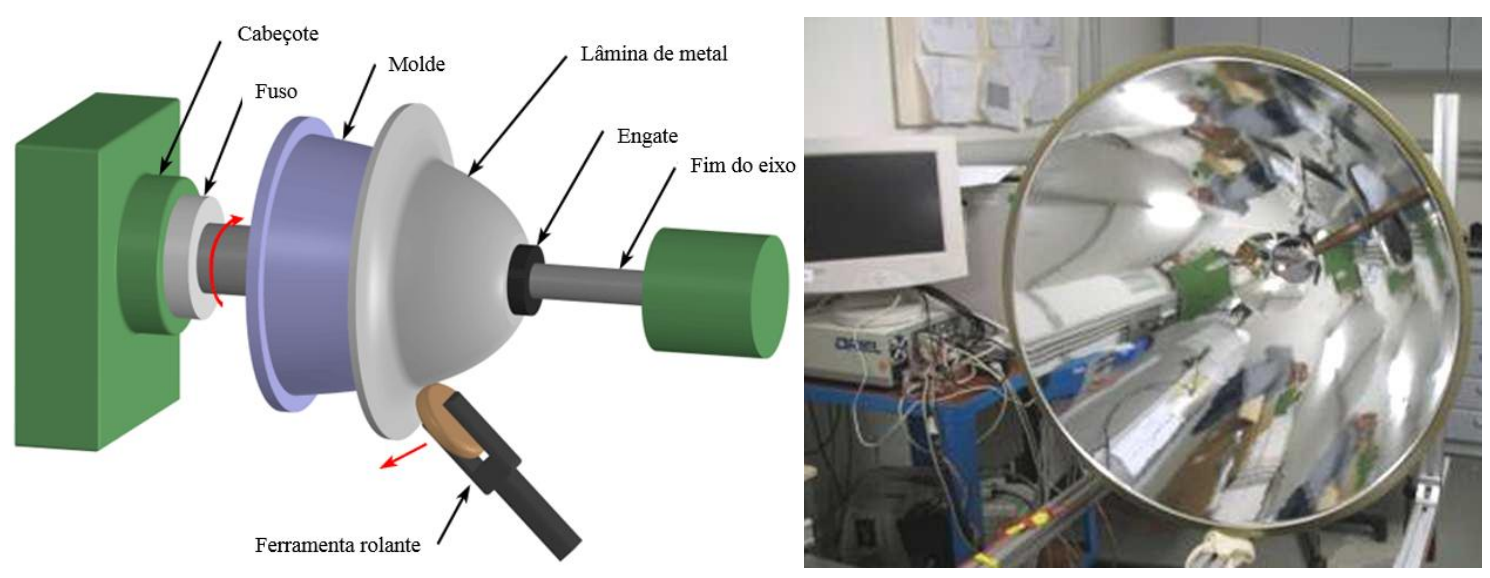

Figura 3.3 - Processo de repuxo para fabricação dos refletores (esquerda) e modelo de um refletor (direita) - adaptado de Alxneit e Dibowski (2011)

Visando aprimorar a refletância destes aparatos, pode ser aplicado um revestimento interno de óxido de alumínio (alumina $-\mathrm{Al}_{2} \mathrm{O}_{3}$ ), dióxido de titânio (anatásio) ou prata. 


\subsubsection{Sistema de resfriamento}

Devido à baixa eficiência elétrica prevista em um simulador solar, a potência elétrica consumida é alta, tornando a temperatura de operação da lâmpada elevada. Isto é indesejável já que pode interferir no perfil de radiação do conjunto e pôr em risco a integridade do equipamento, já que a alta temperatura altera a pressão interna do bulbo da lâmpada, que pode se danificar e até explodir.

Como a convecção natural é insuficiente para o resfriamento das lâmpadas, faz-se necessário o projeto de um sistema eficiente de resfriamento que assegure que a temperatura da fonte luminosa não atingirá $250{ }^{\circ} \mathrm{C}$, valor fornecido pelo fabricante (Superior Quartz Products Inc.). Os sistemas mais comuns são o resfriamento a ar e o resfriamento a água. O resfriamento a ar é consideravelmente mais simples quanto ao projeto, à instalação e à operação; entretanto, ele não é indicado para lâmpadas de potência muito elevada.

\subsubsection{Arranjo ótico}

A elevação da potência irradiante no plano-receptor é obtida através do aumento do número de lâmpadas do simulador solar, desde que estas sejam dispostas de maneira otimizada para garantir uniformidade e simetria radial no plano focal do

receptor. É possível analisar a qualidade de concentração do refletor projetado e avaliar o sucesso da ampliação da potência através do uso de múltiplas lâmpadas. 


\subsubsection{Receptor}

O simulador solar visa atender às necessidades de uma farta gama de experimentos que se baseiem na utilização da energia concentrada do Sol para fins termoquímicos. Desta forma, a cavidade receptora (ou reator) deve ser projetada para a aplicação específica do estudo. Sendo assim, o aparato do simulador solar é versátil ao possuir uma estrutura capaz de acomodar diferentes tipos de cavidade.

\subsubsection{Ajuste discreto e contínuo}

Apesar de o simulador solar possuir sua potência nominal, ele deve ser capaz de ajustar a energia fornecida conforme a demanda térmica de cada experimento. Esta variação deve ser disponibilizada por ajustes discreto e contínuo. O primeiro é obtido pelo simples desligamento de uma ou mais lâmpadas para a obtenção de potências inferiores. O último é um pouco mais complexo e consiste no controle analógico da potência de cada uma das lâmpadas para seleções mais precisas e, principalmente, para ajustes finos durante um ensaio, podendo ser acionada manualmente ou mesmo automaticamente através de sensores e acionadores.

\subsection{Definição da Potência Nominal}

A determinação da potência máxima de radiação térmica e da taxa de concentração no plano do receptor do simulador solar de alto fluxo proposto foi extraída da sinergia entre três diferentes fatores.

Primeiramente, foi preciso levar em conta a demanda atual de radiação dos experimentos em desenvolvimento no laboratório, permitindo uma margem para 
estudos futuros com necessidade de parâmetros mais elevados. O laboratório SISEA já apresenta estudos teóricos que envolvem a reforma de metano, a gaseificação de biomassa e o aquecimento de óleo para um ciclo Rankine através da energia concentrada do Sol. Desta forma, espera-se que o simulador projetado atenda as especificações de projetos destes estudos.

Além disso, foi preciso levar em conta a infraestrutura atualmente encontrada no laboratório SISEA no que se refere a espaço físico e potência elétrica disponíveis, dentre outros.

Por fim, levou-se em conta o aspecto financeiro, de modo a garantir que o retorno científico fosse compatível com o orçamento, tendo em vista o pioneirismo deste tipo de equipamento no país e o grande interesse previsto para o seu uso.

A diferença entre a potência elétrica consumida pelas lâmpadas e a potência térmica irradiante no receptor se dá devido à eficiência total do aparato. Fatores de correção são aplicados devido à eficiência elétrica das lâmpadas, à refletividade dos refletores e, principalmente, à eficiência de concentração. Este último fator é complexo pois é bastante sensível à área considerada para o receptor, ou seja, se considerada uma área mais restrita, a eficiência naturalmente será menor do que se admitida uma área maior. Em uma pequena área, a potência total irradiante é menor, porém a concentração de energia (potência média) é muito maior; dessa forma, é preciso avaliar qual o parâmetro de maior interesse em cada projeto. Esta relação é apresentada no gráfico abaixo referente ao simulador do PSI e publicada em Petrash et al (2007): 


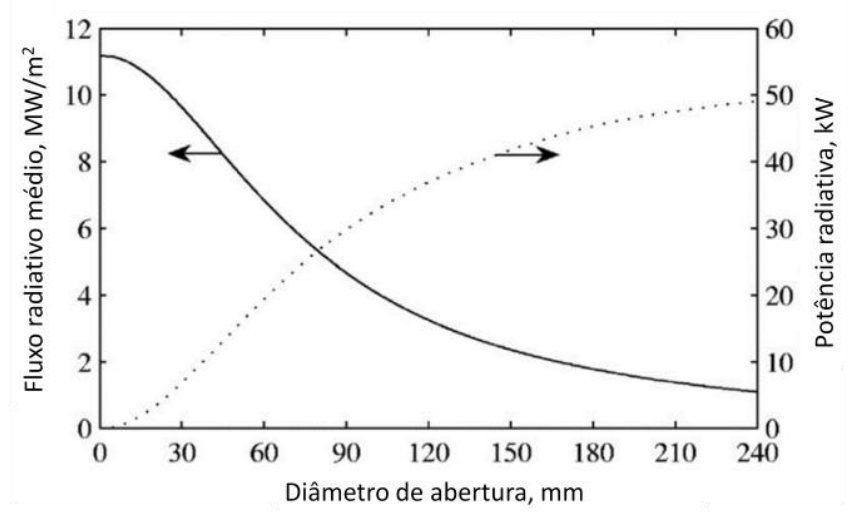

Figura 3.4 - Potências irradiantes médias e totais no plano do receptor-adaptado de Petrash et al (2007)

Como o conhecimento sobre o funcionamento dos simuladores solares de alto fluxo é pouco difundido e os resultados são majoritariamente empíricos, os parâmetros do aparato projetado foram baseados em desempenhos apresentados por modelos existentes no mundo, encontrados no levantamento de Alxneit e Dibowski (2011).

A área receptora considerada por Petrash et al (2007) foi um círculo de $60 \mathrm{~mm}$ de diâmetro. Como a potência estimada para o simulador desenvolvido é menor do que os modelos apresentados por Alxneit e Dibowski (2011), não é recomendado manter a mesma área receptora, pois a densidade de energia seria também menor. É preferível reproduzir uma alta concentração de energia em uma área menor, pois este fator é que garante a obtenção de altas temperaturas, essenciais para os experimentos. Assim, são previstos receptores também de menores dimensões e, por isso, o diâmetro do círculo-alvo receptor foi estabelecido em $25 \mathrm{~mm}$. Utilizando como exemplo os trabalhos desta bibliografia, os parâmetros esperados para o novo simulador são apresentados na Tabela 3.1: 
Tabela 3.1 - Características estimadas para o novo simulador solar

\begin{tabular}{|c|c|}
\hline Potência elétrica consumida (kW) & 8 \\
\hline № de lâmpadas & 2 \\
\hline Diâmetro focal receptor (mm) & 25 \\
\hline Potência térmica fornecida (kW) & 1 \\
\hline Concentração de radiação ("sóis") & 800 \\
\hline
\end{tabular}

\subsection{Configuração Final}

Uma vez estudados os aspectos construtivos e definidas as estimativas de saída do simulador solar, foi possível concluir o projeto e iniciar a etapa de busca de fornecedores e compra dos equipamentos e materiais que integram o aparato. Este projeto priorizou a facilidade de construção e operação do simulador solar proposto, buscando uma configuração inovadora que se utilizasse de equipamentos padronizados e comercializados em larga escala, o que ainda reduz o prazo e investimento para sua montagem.

Nesta etapa, algumas dificuldades foram encontradas, algumas delas capazes de alterar a configuração final do aparato. Primeiramente, constatou-se que o acionamento das lâmpadas de xenônio não representava uma etapa banal do projeto. O reator necessário para esta finalidade é bastante complexo devido à alta potência da lâmpada, o que demanda alta corrente e um controle confiável da tensão próximo ao valor nominal, a fim de garantir a segurança da operação (bulbo pressurizado). Assim, concluiu-se que seria impossível fabricar tal acionador no próprio laboratório, e partiu-se para a busca de fornecedores externos deste tipo de reator, que inclui ignitor e fonte de alimentação da lâmpada, ao redor do mundo.

Apenas dois fornecedores internacionais deste tipo de reator foram encontrados: na Itália e nos EUA. Porém, a compra deste equipamento não se mostrou a melhor 
alternativa ainda, uma vez que o custo de aquisição é muito elevado, em torno de US\$ 3.000,00/lâmpada. Assim, a alternativa encontrada foi a busca pelo mercado consumidor nacional deste tipo de lâmpada especial, a fim de se obter mais informações sobre diferentes sistemas de acionamento usados e, possivelmente, buscar peças descartadas por esses mercados e reutilizá-las, reduzindo o custo final. Dois mercados foram identificados como consumidores de lâmpadas de xenônio para sua aplicação principal: projetores de cinema e Sky Search Lights. Optou-se pelo último devido a sua relação custo $X$ benefício mais favorável para este fim.

Sky Search Lights são canhões de iluminação do céu de fácil ajuste direcional que se utilizam de lâmpadas de xenônio de alta potência para obter o alcance necessário. Eles possuem o sistema completo de acionamento deste tipo de lâmpada, com ignitor e fonte de alimentação, alguns modelos são dimerizáveis, apresentam operação e conexão à rede triviais, satisfazem requisitos de segurança do operador (lâmpada encapsulada) e ainda possuem o sistema de ventilação forçada embutido. A saída deste equipamento são raios paralelos, devido ao uso de um refletor parabólico interno.

Na Figura 3.5, um exemplo deste tipo de equipamento da marca HOLLE que se utiliza de uma lâmpada de xenônio de 4.000W. Este modelo é encontrado no mercado por aproximadamente $\mathrm{R} \$ 7.000,00$ (ano 2015): 


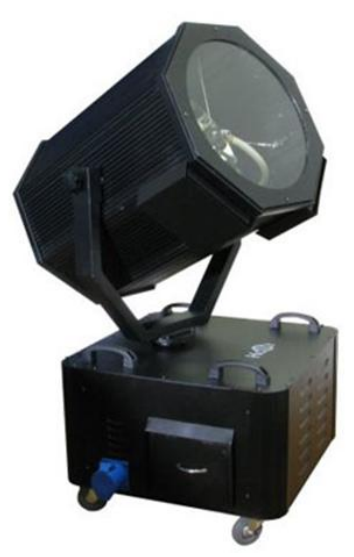

Figura 3.5 - Sky Search Lights de 4.000W de potência da marca HOLLE

A fim de evitar a substituição dos refletores parabólicos embutidos nos Sky Search Lights, a alternativa proposta foi a alteração da configuração inicial, composta por diversas associações refletor elipsoidal + lâmpada, por uma nova configuração com dupla reflexão, utilizando apenas um único refletor parabólico secundário para a concentração dos raios oriundos de todas as lâmpadas. Dessa forma, além de driblar a dificuldade construtiva da geometria elipsoidal, é possível fabricar tal refletor a partir de equipamentos existentes no mercado, como antenas parabólicas, ou através de diferentes processos de conformação utilizando moldes disponíveis.

Finalmente, a configuração final proposta para o simulador solar a ser construído é apresentada abaixo. Esta foi a montagem escolhida uma vez que se mostrou a mais adequada do ponto de vista econômico, técnico e prático. 


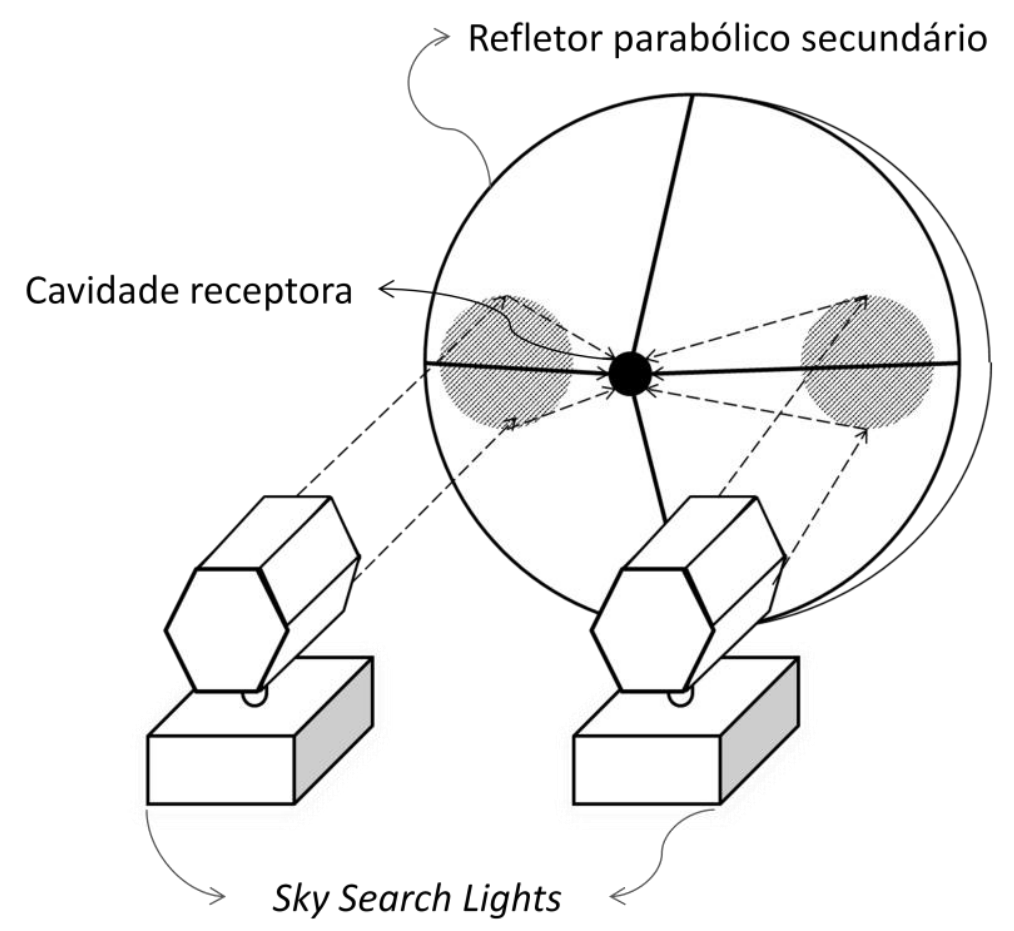

Figura 3.6 - Configuração final proposta para o simulador solar

Observa-se nesta representação esquemática que o refletor parabólico secundário apresenta área suficiente para comportar a região iluminada por diversos outros Sky Search Lights, o que faz com que o simulador solar construído possa ser facilmente ampliado para até 8 lâmpadas de xenônio, caso se julgue necessário para outros experimentos.

A Figura 3.7 apresenta o layout completo de instalação do aparato. É importante observar neste projeto CAD que o simulador solar apresenta-se isolado da área comum do laboratório por divisórias, a fim de garantir a segurança do operador e dos demais frequentadores, uma vez que a lâmpada de xenônio utilizada é composta por um bulbo pressurizado e existe um pequeno risco de explosão caso sua temperatura não seja rigorosamente controlada. Além do ambiente isolado e controlado, o uso de equipamentos de segurança para a manipulação do equipamento é imprescindível. 


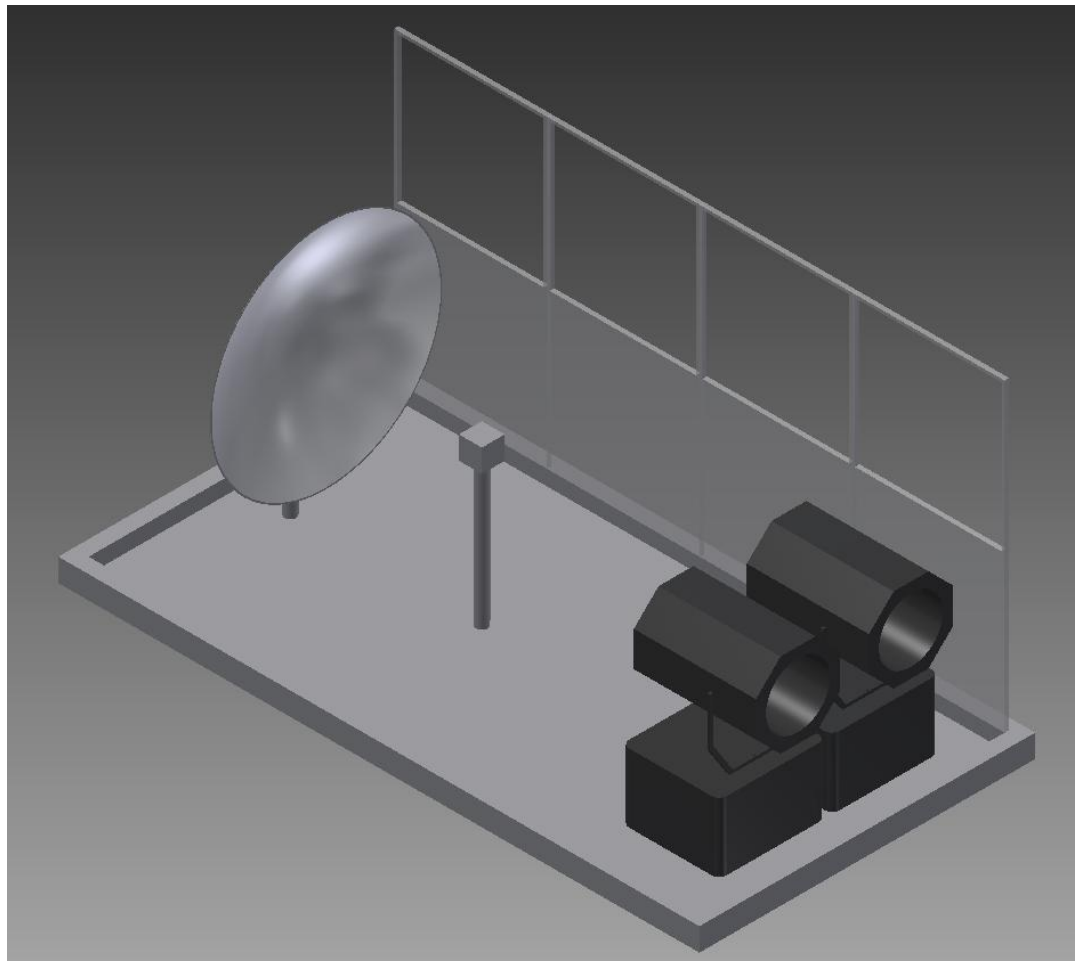

Figura 3.7- Layout da instalação completa do simulador solar 


\section{ARRANJO EXPERIMENTAL}

Este capítulo descreve o conjunto completo do simulador solar concentrador fabricado, assim como o aparato de testes construído a fim de avaliar a qualidade do projeto, a resistência dos componentes e o fator de concentração do equipamento. Logo após a visão geral do sistema, cada um dos seus principais componentes será detalhado separadamente.

\subsection{Descrição do Sistema - Visão Geral}

O esquema ilustrado na figura abaixo representa a visão geral do sistema e seus principais componentes:

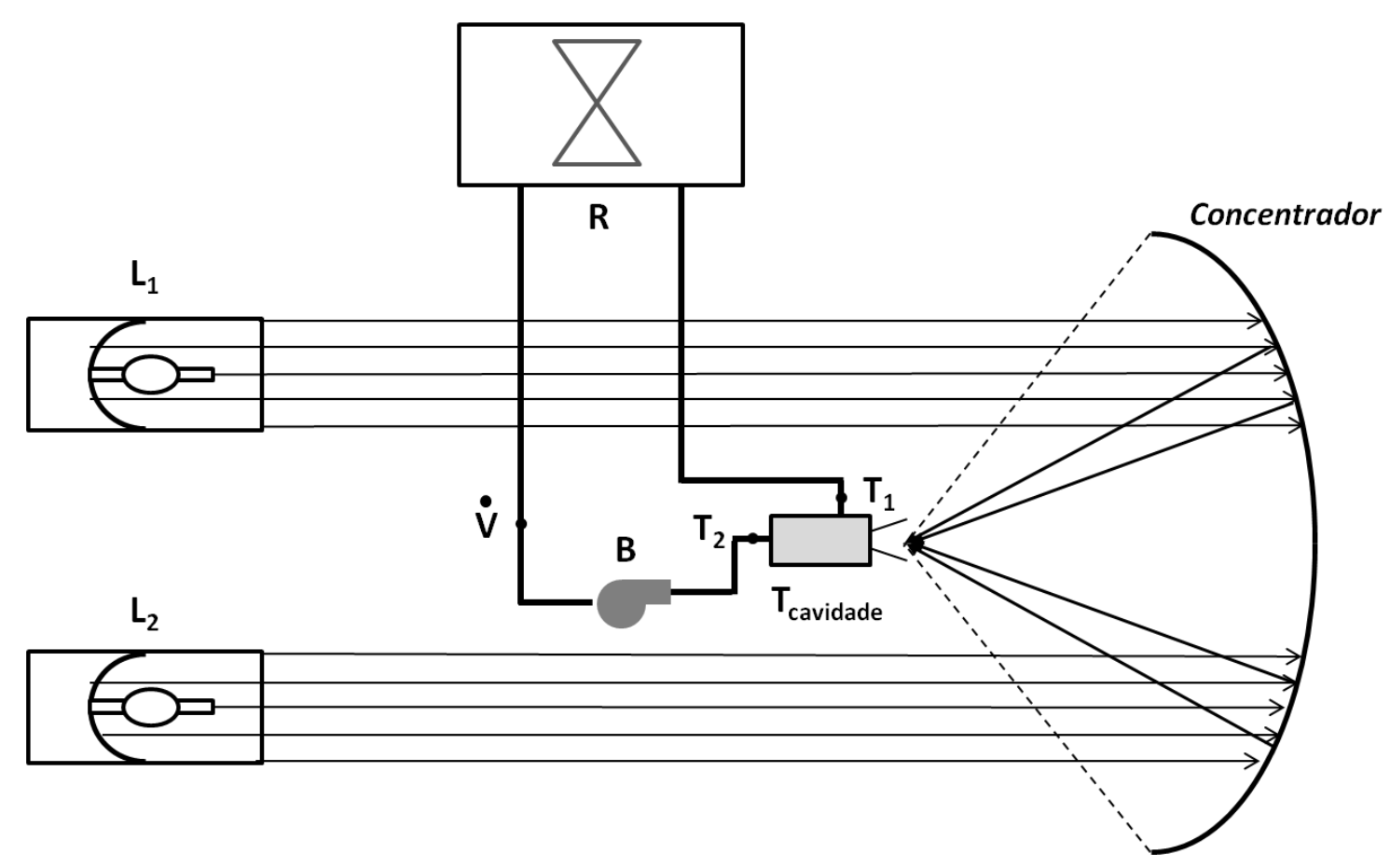

Figura 4.1 - Visão geral do sistema e seus principais componentes

Onde:

$L_{1}$ é a fonte luminosa 1 
$L_{2}$ é a fonte luminosa 2

Concentradoré o refletor parabólico secundário

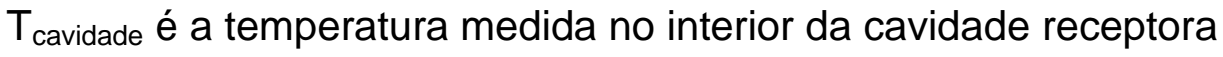

$\mathrm{T}_{1}$ é a temperatura medida na entrada da cavidade receptora

$\mathrm{T}_{2}$ é a temperatura medida na saída da cavidade receptora

$\dot{V}$ é a vazão volumétrica medida no circuito de resfriamento de água

B é a motobomba do circuito de resfriamento de água

$\mathrm{R}$ é o trocador de calor do circuito de resfriamento de água

\subsection{Refletor Parabólico Secundário}

$\mathrm{Na}$ configuração de simulador solar concentrador com dupla reflexão, o refletor parabólico secundário é o elemento usado para concentração dos feixes de raios paralelos provenientes das lâmpadas.

No projeto em questão, optou-se pela fabricação própria do refletor parabólico através da técnica de conformação com fibra de vidro utilizando um molde de mesma geometria (detalhes apresentados no Anexo A.1).

Uma vez assegurada a geometria parabólica, foi preciso ainda revestir a superfície interna da peça, a fim de garantir a sua qualidade de elevada refletância direcional, assemelhando-se a um espelho. Para isso, optou-se pelo uso de uma película autoadesiva refletora, uma vez que a amostra apresentou uma média de refletância satisfatória em comparação aos demais materiais testados, além de ser um 
revestimento de fácil aplicação. As principais dimensões do molde utilizado para conformação da peça e o resultado final do revestimento do refletor parabólico são apresentados na Figura 4.2:
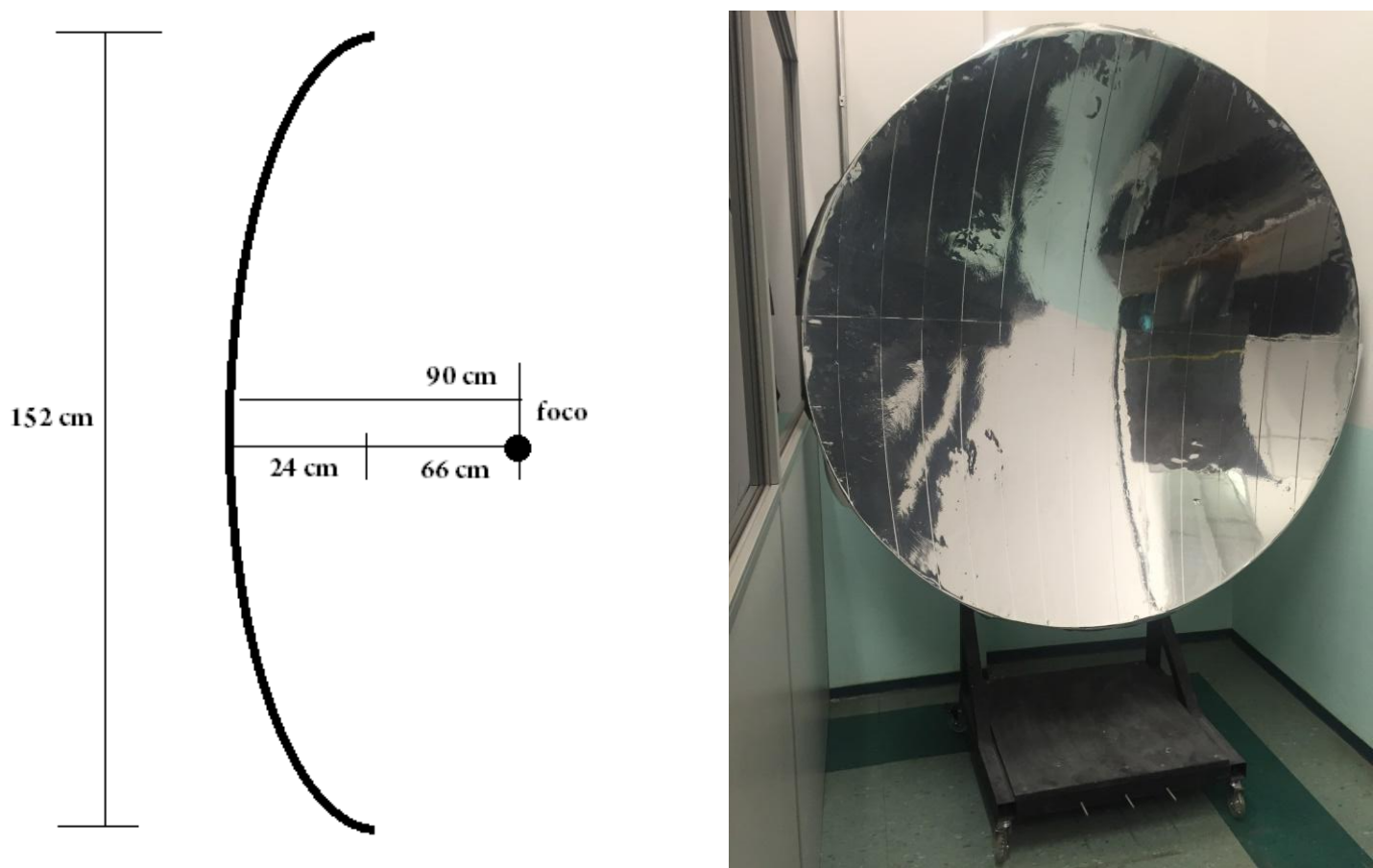

Figura 4.2 - Principais dimensões do refletor parabólico e resultado após revestido com película autoadesiva refletora

\subsection{Fonte Luminosa}

Já é sabido que a alternativa escolhida para a fonte luminosa do simulador solar foi o uso de Sky Search Lights, canhões de iluminação do céu que se utilizam de lâmpadas de xenônio de alta potência para obter o alcance necessário, devido a suas inúmeras vantagens operacionais. Dessa forma, partiu-se para a etapa de cotação e compra desse equipamento.

O modelo escolhido foi o mesmo dado como exemplo na seção anterior: Sky Search Light da marca HOLLE que utiliza uma lâmpada de xenônio de 4.000W. Além de apresentar uma potência adequada para a aplicação em questão, este modelo 
também demonstrou uma boa relação custo $X$ benefício. Abaixo, a foto do equipamento entregue no laboratório SISEA:

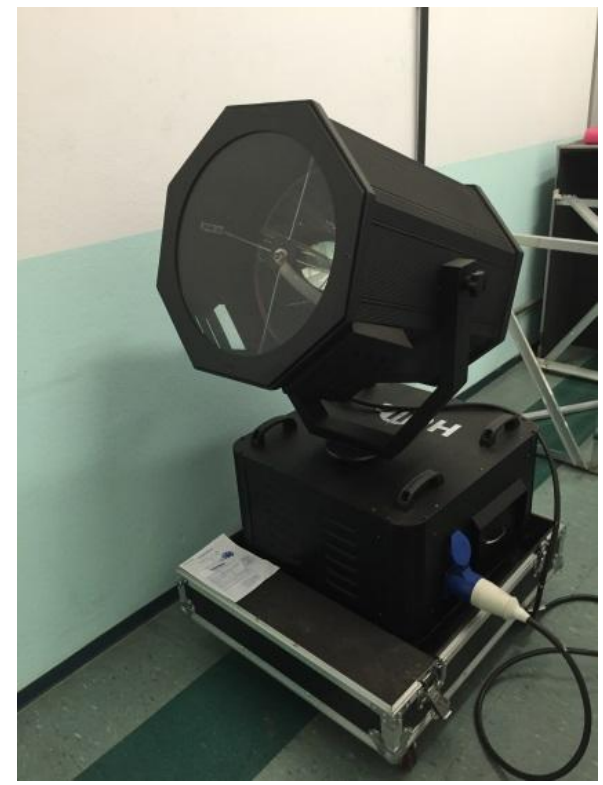

Figura 4.3 - Sky Search Light adquirido como fonte luminosa do simulador solar

\subsection{Cavidade Receptora}

A fim de avaliar a potência térmica fornecida pelo simulador solar no foco do concentrador, optou-se pela fabricação de uma cavidade receptora simples e de um circuito de água instrumentado com sensores de vazão e temperatura ao longo do percurso.

Um suporte sobre rodas foi totalmente fabricado no laboratório para fixação da cavidade receptora, não apenas a utilizada para os testes iniciais do simulador solar, mas também as específicas para cada projeto desenvolvido no laboratório, garantido sua movimentação com 3 graus de liberdade para correto posicionamento no foco luminoso: 

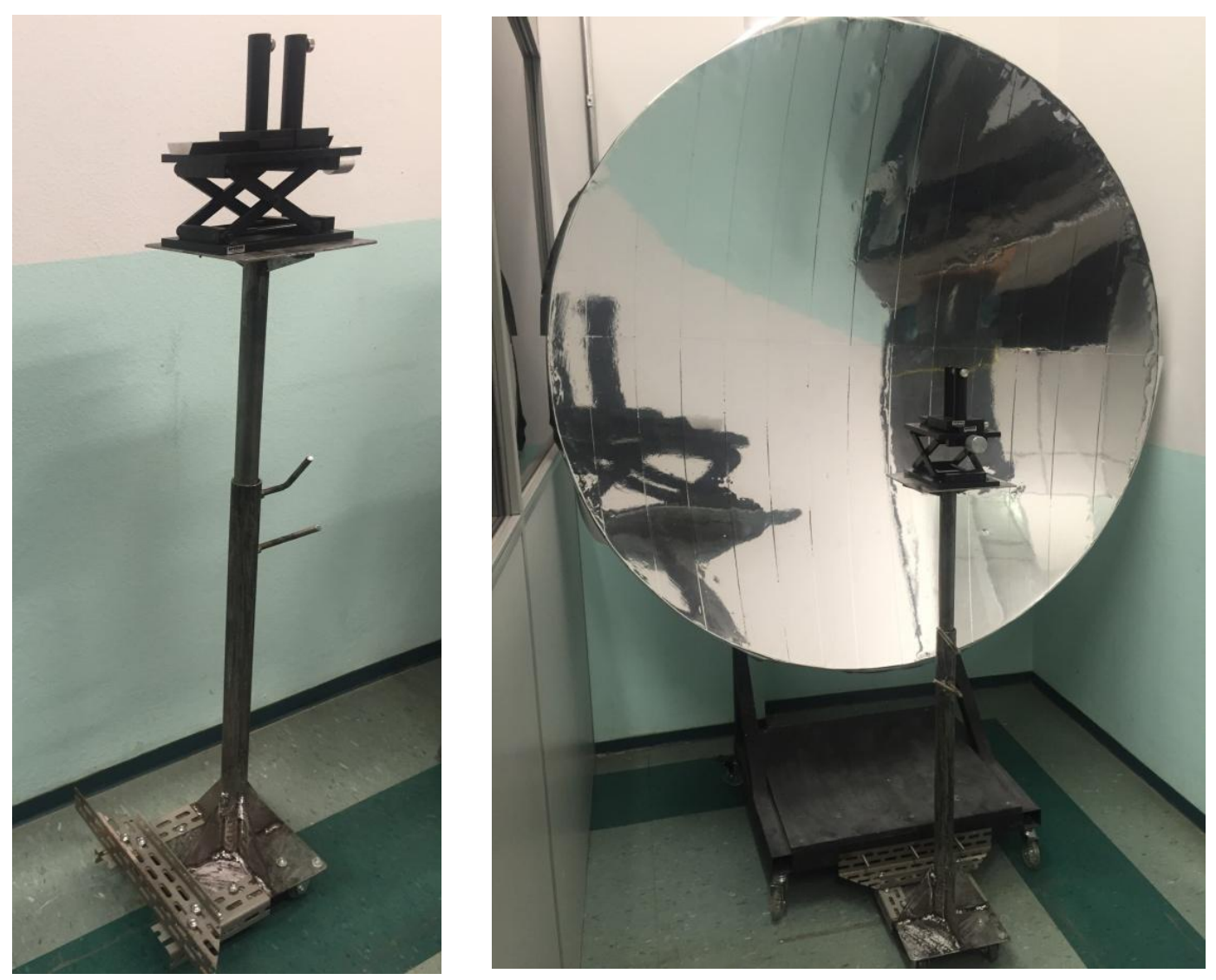

Figura 4.4 - Suporte móvel para fixação de cavidades receptoras no foco do concentrador com três graus de liberdade e aparato final montado

A cavidade é uma forma geométrica que visa otimizar a absorção de radiação. Para isso, uma pequena abertura permite a entrada de radiação térmica para dentro de um espaço confinado adiabático, o que faz com que a radiação incidente seja absorvida e refletiva diversas vezes no interior da cavidade até que seja totalmente absorvida. Nesse processo, uma temperatura (adiabática) de equilíbrio é estabelecida.

Sabe-se que a absortividade efetiva da cavidade tende para unidade, independentemente do material construtivo, desde que a razão entre a área de abertura e a área interna total seja muito pequena. Isto significa que a cavidade se comporta como um corpo negro. 
Para o projeto em questão, optou-se pela fabricação de uma cavidade receptora cilíndrica em aço, com 113 mm de diâmetro e 200 mm de comprimento (espessura das paredes de $3,75 \mathrm{~mm}$ ), totalmente revestida por uma espessa camada de manta térmica a fim de garantir sua função adiabática. Em seu interior, através de uma serpentina fabricada com tubo de cobre de $9,5 \mathrm{~mm}$ de diâmetro e $1 \mathrm{~mm}$ de espessura, circula o fluido de teste, conforme Figura 4.5:

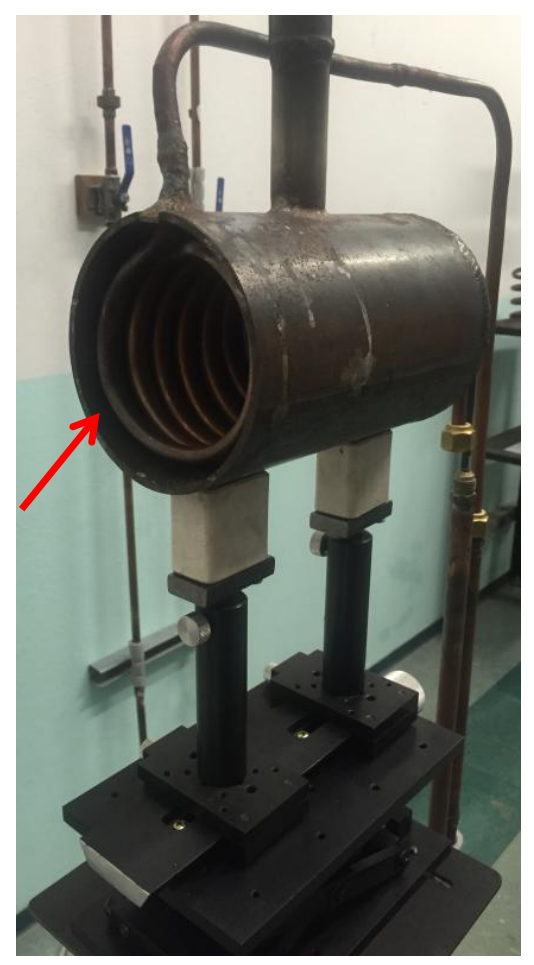

Figura 4.5 - Cavidade receptora, com destaque para sua serpentina interna de cobre

A entrada da cavidade, com $40 \mathrm{~mm}$ de diâmetro, foi equipada com duas janelas de quartzo fundido separadas por $2 \mathrm{~mm}$ e um cone metálico foi incorporado à frente da abertura para aumentar a taxa de concentração e reduzir as perdas por reirradiação, ou seja, garantir a entrada de maior parte da energia radiativa na cavidade. $O$ projeto final da cavidade receptora é apresentado na figura abaixo: 

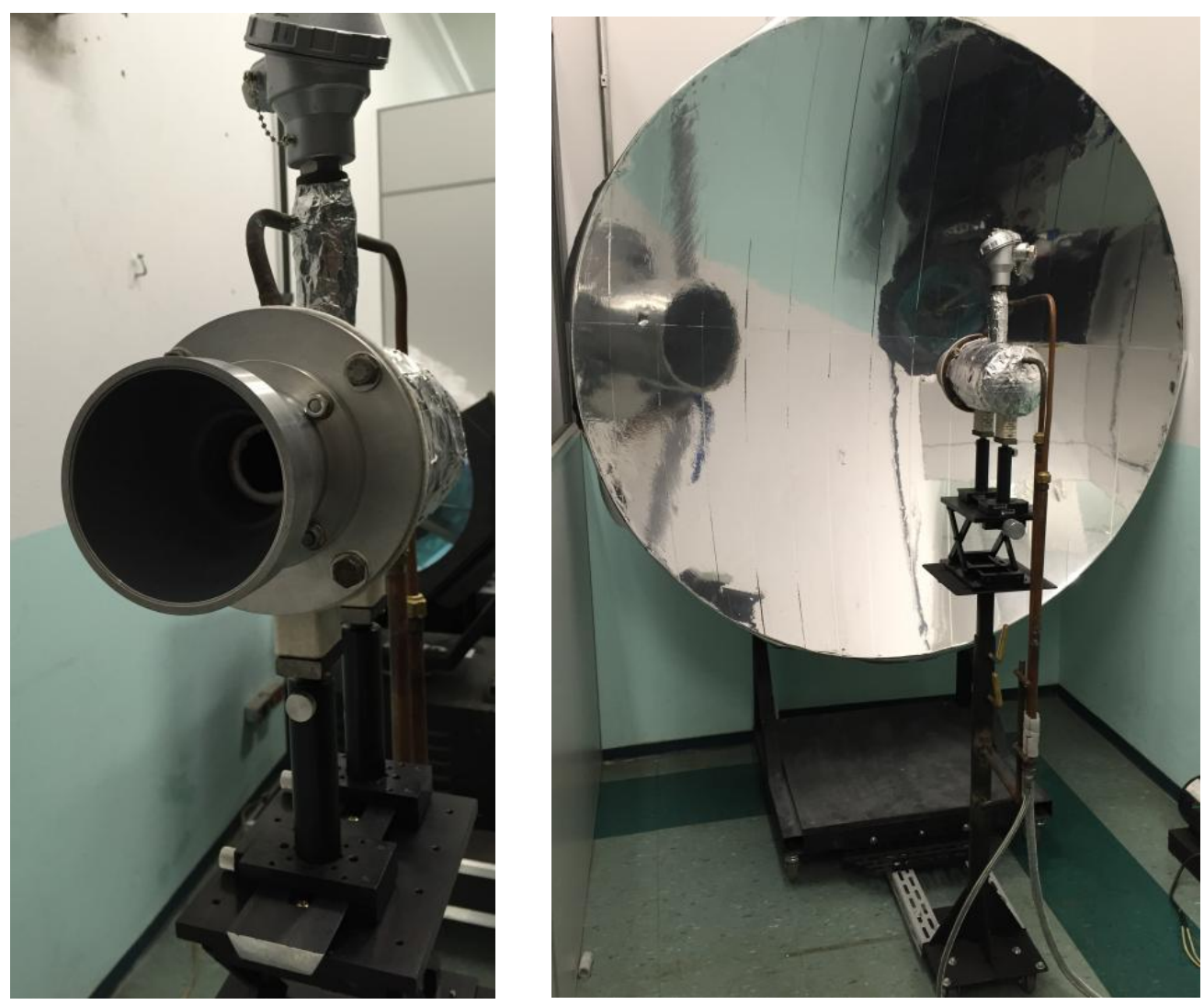

Figura 4.6 - Montagem final da cavidade receptora

\subsection{Circuito de Água}

O circuito fechado de água projetado percorre a cavidade receptora, no interior da serpentina de cobre inserida na cavidade (Figura 4.5), e um trocador de calor externo, com sensores de vazão e temperatura estrategicamente posicionados ao longo deste percurso. Com os dados coletados por esses sensores, é possível avaliar a quantidade de energia que adentra a cavidade receptora por unidade de tempo, ou seja, a potência térmica fornecida pelo simulador solar no foco do concentrador, através da $1^{\underline{a}}$ Lei da Termodinâmica.

O circuito foi inteiramente fabricado com tubos de cobre de $15 \mathrm{~mm}$ de diâmetro e $0,75 \mathrm{~mm}$ de espessura, e instrumentado com um sensor de vazão volumétrica do tipo rotâmetro e termopares do tipo $J$ para medição da temperatura do fluido na 
entrada e na saída da cavidade receptora. Um radiador automotivo com aletas de alumínio foi usado como trocador de calor e uma válvula de expansão foi posicionada no ponto mais alto do circuito, como destacado na Figura 4.7:
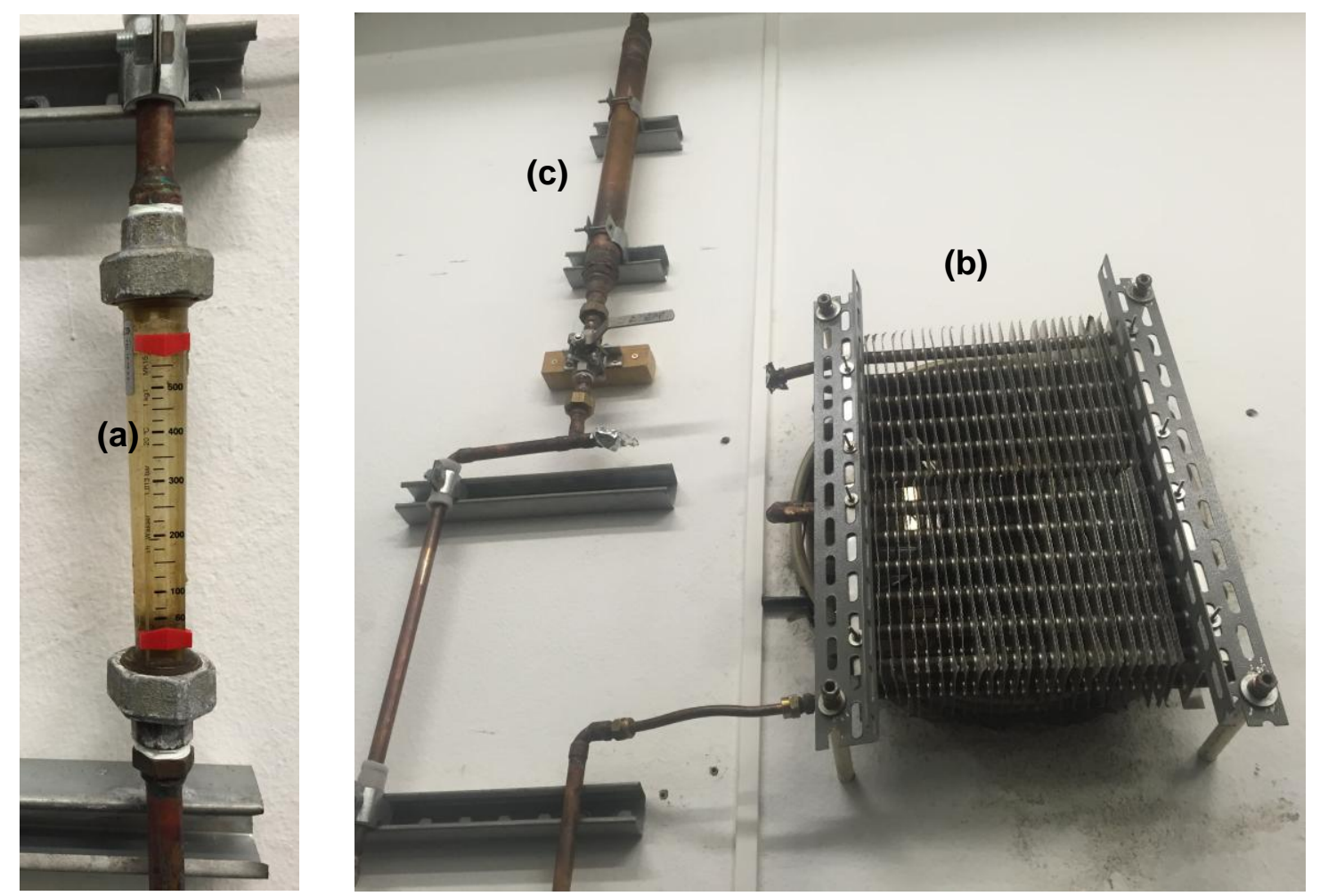

Figura 4.7- Destaque para: (a) sensor de vazão volumétrica - rotâmetro; (b) trocador de calor radiador automotivo e (c) válvula de expansão do circuito de água

Para forçar a circulação do fluido através dos dutos, uma motobomba de 1/4 CV da marca Schneider ${ }^{\circledR}$ foi instalada no circuito, assim como um medidor de pressão acoplado e válvulas de segurança para garantir as condições ideias de operação: 


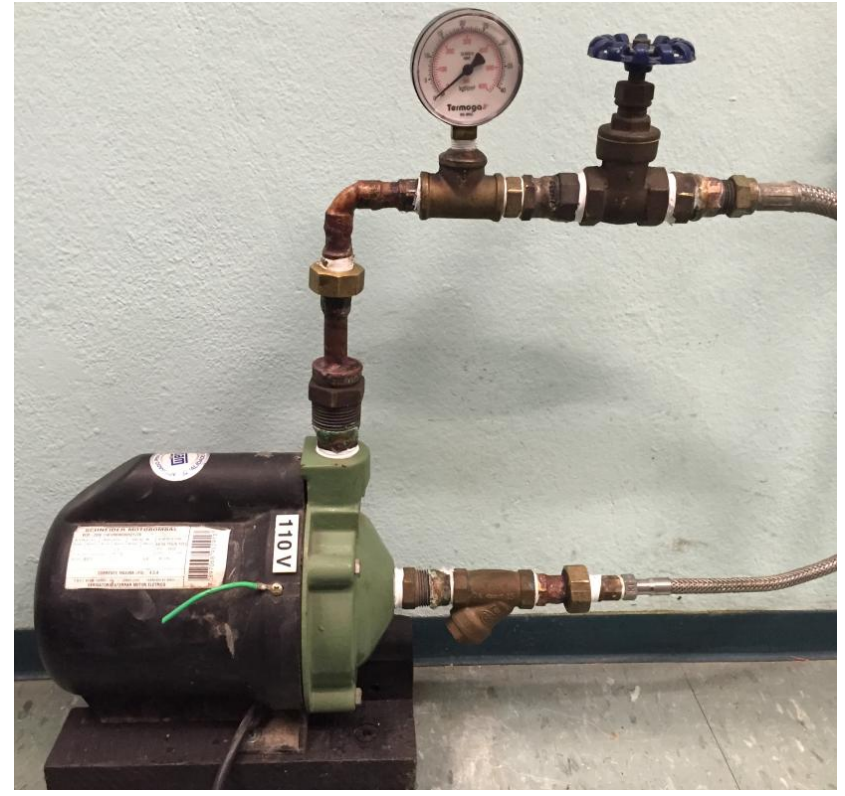

Figura 4.8 - Destaque para a motobomba Schneider ${ }^{\circledast}$ de $1 / 4$ CV O resultado final é apresentado na Figura 4.9:

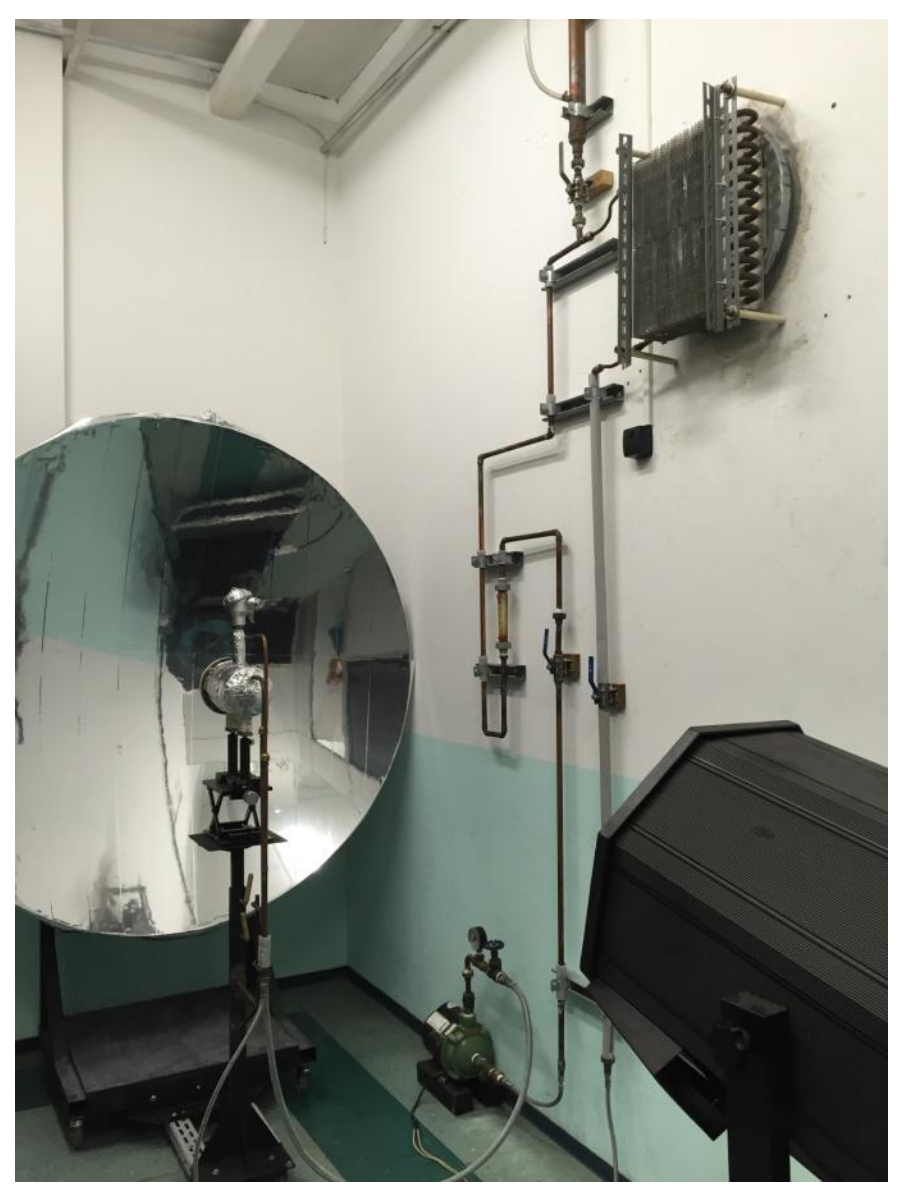

Figura 4.9 - Arranjo experimental completo 


\section{PROCEDIMENTO DE TESTES}

\subsection{Avaliação do Perfil Espectral da Lâmpada}

No estudo espectral da radiação, a grandeza a ser medida é a irradiância espectral $\left(\mathrm{W} / \mathrm{m}^{2} / \mathrm{nm}\right)$ em cada faixa de comprimento de onda de uma fonte de radiação. $\mathrm{O}$ instrumento geralmente utilizado para este fim em aparatos que simulam a radiação solar é o espectrômetro. O resultado obtido com ele é um gráfico como o apresentado na Figura 5.1, que representa a curva de emissão de radiação de uma lâmpada em comparação com a distribuição solar:

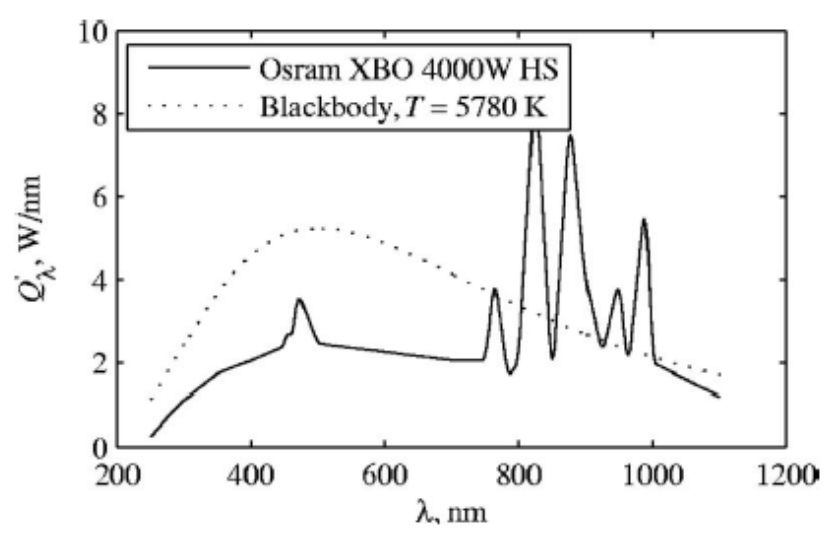

Figura 5.1 - Distribuição espectral da potência emissiva radiativa de uma lâmpada de xenônio e de um corpo negro (Sol) a $5780 \mathrm{~K}$ (Petrash et al, 2007)

Espectrômetros são instrumentos utilizados para medir as propriedades espectrais de uma fonte de radiação. Em resumo, a função básica do espectrômetro é receber a luz, dividi-la em seus componentes espectrais, digitalizar o sinal em função do comprimento de onda, interpretar estas informações e apresentá-las na tela do computador. Eles têm como propriedade básica operar sobre uma ampla faixa de frequência que vai do ultravioleta ao infravermelho.

A Figura 5.2 apresenta uma disposição dos componentes internos de um espectrômetro padrão e uma representação esquemática, utilizada para fins didáticos, que simplifica as etapas de operação do aparato. A primeira delas 
consiste em direcionar a luz que flui pelo cabo de fibra ótica para o interior do espectrômetro através de uma pequena abertura. A luz divergente que entra é retificada pelo colimador, um espelho côncavo, que direciona o fluxo para a grade de difração. A rede de difração então dispersa os componentes espectrais da luz em ângulos ligeiramente diferentes. Observa-se que a luz chega homogênea a ela e sai dividida em faixas de comprimentos de onda que vão do UV, passam pelos espectros visíveis, e chegam ao IV. Os feixes são divergidos por um segundo espelho côncavo para que o espectro fique mais espalhado, aumentando a resolução. Após serem retificados novamente por uma lente, os feixes de luz atingem os detectores.

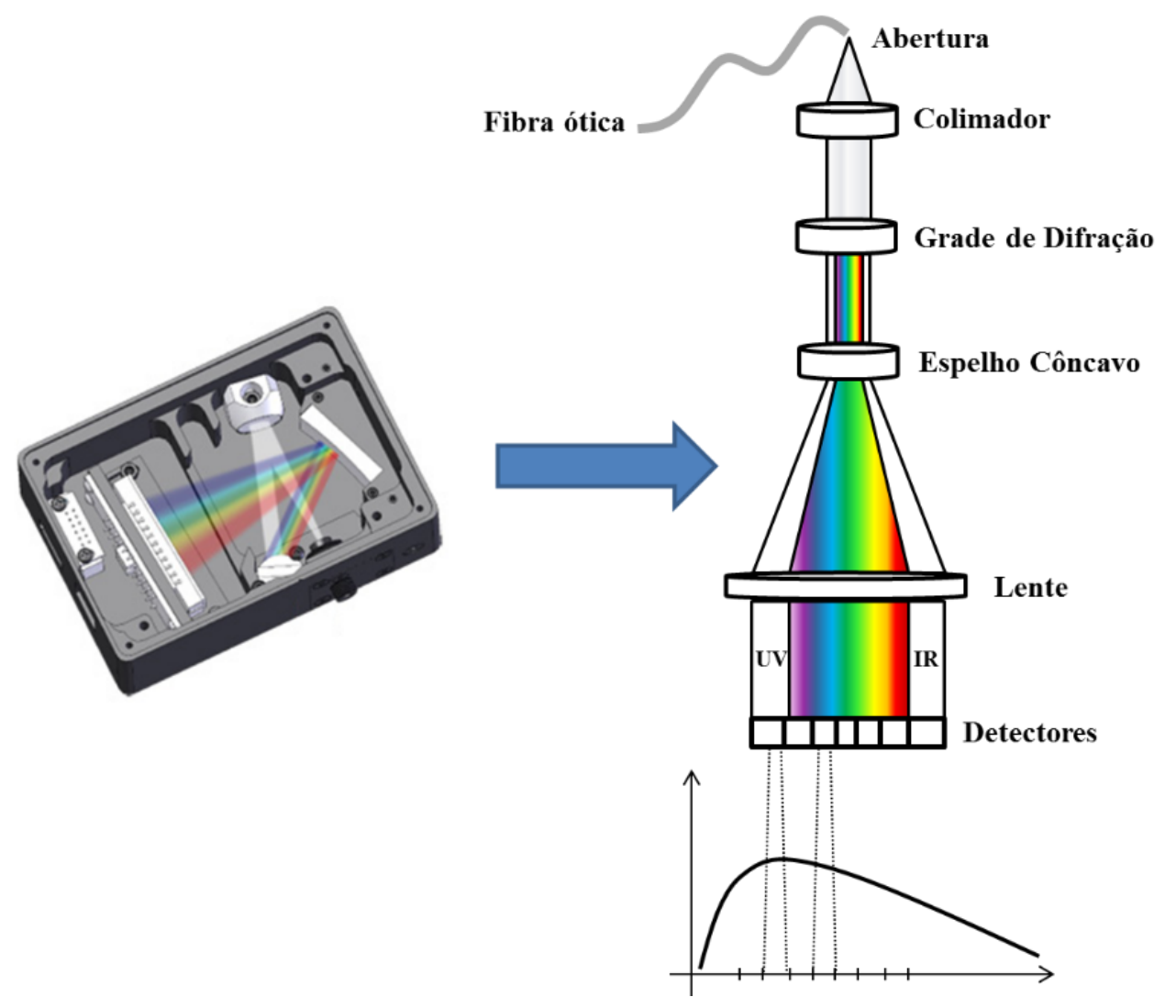

Figura 5.2 - Componentes internos de um espectrômetro e representação esquemática de seu funcionamento

Quando a luz reflete no detector, os fótons excitam os elétrons, que são digitalizados e transmitidos ao computador. Um software interpola o sinal baseado no número do 
pixel para criar uma calibração que permita que os dados sejam plotados como função do comprimento de onda pela faixa espectral dada.

Após um estudo mais aprofundado e uma consulta mais detalhada a outros projetos de simuladores solares, verificou-se que a potência total irradiada é mais importante do que a fidelidade ao perfil emissivo solar para aplicações térmicas. Desta forma, descartou-se o uso de filtros, pois isso significaria a perda da potência inerente aos comprimentos de onda filtrados, e o uso do espectrômetro será exclusivamente para validar o perfil emissivo das lâmpadas adquiridas com as apresentadas pelos seus fabricantes.

Uma pesquisa minuciosa sobre tipos de espectrômetros para aplicações científicas foi feita e optou-se pela importação do modelo USB2000+XR1 da Ocean Optics, juntamente com os acessórios que são necessários para a realização do experimento: software integrado de controle e operação, corretor cossenoide, extensão da fibra ótica de entrada, lente colimadora e fonte de Tungstênio Halogênio para calibração do equipamento. O kit chegou ao país em março de 2015 e está representado na Figura 5.3:

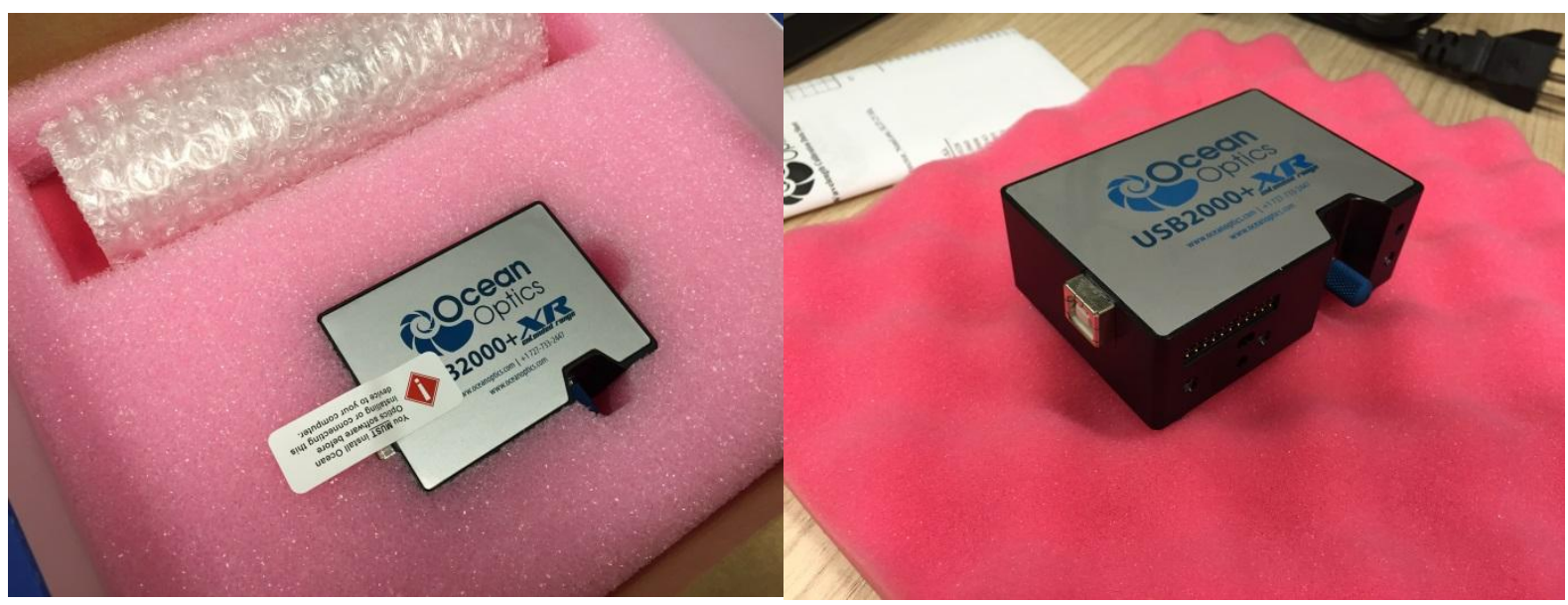

Figura 5.3 - Espectrômetro USB2000+XR1 da Ocean Optics adquirido para testes no simulador solar 
Para os experimentos com o espectrômetro adquirido, uma pequena bancada de testes óticos foi confeccionada, constituída por um trilho de metal com a função de guia dos acessórios, e um aparato receptor plano onde se posiciona a superfície de teste ou o espelho:

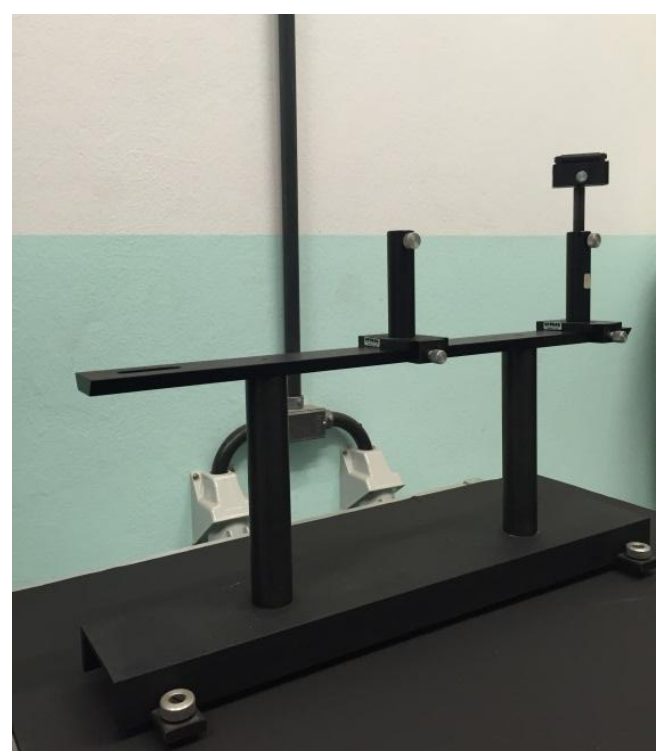

Figura 5.4 - Bancada de testes óticos

\subsection{Avaliação do Fluxo de Calor no Foco do Concentrador}

Como já mencionado anteriormente, a diferença entre a potência elétrica consumida pelas lâmpadas e a potência térmica irradiante no receptor se dá devido à eficiência total do aparato. Fatores de correção teóricos são aplicados para a estimativa da potência térmica devido à eficiência elétrica das lâmpadas, à refletividade dos refletores e, principalmente, à eficiência de concentração.

A fim de avaliar na prática a estimativa estabelecida para o projeto do simulador solar em questão, optou-se pela fabricação de um circuito de água para aferição da quantidade de calor percebida no foco do concentrador através da tomada de dados de vazão e temperatura ao longo do percurso (análise da 1aㅡ Lei da Termodinâmica). O circuito de água projetado percorre a cavidade receptora, onde o fluido é 
aquecido, e um trocador de calor externo, onde o fluido é resfriado, com sensores de vazão e temperatura estrategicamente posicionados ao longo deste percurso.

Com os dados coletados por esses sensores, é possível avaliar a quantidade de energia que adentra a cavidade receptora por unidade de tempo, ou seja, a potência térmica fornecida pelo simulador solar no foco do concentrador, através da fórmula:

$$
\begin{gathered}
\dot{Q}=\dot{m} \times c \times \Delta T \\
\dot{Q}=(\rho . \dot{V}) \times c \times \Delta T
\end{gathered}
$$

Onde:

$\dot{Q}$ é o fluxo de calor a ser determinado [W]

$\rho$ é a densidade do fluido $\left[\mathrm{kg} / \mathrm{m}^{3}\right]$

$\dot{V}$ é a vazão volumétrica do fluido $\left[\mathrm{m}^{3} / \mathrm{s}\right.$ ]

$c$ é o calor específico do fluido [J/(kg.K)]

$\Delta T$ é a variação de temperatura do fluido $[\mathrm{K}]$

Na prática, as principais fontes de perda do simulador solar são ilustradas na Figura 5.5. A perda no equipamento está relacionada à eficiência elétrica dos Sky Search Lights fornecida pelo próprio fabricante $(4,4 \%$ a $22 \%$ dependendo das condições de operação): $100 \%-20 \% \approx 80 \%$. Já a perda no refletor parabólico, que representa a parcela de energia luminosa absorvida pelo substrato do refletor e não refletida por sua superfície, é definida com base na refletância da película autoadesiva refletora 
que reveste a peça (resultado dos testes apresentado no Anexo A.1): 1 - 0,85 =0,15 $=15 \%$.

Potência elétrica consumida

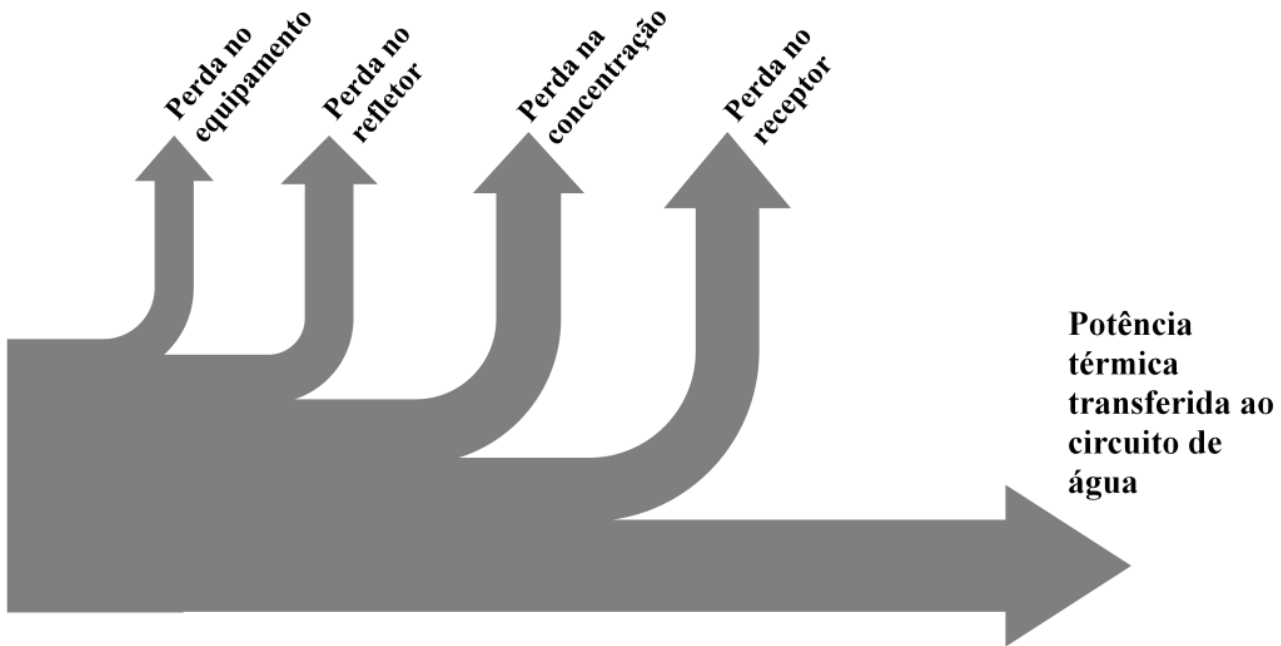

Figura 5.5 - Esquema ilustrativo das principais perdas ao longo do percurso luminoso

A perda no receptor consiste na parcela de energia radiativa que adentra a cavidade, porém não é absorvida pelo circuito de água devido a perdas por condução, convecção e reirradiação. Esta parcela pode ser estimada de maneira teórica, baseada no balanço térmico por analogia elétrica da cavidade receptora (detalhes apresentados no Anexo A.3): $7 \%$.

Dessa forma, uma vez que todas as demais perdas foram definidas, é possível estimar por diferença a perda na concentração, objeto de estudo. A perda na concentração refere-se à parcela de raios luminosos que não atinge o foco do concentrador por irregularidades na superfície refletora, ou por desvios na direção de incidência da luz e na geometria parabólica. Assim, o valor desta perda está diretamente relacionado à qualidade construtiva do simulador solar concentrador e por isso será avaliado. 
$\mathrm{Na}$ Figura 5.6 observa-se o esquema simplificado do aparato de testes (vista superior), com destaque para o percurso desenvolvido pelos feixes de luz desde a fonte luminosa até atingirem a cavidade receptora. É possível constatar três variações na quantidade de energia ao longo do percurso:

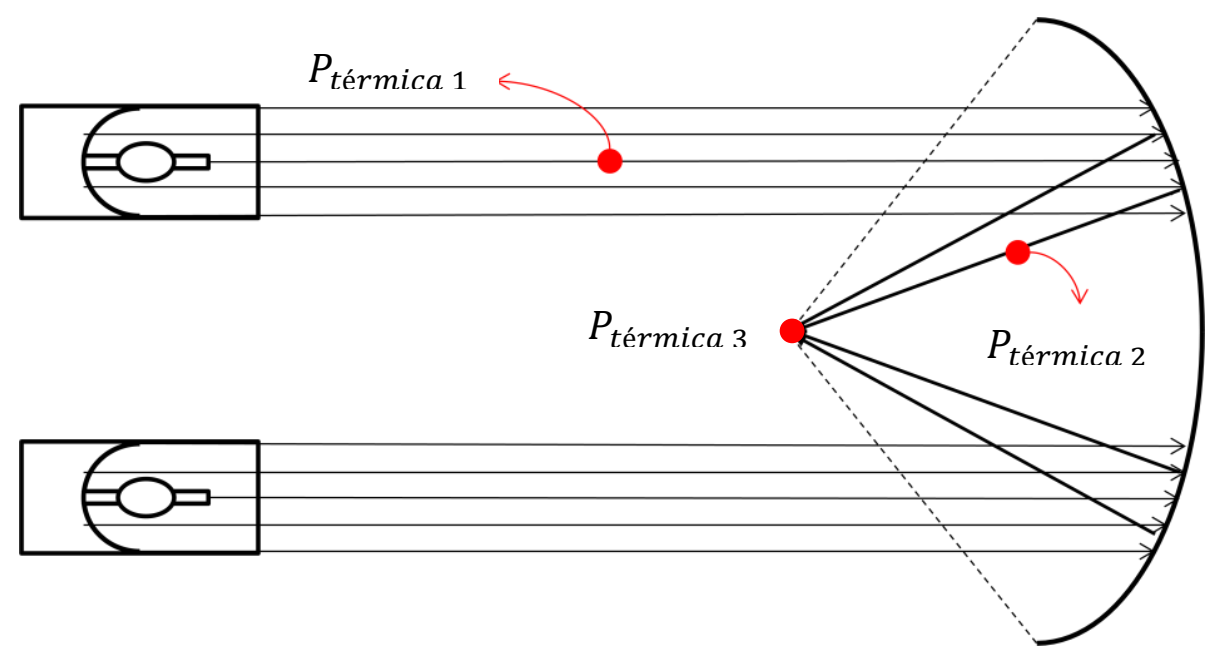

Figura 5.6 - Representação esquemática do simulador solar e da variação da quantidade de energia ao longo do percurso luminoso

Potência térmica 1:

$$
P_{\text {térmica } 1}=\dot{\eta}_{\text {equipamento }} \times P_{\text {elétrica }}
$$

Onde:

$\dot{\eta}_{\text {equipamento }}$ é a eficiência elétrica dos Sky Search Lights $=\mathbf{0 , 2 0}$

$P_{\text {elétrica }}$ é potência elétrica dos Sky Search Lights [W]

Potência térmica 2:

$$
P_{\text {térmica 2 }}=P_{\text {térmica } 1} \times \dot{\eta}_{\text {refletor }}
$$

Onde: 
$\dot{\eta}_{\text {refletor }}$ é a eficiência de reflexão da película autoadesiva refletora que reveste o refletor parabólico $=\mathbf{0 , 8 5}$

Potência térmica 3:

$$
P_{\text {térmica } 3}=P_{\text {térmica } 2} \times \dot{\eta}_{\text {concentração }}
$$

Onde:

$\dot{\eta}_{\text {concentração }}$ é a eficiência de concentração do concentrador parabólico

$$
P_{\text {térmica } 3} \times \dot{\eta}_{\text {receptor }}=\dot{Q} \rightarrow P_{\text {térmica } 3}=\frac{\dot{Q}}{\dot{\eta}_{\text {receptor }}}
$$

Onde:

$\dot{Q}$ é o fluxo de calor no circuito de água [W]

$\dot{\eta}_{\text {receptor }}$ é a eficiência de absorção da cavidade receptora $=\mathbf{0 , 9 3}$

Assim:

$$
\begin{aligned}
& P_{\text {térmica } 3}=\frac{(\rho . \dot{V}) \times c \times \Delta T}{\dot{\eta}_{\text {receptor }}} \rightarrow P_{\text {térmica } 2} \times \dot{\eta}_{\text {concentração }}=\frac{(\rho . \dot{V}) \times c \times \Delta T}{\dot{\eta}_{\text {receptor }}} \\
& \dot{\eta}_{\text {concentração }}=\frac{(\rho . \dot{V}) \times c \times \Delta T}{\dot{\eta}_{\text {receptor }} \times P_{\text {térmica } 2}} \\
& \dot{\eta}_{\text {concentração }}=\frac{(\rho \dot{V}) \times c \times \Delta T}{\dot{\eta}_{\text {receptor }} \times P_{\text {térmica } 1} \times \dot{\eta}_{\text {refletor }}} \\
& \dot{\eta}_{\text {concentração }}=\frac{(\rho . \dot{V}) \times c \times \Delta T}{P_{\text {elétrica }} \times \dot{\eta}_{\text {equipamento }} \times \dot{\eta}_{\text {refletor }} \times \dot{\eta}_{\text {receptor }}}
\end{aligned}
$$




\section{RESULTADOS}

No teste para avaliar o perfil espectral da lâmpada de xenônio usada no simulador solar, como já mencionado, a grandeza medida é a irradiância espectral $\left(\mathrm{W} / \mathrm{m}^{2} / \mathrm{nm}\right)$ em cada faixa de comprimento de onda da fonte de luz. O instrumento utilizado para este fim foi o espectrômetro modelo USB2000+XR1 da Ocean Optics e seus acessórios, adquiridos durante o projeto.

O procedimento do teste é bem simples: com o software do equipamento - Ocean View - devidamente instalado, o espectrômetro é conectado ao computador e a função "irradiância relativa" selecionada para iniciar uma nova tomada de dados, ajustando-se o tempo de integração em 100 ms e o número de medições para se determinar o resultado médio em 5 repetições. Nesta modalidade, o equipamento é capaz de medir a qualidade da fonte de luz, ou seja, a distribuição relativa de intensidade emissiva ao longo da faixa de operação do espectrômetro (diferentes comprimentos de onda).

A radiação usada como referência neste teste foi a fonte luminosa de Tungstênio Halogênio, modelo HL-2000-LL da Ocean Optics, adquirida junto ao espectrômetro. Isto significa que a resposta do detector do equipamento estará ajustada segundo a curva de emissão espectral de um corpo negro a $2.400 \mathrm{~K}$, mesma temperatura de cor da radiação de referência.

A fonte é ligada e aguardam-se 10 minutos até que sua radiação se estabilize. Então, uma extremidade da fibra ótica é conectada ao espectrômetro, enquanto a outra, na qual o corretor cossenoide está fixado, é apontada diretamente para a saída da fonte de Tungstênio Halogênio; o espectro de referência é medido e registrado pelo software. É importante certificar-se de que o espectro não está 
saturado antes de registrar os dados; caso necessário, ajuste o tempo de integração.

Em seguida, a referência de radiação nula é registrada pelo software bloqueando-se a extremidade da fibra ótica com o corretor cossenoide para impedir a passagem de luz. Uma vez que a referência de zero e de radiação padrão estejam estipuladas, o espectrômetro já está apto a medir a irradiância relativa de qualquer fonte de luz.

O resultado obtido ao aproximar-se a extremidade da fibra ótica com o corretor cossenoide da radiação emitida pela lâmpada de xenônio de 4.000W do Sky Search Light é apresentado na Figura 6.1:

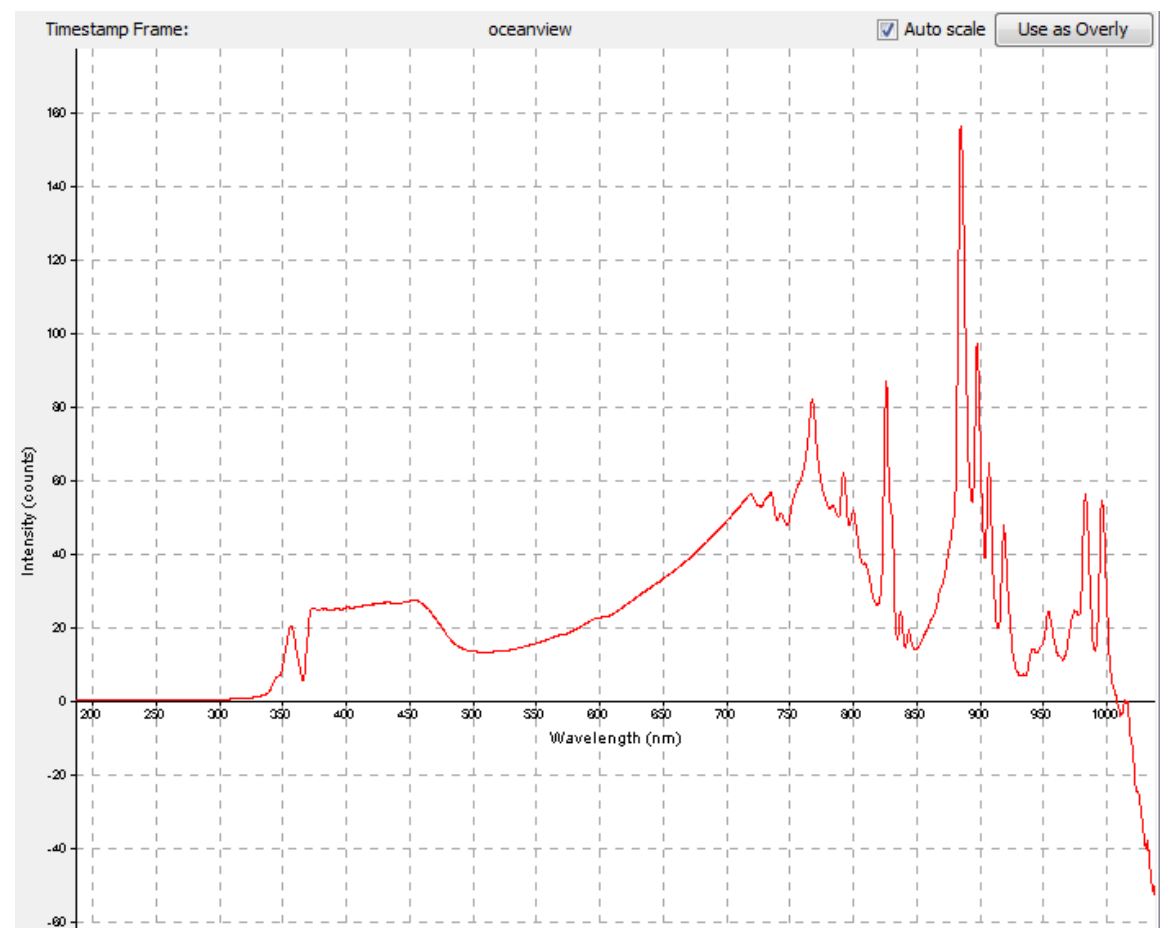

Figura 6.1 - Resultado do teste de irradiância relativa - distribuição de intensidade emissiva por comprimento de onda

Comparando-se a curva de distribuição relativa de intensidade emissiva obtida com a curva padrão de uma lâmpada de xenônio, apresentada na Figura 3.1, é possível constatar que o resultado é bem próximo do esperado uma vez que a curva 
experimental segue o mesmo padrão da curva de referência até o comprimento de onda de $1.000 \mathrm{~nm}$ : observam-se os mesmos picos de intensidade emissiva nos comprimentos de onda acima de $700 \mathrm{~nm}$, na região do infravermelho, e intensidades crescentes na região do ultravioleta (abaixo de $400 \mathrm{~nm}$ ), com comportamento estável nos comprimentos de luz visível.

Vale ressaltar que a emissão de radiação no comprimento do ultravioleta, apesar de modesta, é fator decisivo para a adoção das lâmpadas de xenônio em simuladores solares, pois sua curva se assemelha ao perfil emissivo solar. Para aproximar ainda mais a irradiação da lâmpada à solar, seria necessário a aplicação de filtros, a fim de eliminar os picos de radiação observados na região do infravermelho. Porém, no projeto em questão, desenvolvido para aplicações térmicas, a potência total irradiada é mais importante do que a fidelidade ao perfil emissivo solar e, desta forma, descartou-se o uso de filtros, pois isso significaria a perda da potência inerente aos comprimentos de onda filtrados.

No teste para avaliar o fluxo de calor no foco do concentrador e o fator de concentração do aparato, as grandezas medidas são a vazão volumétrica (L/h) e as temperaturas do fluido na entrada e na saída da cavidade receptora $\left({ }^{\circ} \mathrm{C}\right)$, usadas para estimar a quantidade de energia que adentra a cavidade por unidade de tempo, ou seja, a potência térmica fornecida pelo simulador solar no foco do concentrador, através da $1^{\underline{a}}$ Lei da Termodinâmica.

Antes de iniciar a tomada de dados, uma etapa muito importante do teste é o alinhamento e posicionamento minuciosos dos componentes que integram o arranjo experimental, a fim de garantir que feixes de raios luminosos paralelos atinjam o refletor parabólico, sejam concentrados em uma pequena região de alta densidade 
luminosa e que este foco se localize no interior da cavidade receptora, maximizando a quantidade de energia absorvida pelo circuito de água. Após diversas aferições e testes preliminares, a configuração final do arranjo experimental é apresentada na Figura 6.2:

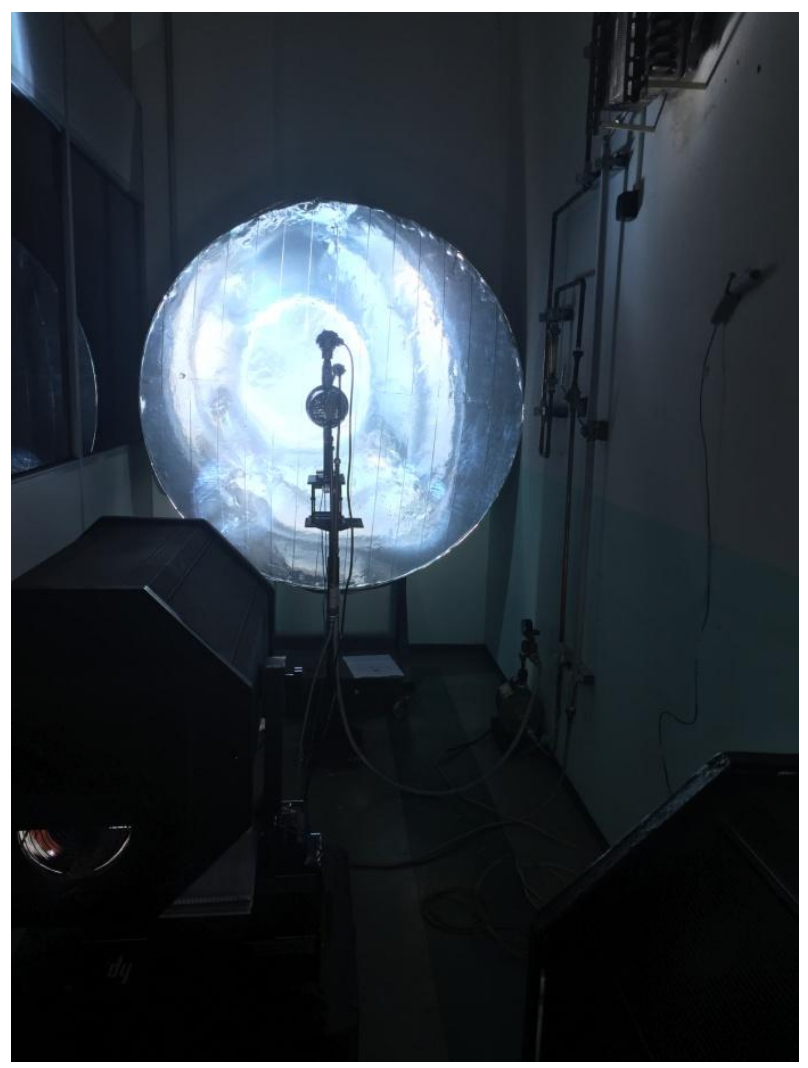

Figura 6.2 - Configuração final do arranjo experimental após etapa de alinhamento e posicionamento de seus componentes

O procedimento deste teste também é bastante simples: a motobomba do circuito de água é ligada e a vazão de operação do experimento é escolhida ajustando-se a abertura da válvula acoplada à motobomba até que se atinja o valor desejado no visor do rotâmetro. Aguardam-se 30 minutos até que todas as bolhas do circuito de água tenham sido eliminadas.

Com todos os medidores devidamente instalados e testados, os dois Sky Search Lights e o exaustor acoplado ao trocador de calor são ligados, iniciando com isso a 
tomada de dados do instante 0s. Para cada vazão volumétrica definida, os valores das temperaturas são coletados visualmente e registrados em uma planilha Excel pelo operador a cada 30 s, totalizando $1 \mathrm{~h}$ de teste, a fim de garantir que o regime permanente seja atingido.

Os resultados obtidos quando atingido o regime permanente no teste realizado à vazão volumétrica de $200 \mathrm{~L} / \mathrm{h}\left(5,56 \times 10^{-5} \mathrm{~m}^{3} / \mathrm{s}\right)$ são apresentados na Tabela 6.1:

Tabela 6.1 - Resumo dos parâmetros medidos e calculados para regime permanente no teste 1

\begin{tabular}{|c|c|c|c|c|c|c|}
\hline$\dot{\boldsymbol{V}}(\mathbf{L} / \mathbf{h})$ & $\dot{\boldsymbol{V}}\left(\mathbf{m}^{3} / \mathbf{s}\right)$ & $\mathbf{T}_{\mathbf{1}}\left({ }^{\circ} \mathbf{C}\right)$ & $\mathbf{T}_{\mathbf{2}}\left({ }^{\circ} \mathbf{C}\right)$ & $\boldsymbol{\Delta} \mathbf{T}$ & $\mathbf{Q}(\mathbf{W})$ & $\boldsymbol{\eta}_{\text {concentração }}$ \\
\hline $200 \pm 13$ & $(5,56 \pm 0,36) \mathrm{E}-05$ & $45,3 \pm 0,1$ & $40,2 \pm 0,1$ & $5,1 \pm 0,2$ & $1183 \pm 84$ & $87 \% \pm 6 \%$ \\
\hline
\end{tabular}

Na Figura 6.3 se observa a evolução da diferença entre as temperaturas do fluido na entrada e na saída da cavidade receptora até se estabelecer o regime permanente, quando $\Delta \mathrm{T}$ atinge $5,1^{\circ} \mathrm{C}$ :

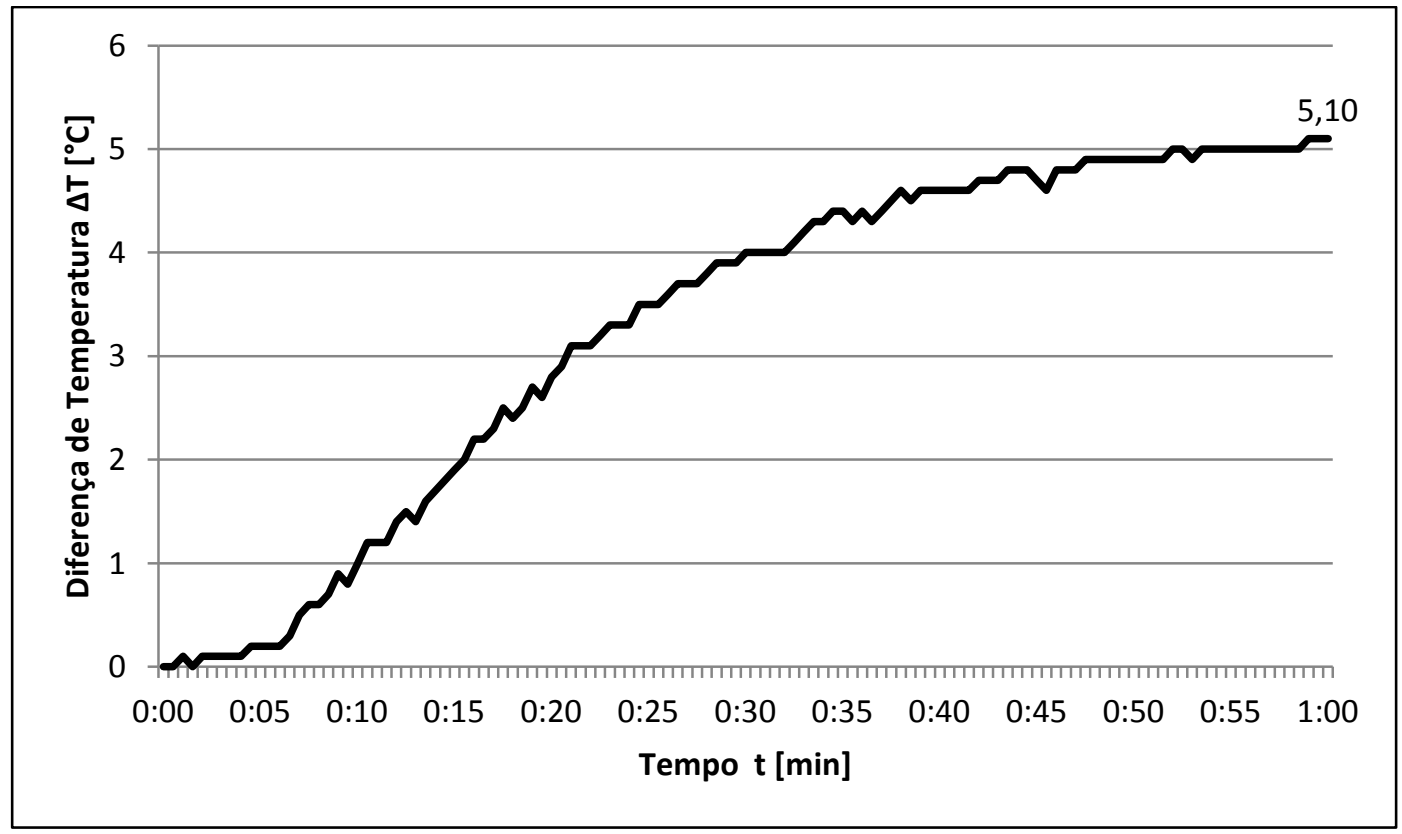

Figura 6.3 - Diferença de temperatura da água na entrada e na saída da cavidade receptora à $200 L / h$ 
Finalmente, a diferença de temperatura medida ao longo do teste é usada para avaliar o fluxo de calor no foco do concentrador através da $1^{\text {a }}$ Lei da Termodinâmica: $\dot{Q}=(\rho . \dot{V}) \times c \times \Delta T$, onde $\rho_{\text {água }}=997 \mathrm{~kg} / \mathrm{m}^{3}$ e $c_{\text {água }}=4.186 \mathrm{~J} /(\mathrm{kg} . \mathrm{K}):$

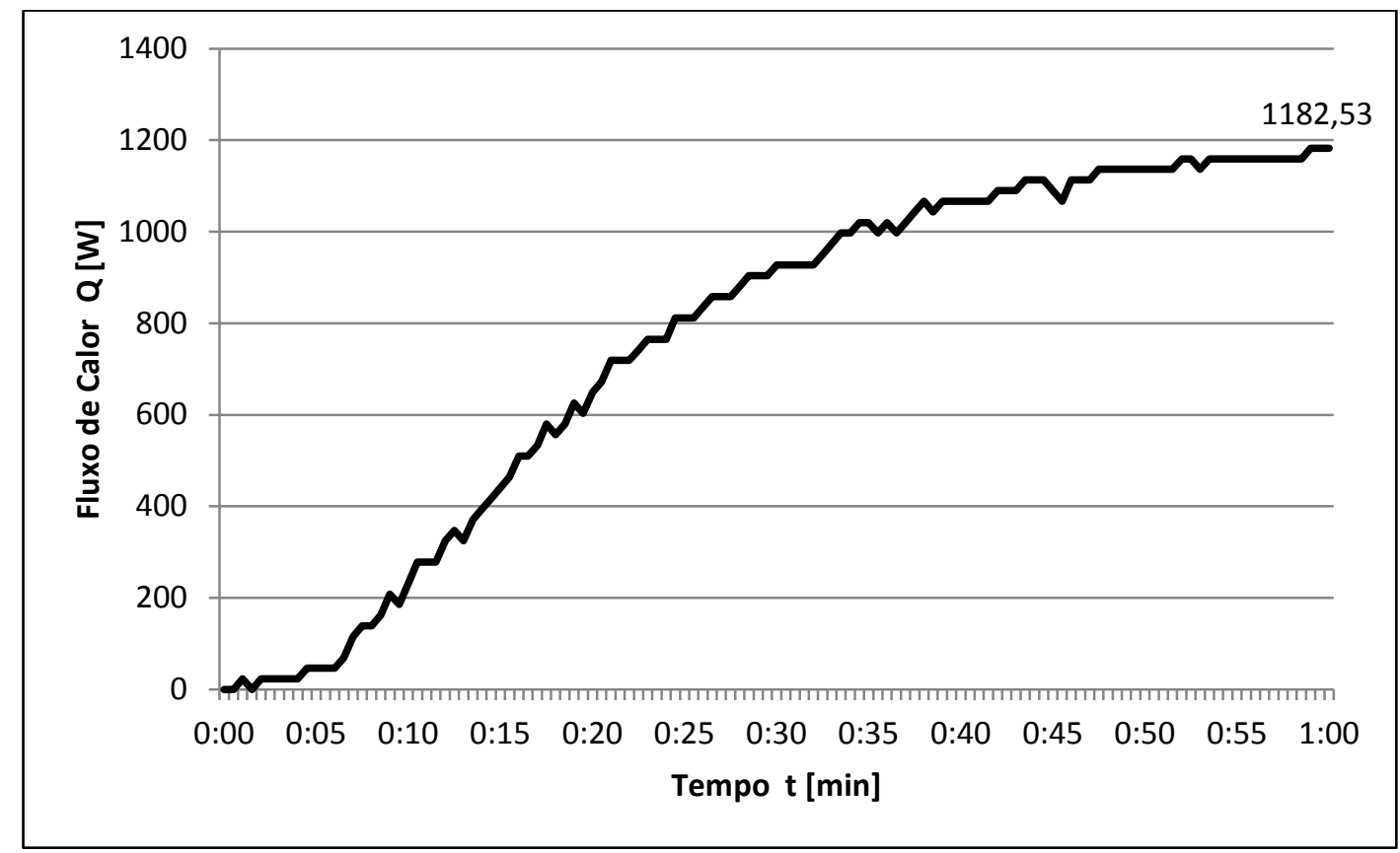

Figura 6.4 - Fluxo de calor no circuito de água em função do tempo

Na Figura 6.4 observa-se que a potência térmica fornecida pelo simulador solar no foco do concentrador atinge $1.182,53 \mathrm{~W}$ no regime permanente, excedendo 0 objetivo inicial deste projeto que previa um fluxo de calor máximo de $1 \mathrm{~kW}$.

A eficiência de concentração do concentrador parabólico $\left(\dot{\eta}_{\text {concentração }}\right)$, calculada através da equação 5.10 utilizando-se a média dos últimos 10 valores de $\dot{Q}$ obtidos no teste 1 , atinge $87 \%$. Este valor está diretamente relacionado à qualidade construtiva do simulador solar concentrador, ou seja, de todos os raios luminosos que atingem o refletor parabólico, apenas 13\% não chegam ao foco do concentrador por irregularidades na superfície refletora, ou por desvios na direção de incidência da luz e na geometria parabólica. 
Já os resultados obtidos quando atingido o regime permanente no teste realizado à vazão volumétrica de $100 \mathrm{~L} / \mathrm{h}\left(2,78 \times 10^{-5} \mathrm{~m}^{3} / \mathrm{s}\right)$ são apresentados na Tabela 6.2:

Tabela 6.2 - Resumo dos parâmetros medidos e calculados para regime permanente no teste 2

\begin{tabular}{|c|c|c|c|c|c|}
\hline$\dot{\boldsymbol{V}}(\mathbf{L} / \mathbf{h})$ & $\dot{\boldsymbol{V}}\left(\mathbf{m}^{\mathbf{3}} / \mathbf{s}\right)$ & $\mathbf{T}_{\mathbf{1}}\left({ }^{\circ} \mathbf{C}\right)$ & $\mathbf{T}_{\mathbf{2}}\left({ }^{\circ} \mathbf{C}\right)$ & $\boldsymbol{\Delta} \mathbf{T}$ & $\mathbf{Q}(\mathbf{W})$ \\
\hline $100 \pm 13$ & $(2,78 \pm 0,36) \mathrm{E}-05$ & $47,0 \pm 0,1$ & $41,2 \pm 0,1$ & $5,8 \pm 0,2$ & $672 \pm 89$ \\
\hline
\end{tabular}

Analisando os resultados, é possível constatar que, como a diferença de temperatura da água na entrada e na saída da cavidade receptora não varia muito entre os testes, o fluxo de calor no circuito de água é diretamente proporcional à vazão volumétrica do fluido, de acordo com a $1^{\text {a }}$ Lei da Termodinâmica:

$$
\downarrow \dot{Q}=(\rho \cdot \downarrow \dot{V}) \times c \times \Delta T
$$

O fato da diferença de temperatura $\Delta T$ não aumentar significativamente com a redução da vazão de água pode ser justificado pela análise do circuito elétrico equivalente usado no balanço térmico da cavidade receptora (Anexo A.3). Nele, é possível constatar que o coeficiente de convecção do ar $\left(h_{\text {ext }}\right)$ é muito menor do que o coeficiente de convecção no interior da cavidade, o que faz com que a perda por convecção para o ambiente externo domine o balanço térmico neste teste, reduzindo a parcela de energia que é absorvida pela água. Esta perda elevada deve ser investigada e quantificada com mais detalhes.

A fim de avaliar também a temperatura máxima que se atinge no interior da cavidade receptora com o simulador solar construído, esvaziou-se o circuito de água para dar início a uma nova tomada de dados, assim que as fontes de luz fossem ligadas. Os valores da temperatura interna da cavidade são novamente coletados visualmente e 
registrados em uma planilha Excel pelo operador, desta vez a cada minuto, totalizando $2 \mathrm{~h} 40 \mathrm{~min}$ de teste, tempo necessário para que a temperatura se estabilize.

O resultado obtido é apresentado na Figura 6.5, onde se destaca a temperatura máxima atingida no interior da cavidade após $2 \mathrm{~h} 40 \mathrm{~min}$ de teste igual a $242,81^{\circ} \mathrm{C}$ :

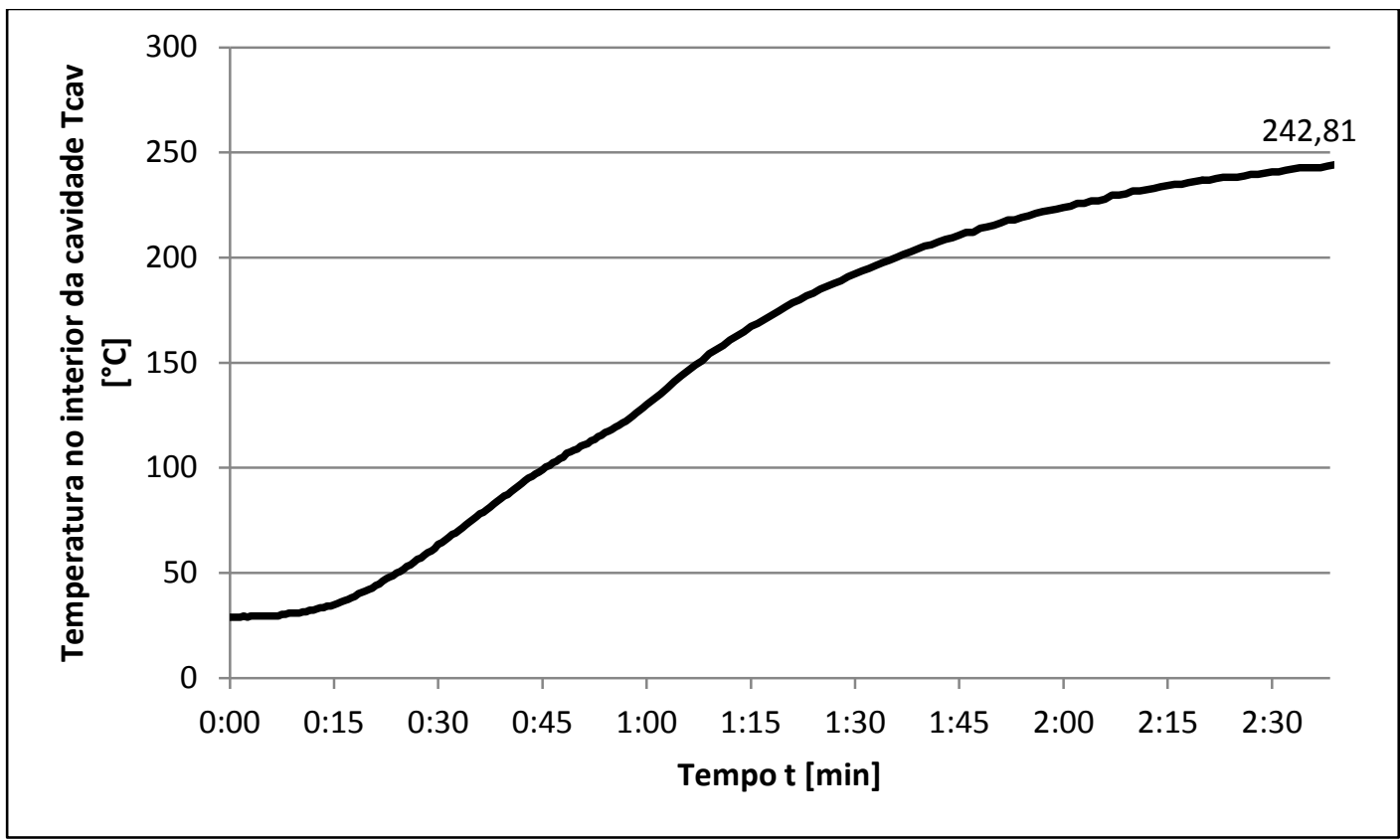

Figura 6.5 - Temperatura no interior da cavidade receptora em função do tempo

As distribuições de temperatura nas superfícies do concentrador parabólico e da cavidade receptora ao final do teste foram capturadas com uma câmera de infravermelho e são apresentadas na Figura 6.6. Observa-se que, devido à parcela de energia radiativa capturada pela imagem, a temperatura máxima da cavidade percebida pela câmera ultrapassa $270^{\circ} \mathrm{C}$ : 

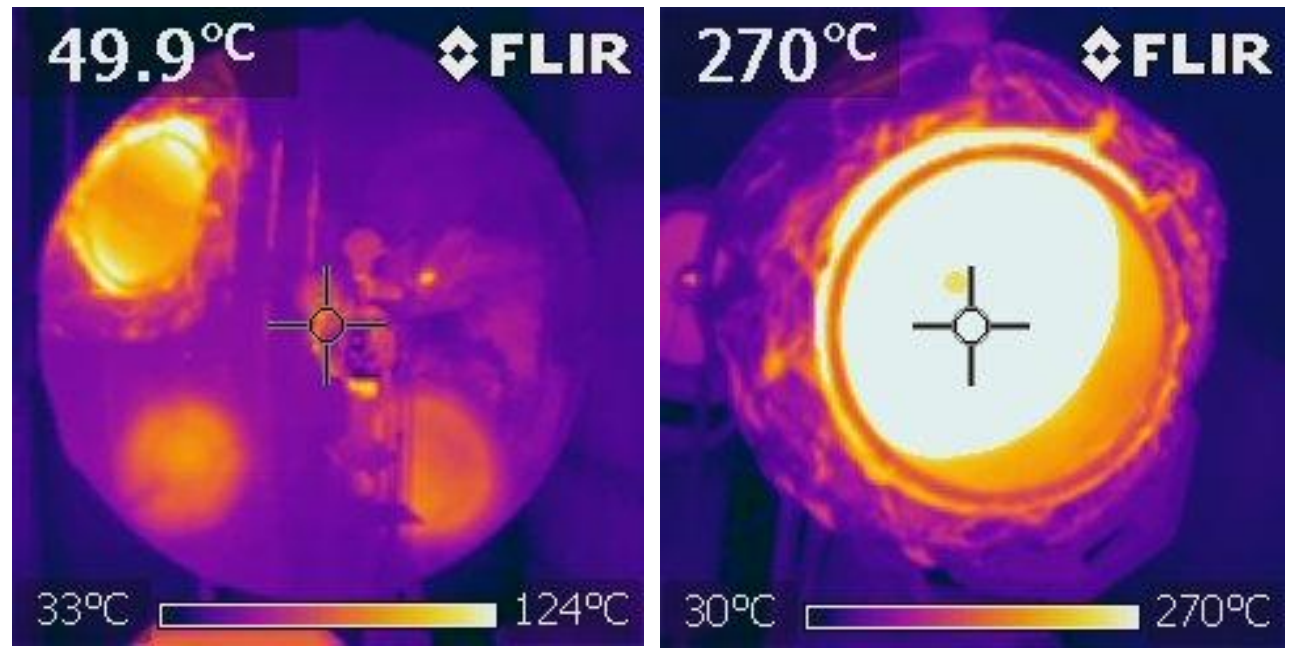

Figura 6.6 - Distribuição de temperatura nas superfícies do concentrador e da cavidade receptora após os testes 


\section{CONCLUSÃO}

O projeto desenvolvido nesta dissertação de Mestrado pode ser considerado bem sucedido uma vez que atingiu todos os seus objetivos, geral e específicos, ao finalizar a construção e os testes do novo simulador solar concentrador da Escola Politécnica da USP.

A fim de avaliar de forma concreta o retorno do investimento realizado e da mobilização de uma equipe qualificada, alguns critérios foram estabelecidos no princípio e avaliados ao fim do projeto para confirmar o seu sucesso:

1. Os parâmetros medidos devem ser próximos aos valores estimados (Tabela 7.1), garantindo confiabilidade equivalente à dos principais exemplares de simuladores solares no mundo, reproduzindo a radiação concentrada do Sol com precisão.

Tabela 7.1 - Parâmetros do simulador solar (estimados X medidos)

\begin{tabular}{|c|c|c|c|}
\hline Parâmetros & Estimativa & Medição & Desvio \\
\hline Potência térmica fornecida (kW) & 1 & 1,182 & $+18,2 \%$ \\
Concentração de radiação ("sóis") & 800 & 941 & $+17,6 \%$ \\
\hline
\end{tabular}

Este critério objetivo foi satisfeito, de acordo com os resultados dos testes realizados no simulador solar construído.

2. Os estudos nesta frente de pesquisa devem se intensificar dentro e fora do laboratório, fazendo com que o simulador solar seja altamente requisitado em âmbito nacional e passe a operar frequentemente. 
Este critério subjetivo foi parcialmente satisfeito, uma vez que, como já mencionado, o laboratório SISEA desenvolve atualmente estudos teóricos que envolvem a reforma de metano, a gaseificação de biomassa e o aquecimento de óleo para um ciclo Rankine através da energia concentrada do Sol. Todas essas pesquisas têm grande interesse na utilização do simulador solar concentrador para aferição prática de suas estimativas teóricas. Porém, nenhuma parceria externa foi firmada até o momento, apesar do interesse demonstrado por diversos pesquisadores que visitaram o laboratório ao longo do projeto. Espera-se que, com a divulgação deste projeto através de publicações em fóruns acadêmicos, a procura se intensifique, além da replicação deste modelo de simulador solar de baixo custo em outros centros de pesquisa.

Desde o princípio, o projeto do simulador solar priorizou a facilidade de construção e operação, buscando uma configuração inovadora que se utilizasse de equipamentos padronizados e comercializados em larga escala, o que ainda reduziu o prazo e o investimento para sua montagem. Desta ótica, para o que se propôs, o modelo desenvolvido foi um sucesso. Porém, algumas lições foram aprendidas e melhoria propostas para o aperfeiçoamento do aparato em projetos futuros, uma vez que existam verba disponível e equipe capacitada para tal:

- utilização da metalização a alto vácuo para revestimento do refletor parabólico, a fim de melhorar a refletância e o acabamento da superfície, aumentando com isso a parcela de energia luminosa refletida na direção do foco;

- troca dos refletores internos dos Sky Search Lights a fim de garantir a saída de raios luminosos paralelos das fontes; 
- troca das lâmpadas de xenônio de 4.000W dos Sky Search Lights por lâmpadas de potência igual ou superior de fabricantes mais renomados no mercado, que possuam especificações técnicas mais precisas, resultados de testes aos quais as lâmpadas foram submetidas e demais informações disponíveis ao consumidor;

- utilização de filtros de radiação infravermelha para aplicação do simulador solar em experimentos na área de química solar de reações;

- aquisição de novas fontes luminosas para expandir a potência térmica máxima fornecida pelo simulador solar;

- redução da cavidade receptora e do foco para minimizar as perdas;

- sistema de monitoramento (câmeras) e acionamento à distância do simulador solar, evitando o contato do operador com a alta radiação. 


\section{BIBLIOGRAFIA}

Alxneit I, Dibowski G. R12.5 Solar Simulator Evaluation Report - Project SFERA. Solar Facilities for the European Research Area. 2011.

Andrews, D. G. An Introduction to Atmospheric Physics. New York: Cambridge University Press. Vol. 2. 2010.

Bode S. J, Gauche P, Landman W. The Design and Testing of a Small Scale Solar Flux Measurement System for Central Receiver Plant. Centre for Renewable and Sustainable Energy Studies - Stellenbosch University. 7p. 2012.

Clifford K. Ho, Siri S. K. A Flux Mapping Method for Central Receiver Systems. ASME 2011- 5th International Conference on Energy Sustainability. ES2011-54497. 2011.

ClimaGeo - Comunidade de Climatologia. Disponível em: <http://climageo.no. comunidades.net>.

Codd D. S, Carlson A, Rees J, Slocum A. H. A Low Cost High Flux Solar Simulator. Science Direct - Solar Energy. Vol. 84, pp. 2202-2212. 2010.

CRESESB - Centro de Referência para Energia Solar e Eólica Sérgio de Salvo Brito. Disponível em: <http://www.cresesb.cepel.br/principal.php>.

Dong X, Ashman P. J, Nathan G. J. A High-Flux Solar Simulator System for Investigating the Influence of Concentrated Solar Radiation on Turbulent Reacting Flows. $50^{\text {th }}$ Annual Conference - Australian Solar Energy Society (Australian Solar Council), Melbourne. 2012. 
Duffie J. A, Beckman W. A. Solar Engineering of Thermal Processes. John Wiley \& Sons Inc., $4^{\text {th }}$ edition. 2013.

Erickson B. M. Characterization of the University of Florida Solar Simulator and an Inverse Solution for Identifying Intensity Distributions from Multiple Flux Maps in Concentrating Solar Applications. Master of Science Thesis, University of Florida. 2012.

IPT - Instituto de Pesquisas Tecnológicas. Novo Simulador Solar. Disponível em: <http://www.ipt .br/noticia/565-novo_simulador_solar.htm>.

Meier A, Sattler C. Solar Fuels from Concentrated Sunlight. Switzerland: Burger Druck GmbH, 36p. 2009.

Nigro L. G. Concepção de um Receptor de Cavidade para Concentração de Energia Solar para Aplicação em Reatores Químicos. Dissertação de Mestrado em Engenharia, Universidade de São Paulo. 2015.

Pereira E, Martins F, Abreu S, Rüther R. Atlas Brasileiro de Energia Solar. 1aㅡ edição, 64p. 2006.

Petrash J, Coray P, Meier A, Brack M, Häberling P, Wuillemin D, Steinfeld A. A Novel 50 kW 11.000 Suns High-Flux Solar Simulator Based on an Array of Xenon Arc Lamps. Journal of Solar Energy Engineering. Vol. 129, pp. 405-11. 2007.

Piatkowski N, Steinfeld A. Solar Gasification of Carbonaceous Waste Feedstocks in a Packed-Bed Reactor - Dynamic Modeling and Experimental Validation. AIChE Journal. Vol. 57, № 12, pp. 3522-3533. 2011.

PSI - Paul Scherrer Institut. Disponível em: <http://solar.web.psi.ch/>. 
Ribas, V. E. Estudo da Utilização de Concentradores Solares para o Processo de Gaseificação de Biomassa - Concepção de um Reator Químico Solar. Dissertação de Mestrado em Engenharia, Universidade de São Paulo. 2016.

Ribas, V. E, Rodrigues, J. R. H, Simões-Moreira, J. R. The Use of Concentrated Solar Power in the Steam-Gasification of Biomass. ENCIT $-15^{\text {th }}$ Brazilian Congress of Thermal Sciences and Engineering (ABCM), Belém. 2014.

Rodrigues, J. R. H, Ribas, V. E, Simões-Moreira, J. R. Design and Building of a Compact Solar Simulator with Radiation Concentration. ENCIT $-15^{\text {th }}$ Brazilian Congress of Thermal Sciences and Engineering (ABCM), Belém. 2014.

Sarwar J, Georgakis G, LaChance R, Ozalp N. Description and Characterization of an Adjustable Flux Solar Simulator for Solar Thermal, Thermochemical and Photovoltaic Applications. Science Direct - Solar Energy. Vol. 100, pp. 179-194. 2014.

Simões-Moreira, J. R. et al. Energias Renováveis, Geração Distribuída e Eficiência Energética. LTC Editora, 1ª edição. 2016. No prelo.

Steinfeld A, Meier A. Solar Fuels and Materials. Encyclopedia of Energy. Vol. 5, pp. 623-637. 2004.

Steinfeld A, Palumbo R. Solar Thermochemical Process Technology. In "Encyclopedia of Physical Science and Technology" (R. A. Meyers, Ed.), Academic Press, San Diego. Vol. 15, pp. 237-256. 2001.

Superior Quartz Products Inc. Xenon Short Arc Lamps. Disponível em: <http://www. sqpuv.com/PDFs/TechnicalSpecificationGuide.pdf>. 
ANEXOS 


\section{A.1 Fabricação do Refletor Parabólico Secundário}

Quando definida a configuração final do simulador solar com dupla reflexão, utilizando um único refletor parabólico secundário para a concentração dos feixes de raios paralelos provenientes das lâmpadas, iniciou-se a busca por possíveis fornecedores desse equipamento. Embora uma alternativa seria a aquisição de tal refletor pronto, vendido no mercado para aquecimento solar de água residencial, esse modelo não foi encontrado no Brasil, e a importação de um exemplar dos Estados Unidos acarretaria custos muito elevados.

Partiu-se então para a busca de um molde parabólico nas dimensões necessárias, que permitisse a fabricação do refletor a partir de alguma das diversas formas de conformação existentes. Após algumas consultas, constatou-se a existência de um molde semelhante em vidro, utilizado como concentrador de um forno solar, no Laboratório de Energia Solar da Universidade Federal da Paraíba (UFPB) liderado pelo professor doutor José Maurício Alves de Matos Gurgel, como mostrado nas imagens abaixo:
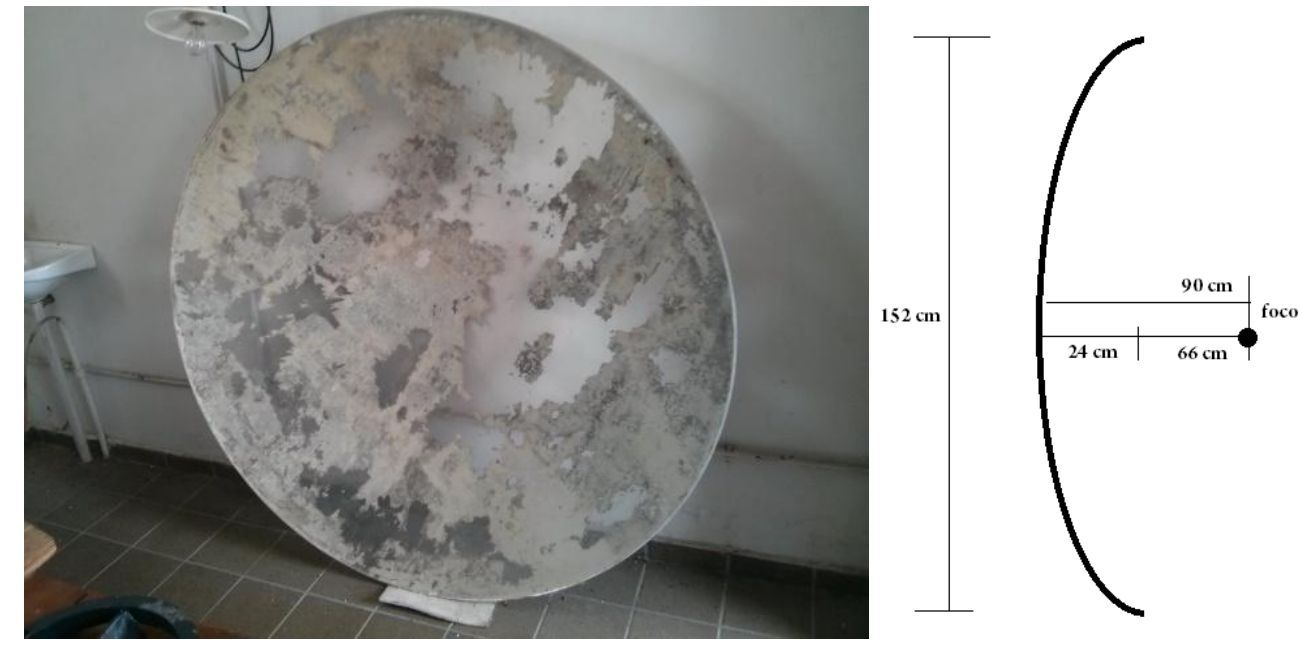

Figura A.1.1 - Molde parabólico em vidro da UFPB e suas características dimensionais 
O professor Gurgel prontamente se interessou pelo projeto do simulador solar e colocou a disposição toda a infraestrutura de seu laboratório para que os alunos envolvidos na pesquisa pudessem fabricar o refletor parabólico a partir de seu molde.

Diante desta oportunidade, a melhor alternativa encontrada, no quesito custo $X$ benefício, foi a fabricação própria do refletor parabólico através da técnica de conformação com fibra de vidro, seguindo as etapas ilustradas adiante:

- Preparação da bancada de trabalho

- Preparação do molde para conformação: limpeza e polimento

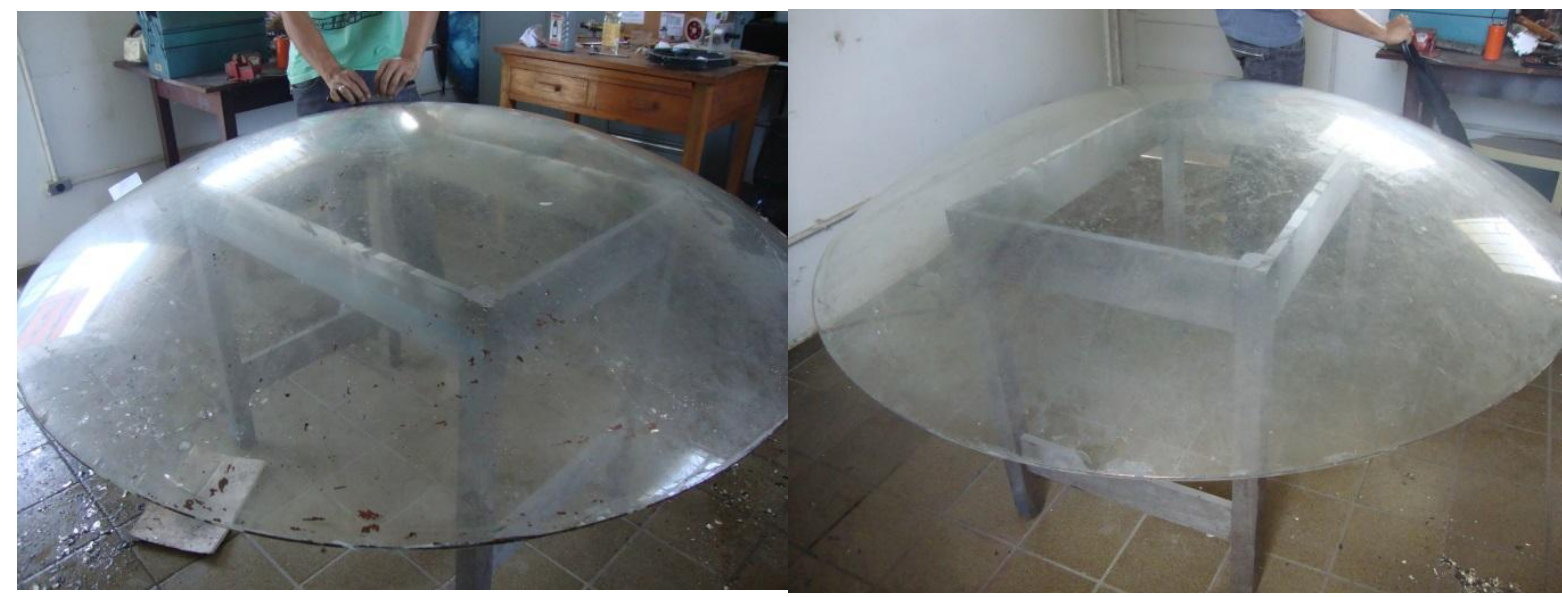

Figura A.1.2 - Processo de limpeza do molde e resultado após o polimento

- Fabricação do refletor parabólico em fibra de vidro

- Aplicação da cera desmoldante

- Aplicação da solução de Gel Coat + catalisador para garantir a qualidade da superfície do refletor fabricado (tempo de cura: 6 horas) 


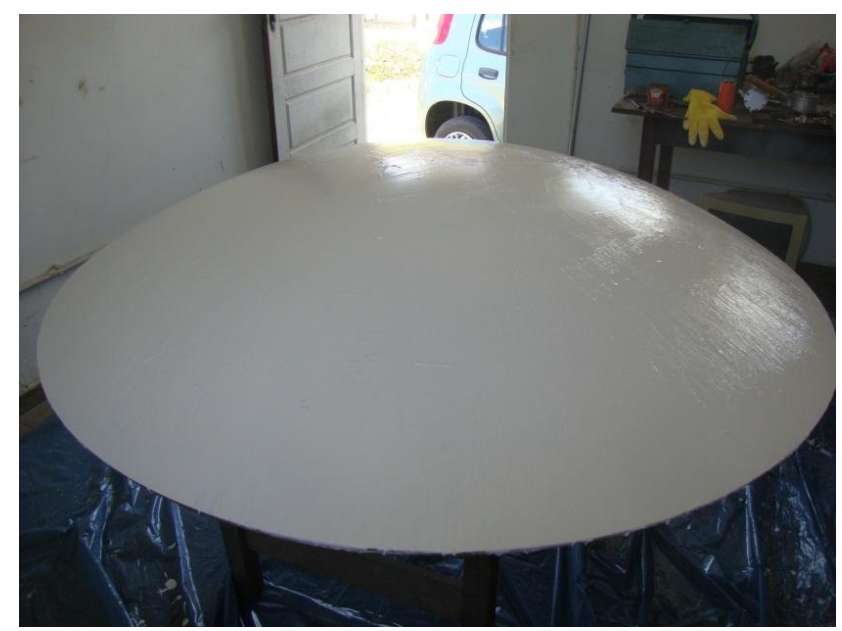

Figura A.1.3 - Resultado da aplicação de Gel Coat sobre o molde

- Aplicação de camadas intercaladas de resina e manta até atingir a espessura desejada

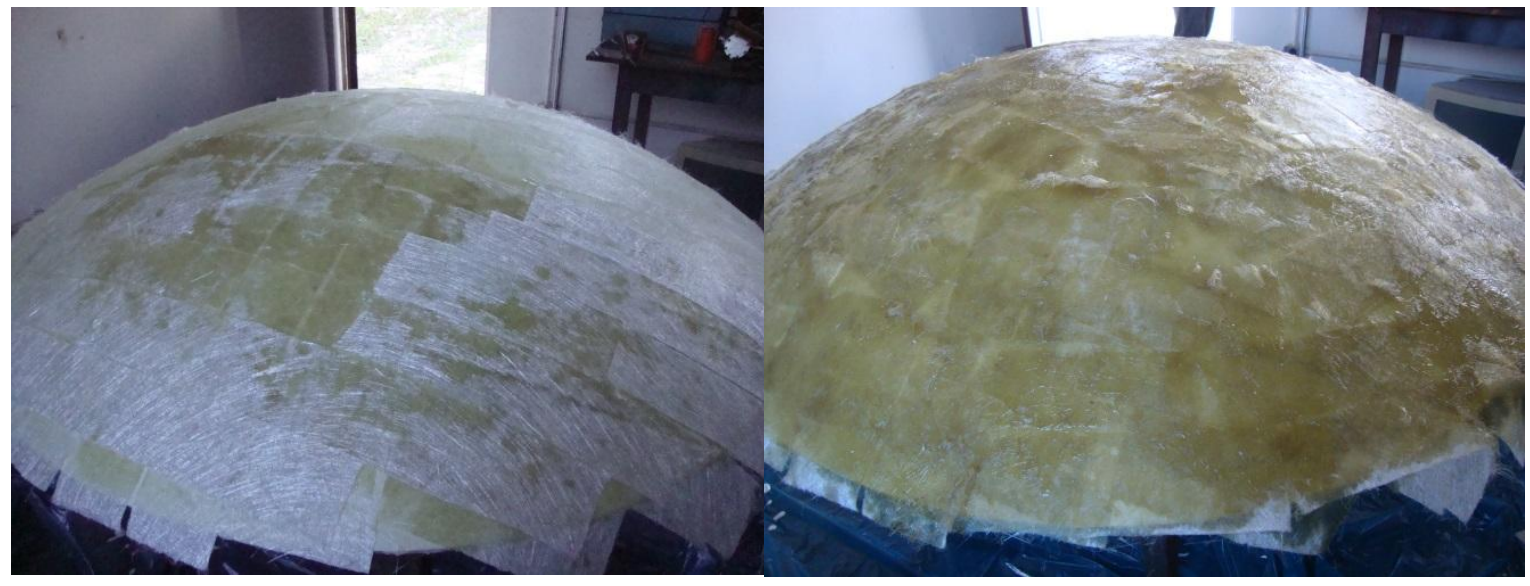

Figura A.1.4 - Sequência de aplicação das camadas de resina e manta de vidro

○ Secagem e conformação do material (tempo de cura: 24h)

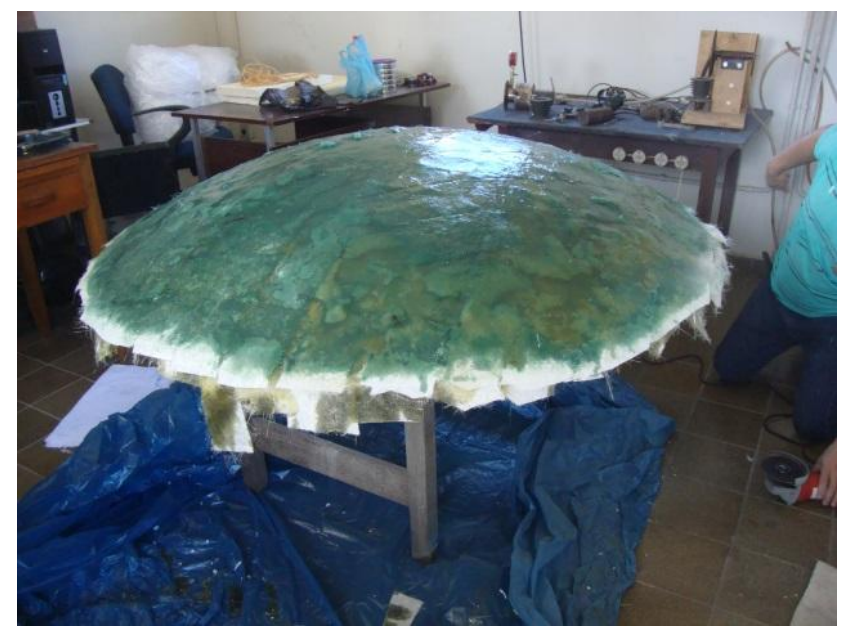

Figura A.1.5 - Etapa de cura após se atingir a espessura desejada da peça 
- Acabamento da lateral com o corte das sobras de material

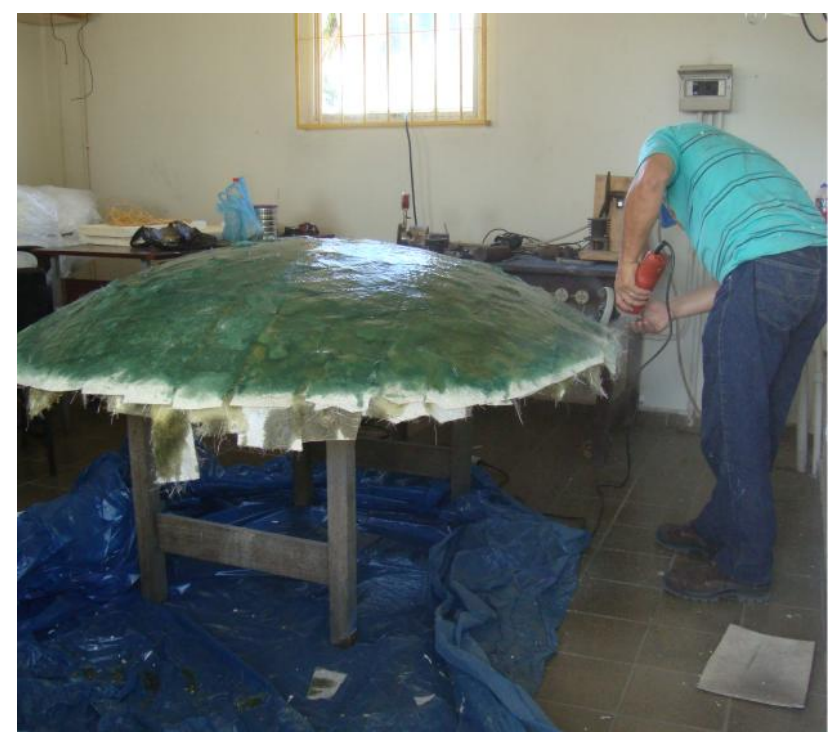

Figura A.1.6 - Apara de rebarbas e sobras de material

- Separação da peça pronta do molde

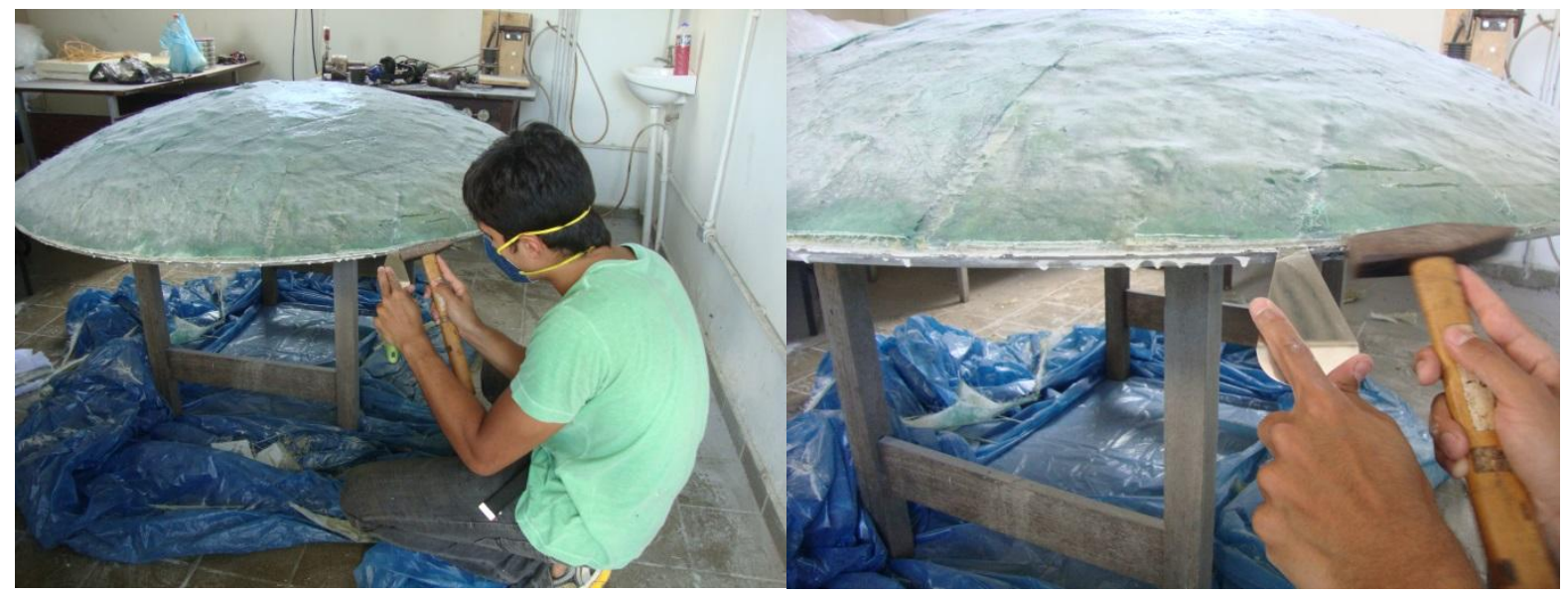

Figura A.1.7 - Etapa na qual se desenforma a peça final do molde

- Embalagem do refletor para embarque no transporte até São Paulo

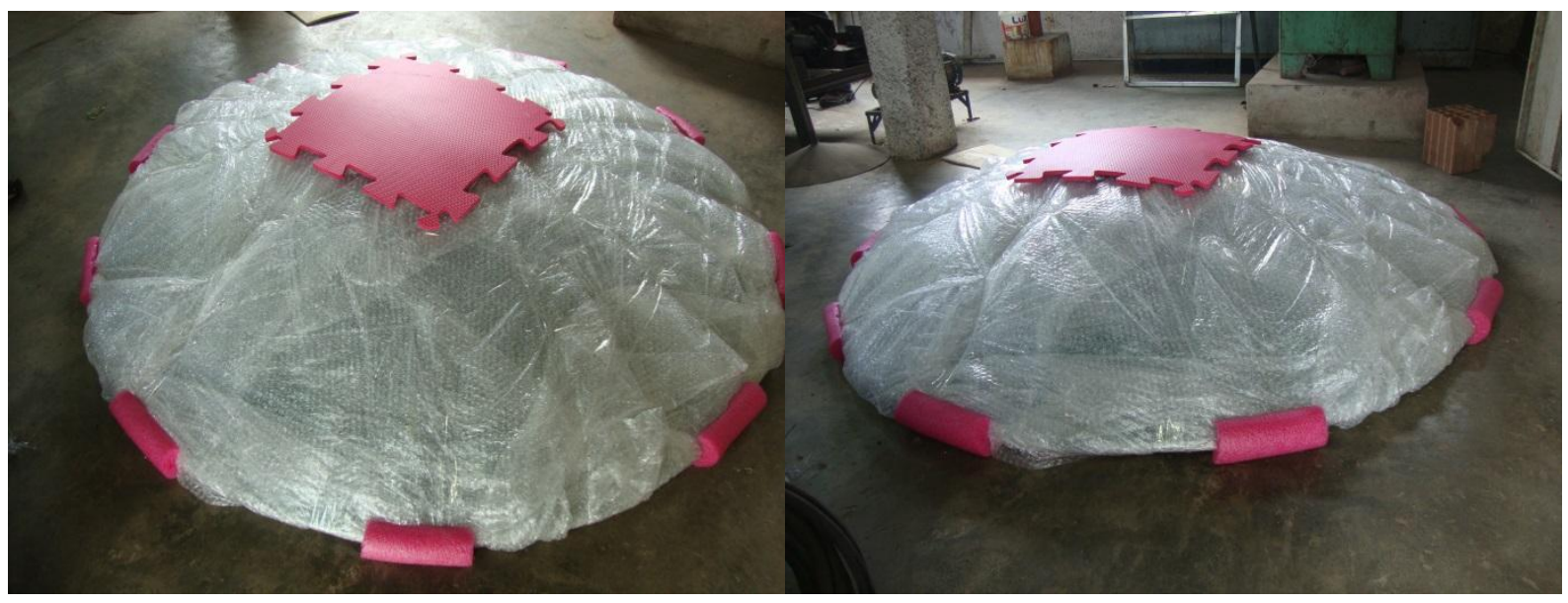




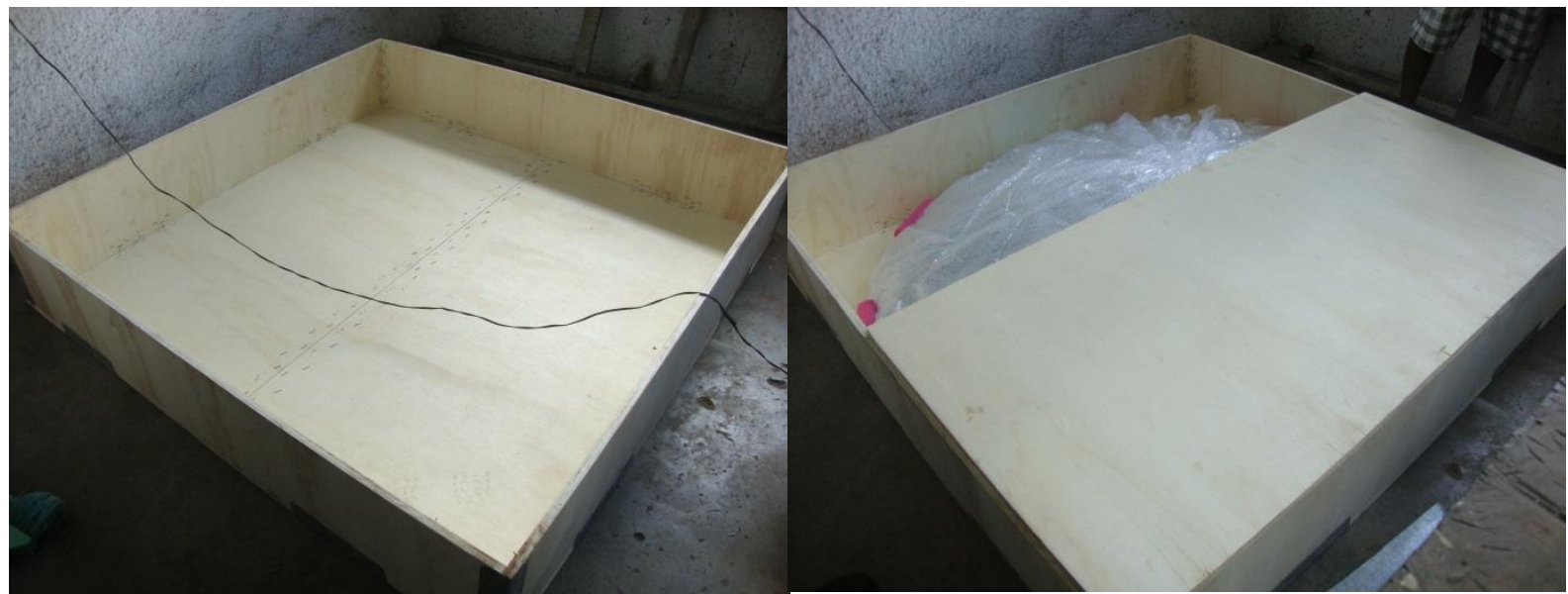

Figura A.1.8 - Embalagem cuidadosa do refletor para o transporte a São Paulo devido à fragilidade do material

Com o sucesso da fabricação do refletor parabólico, a peça foi então despachada para seu destino final - laboratório SISEA da Escola Politécnica da USP - via transporte terrestre, único meio que admitia embalagens destas dimensões. No dia 4/12/2014, a encomenda finalmente chegou a São Paulo:
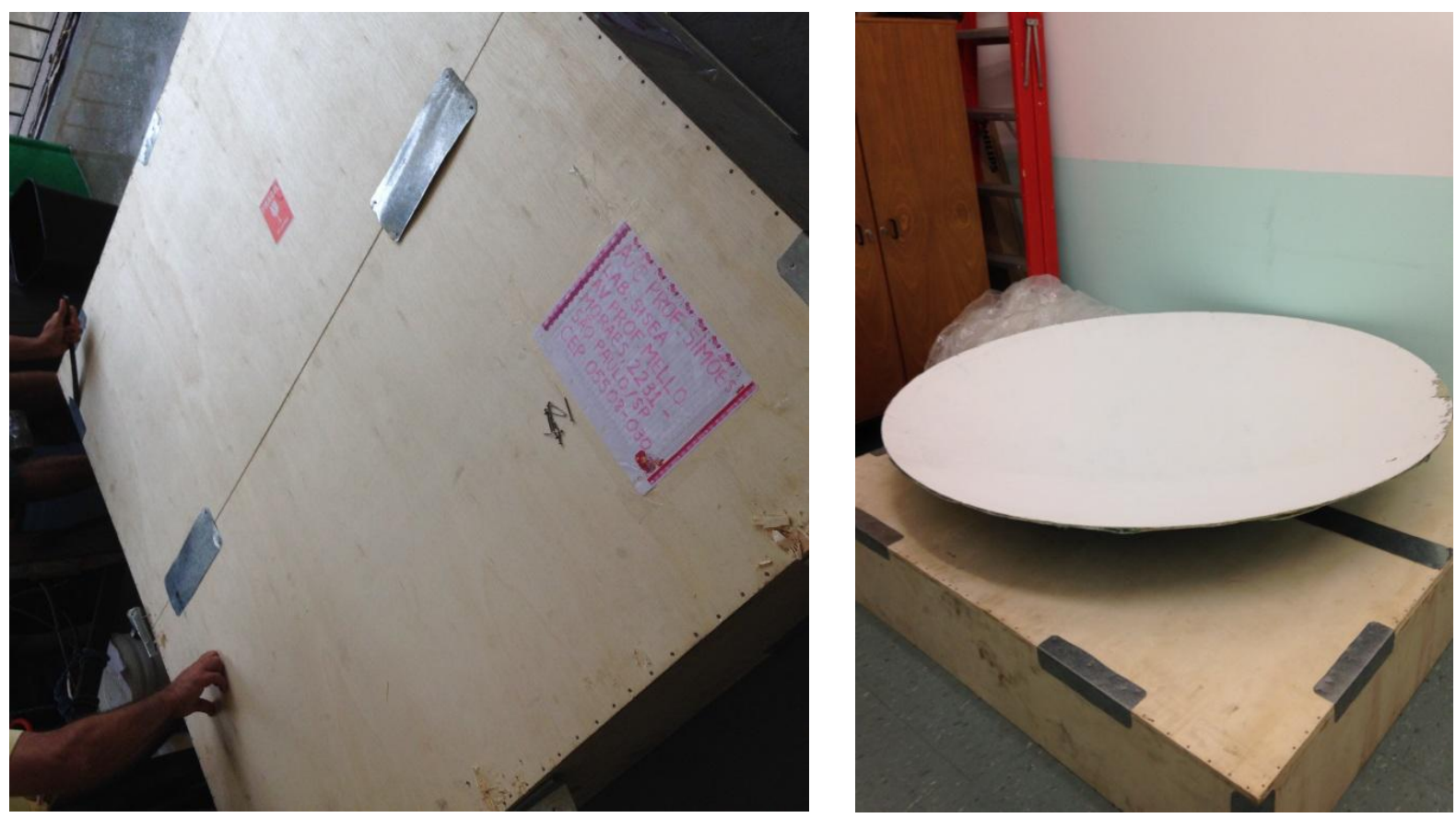

Figura A.1.9 - Chegada do refletor parabólico a São Paulo

A fim de perpetuar a geometria perfeitamente parabólica da peça fabricada no caso de novos experimentos e evitar um novo deslocamento a João Pessoa/PB na 
situação de avaria ou quebra do refletor, um contra-molde foi fabricado por segurança, seguindo o mesmo procedimento descrito acima. Dessa forma, uma cópia em fibra de vidro do molde parabólico da UFPB se encontra agora disponível no laboratório SISEA para novas aplicações, conforme mostrado na Figura A.1.10:
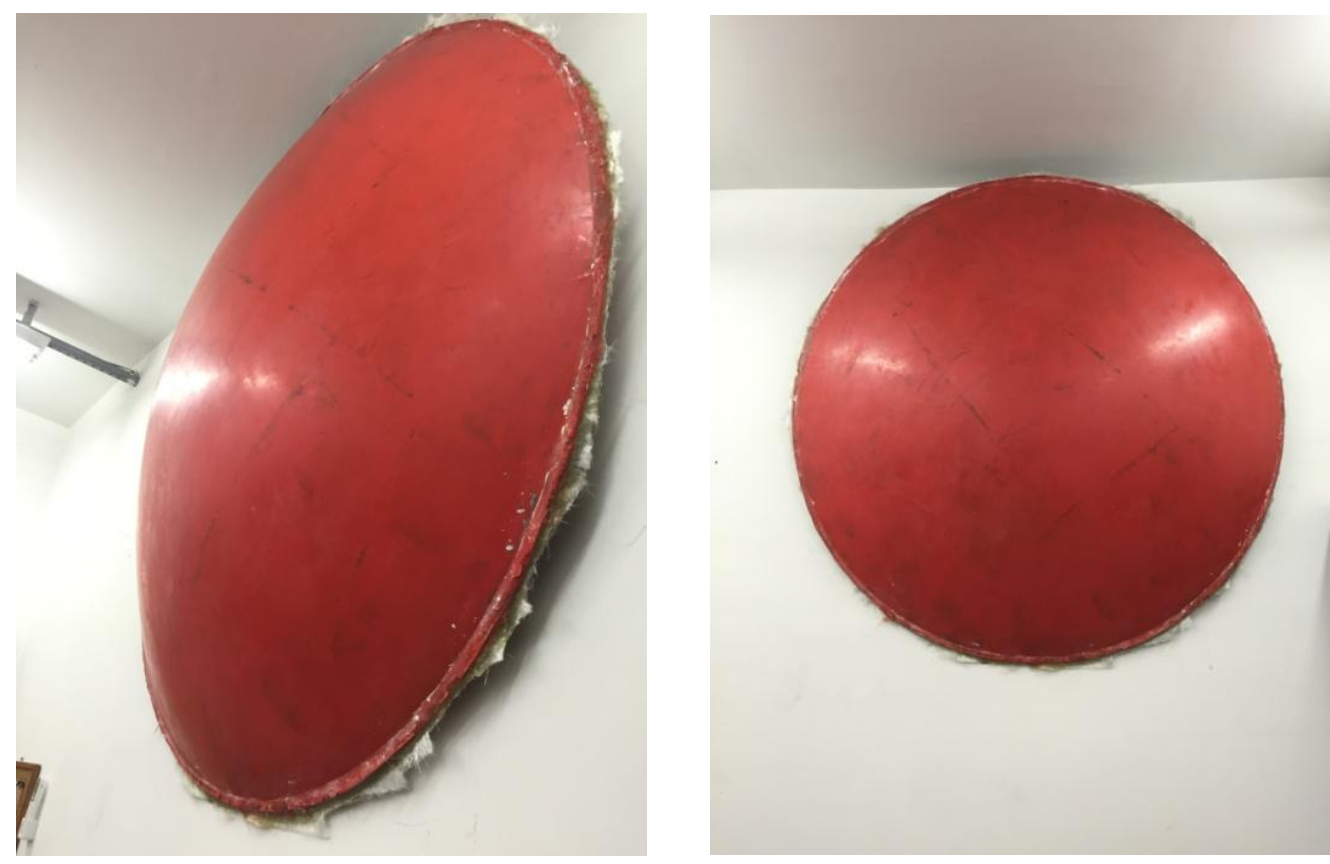

Figura A.1.10 - Cópia em fibra de vidro do molde parabólico da UFPB

Uma vez assegurada a geometria perfeitamente parabólica do refletor, foi preciso elencar alternativas para o revestimento de sua superfície interna, a fim de garantir a sua qualidade de elevada refletância direcional, assemelhando-se a um espelho. Após uma pesquisa minuciosa no mercado, quatro diferentes amostras de revestimentos foram adquiridas para testes e comparação de suas características óticas:

- Tinta base para efeito cromado - Chromenox: usada no segmento automobilístico para personalização de peças 
- Tinta para efeitos metálicos Metallik - COLORGIN: usada para decoração de ambientes internos
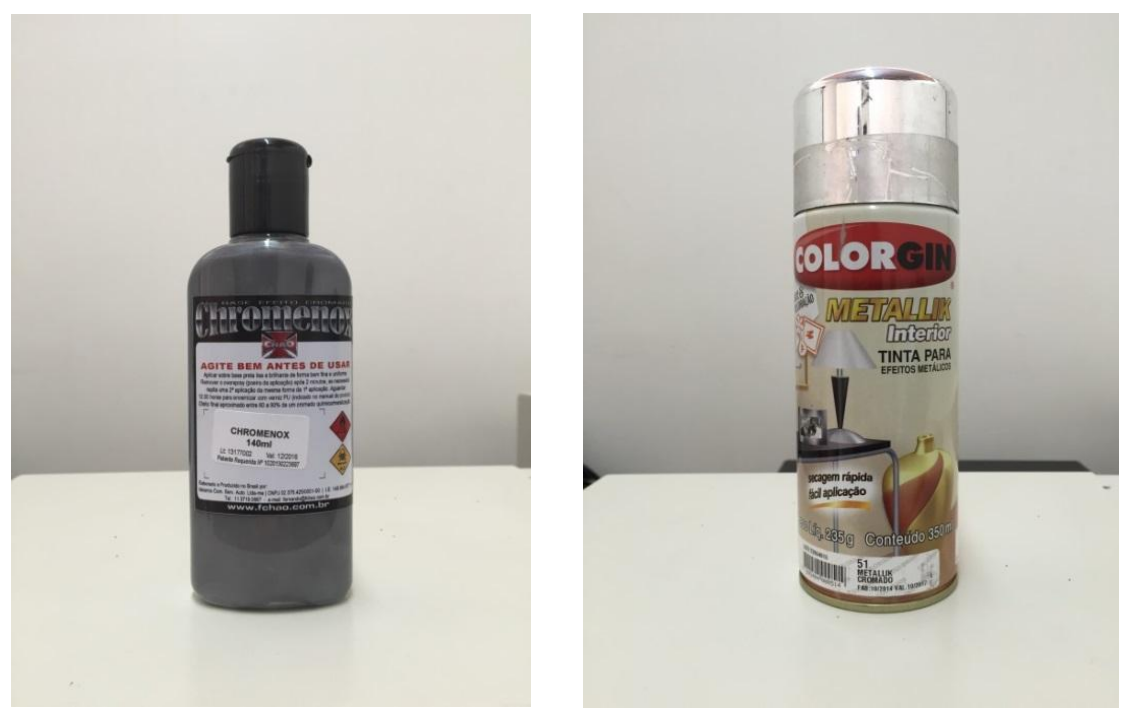

Figura A.1.11 - Tintas adquiridas para testes de refletância direcional

- Películas autoadesivas refletoras - Adespoint: usadas para diferentes fins em vidros residenciais, industriais e automotivos

- Amostra de metalização a alto vácuo - METALCLEAN: técnica usada para acabamentos em plásticos e metais, consiste em aplicar um verniz base sobre a peça e em seguida, introduzi-la em uma câmara de vácuo para a metalização, que ocorre por vaporização de alumínio

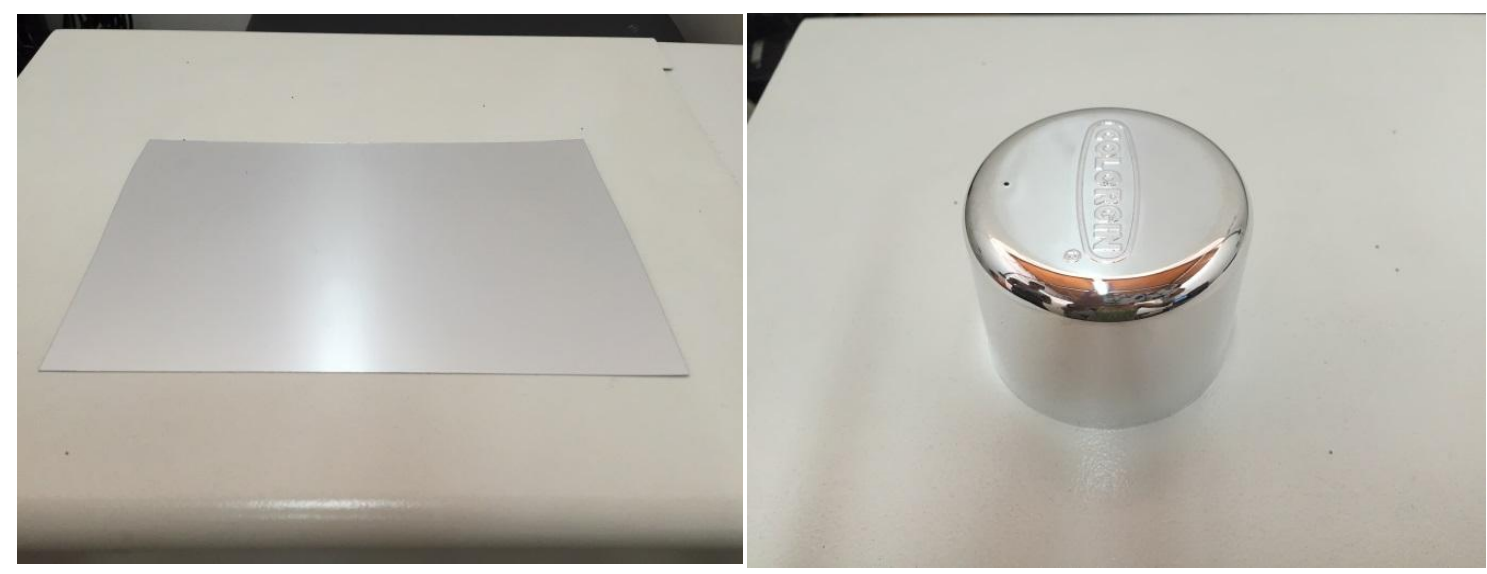

Figura A.1.12 - Amostras de película refletiva autoadesiva e de peça plástica submetida à técnica de metalização a alto vácuo 
O primeiro teste ao qual as amostras foram submetidas utilizou o modelo de espectrofotômetro UV-3101PC (UV-VIS-NIR Scanning Spectrophotometer) da marca SHIMADZU, equipamento do Laboratório de Sistemas Prediais da Escola Politécnica da USP que foi gentilmente disponibilizado pelo prof. Racine Tadeu Araújo Prado, líder do grupo de pesquisa. O espectrofotômetro é capaz de medir a refletância da superfície testada para cada comprimento de onda da radiação incidente, gerando um perfil espectral da energia radiante. O equipamento utilizado é ilustrado nas fotos abaixo:
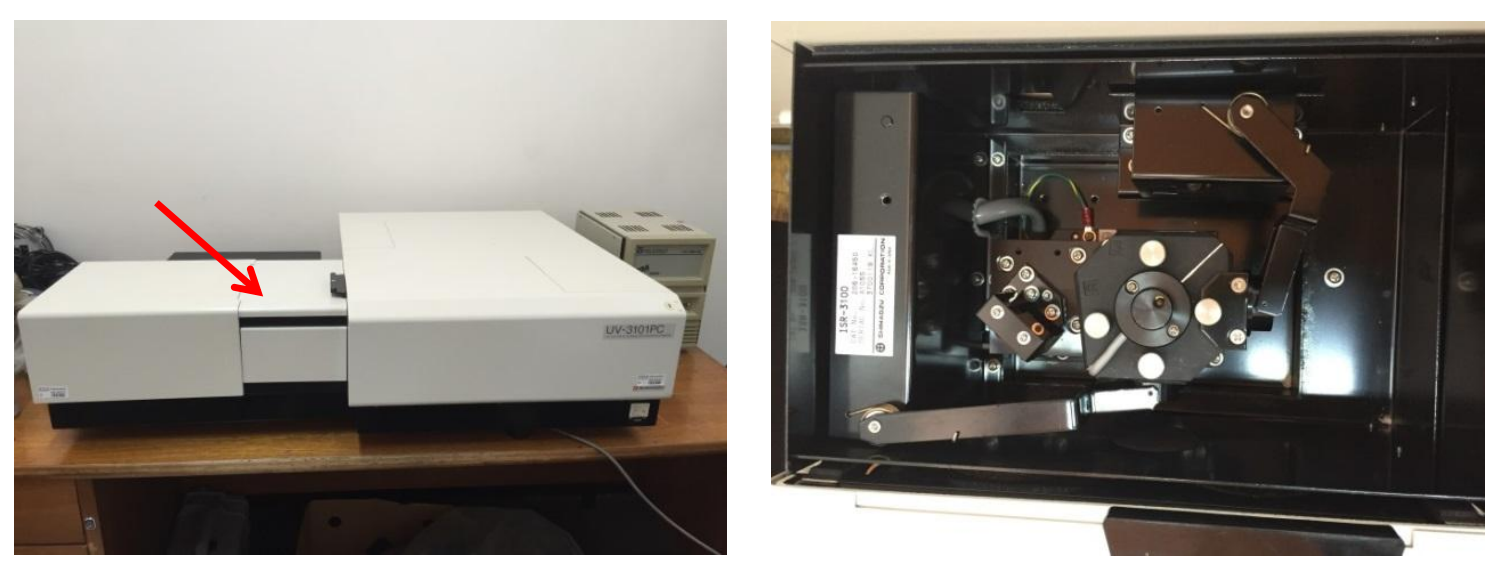

Figura A.1.13 - Espectrofotômetro UV-3101PC utilizado para teste dos revestimentos (detalhe para a configuração de sua câmara de teste)

Os dados obtidos, a primeira vista, não corresponderam ao resultado esperado. $O$ problema encontrado, após a análise cuidadosa dos dados e do manual do equipamento, foi que o espectrofotômetro é capaz de medir a refletância global, mas não a direcional, grandeza mais relevante neste estudo. Dessa forma, ainda não era possível decidir pela melhor alternativa de revestimento do refletor para aproximá-lo de um espelho.

A solução encontrada foi submeter as amostras de revestimentos a outro equipamento de teste, dessa vez o espectrômetro portátil da marca DEVICE modelo SSR-ER do Laboratório de Engenharia da Construção Civil da Escola Politécnica da 
USP que foi gentilmente disponibilizado pela profa. Kai Loh. O equipamento é ilustrado na Figura A.1.14:

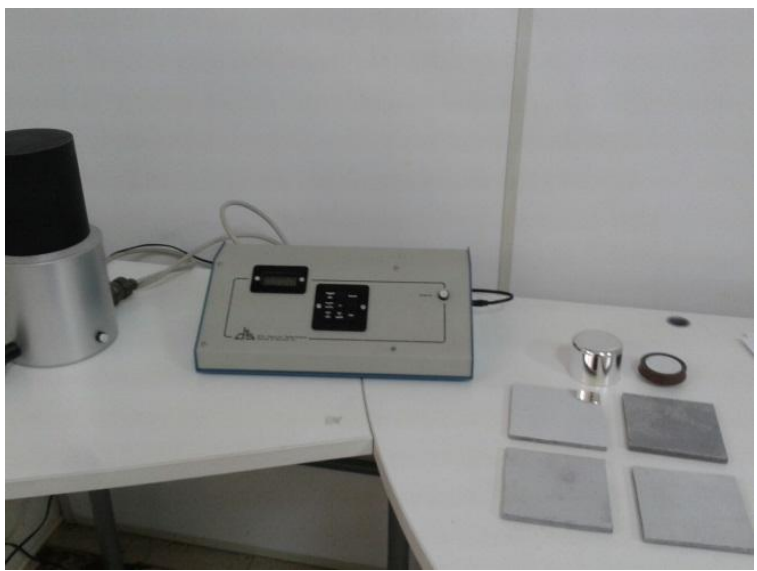

Figura A.1.14 - Espectrômetro portátil DEVICE SSR-ER utilizado para teste dos revestimentos O procedimento de teste para determinação da refletância dos diferentes revestimentos seguiu a Norma "ASTM C 1549-04": Método de Teste Padrão para Determinação de Refletância Solar Próxima à Temperatura Ambiente Usando um Refletômetro Solar Portátil, que mede a refletância hemisférica solar total. O teste é bem simples e consiste em apontar o canhão do equipamento para a superfície plana revestida pelo material a ser testado; o valor da refletância correspondente ao material é indicado no visor do equipamento instantaneamente, conforme destacado na Figura A.1.15.
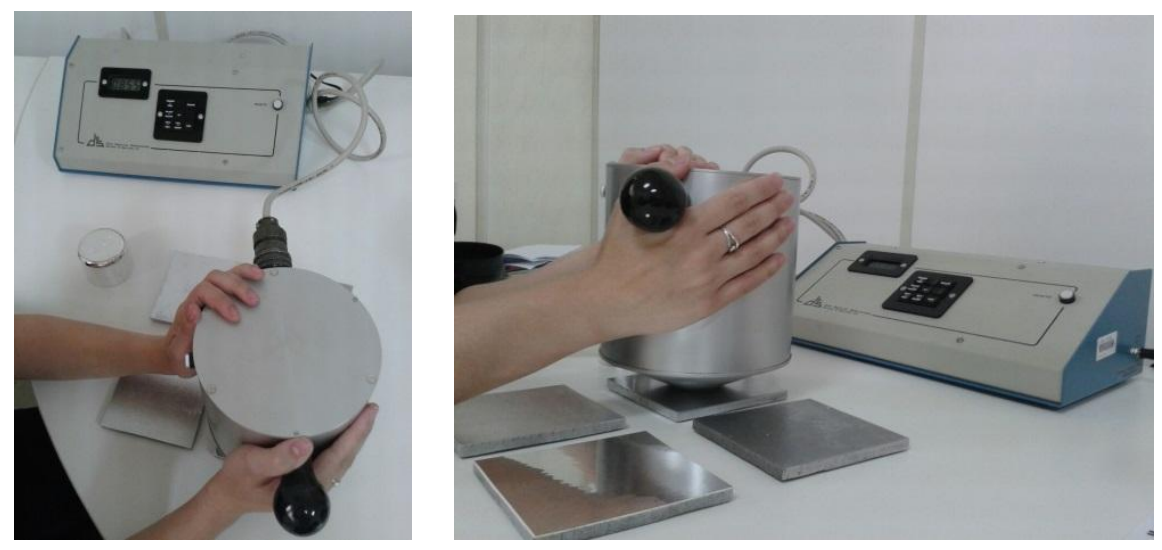

Figura A.1.15 - Procedimento de teste para determinação da refletância dos revestimentos 
Cada um dos revestimentos em análise foi submetido por cinco vezes ao teste de refletância no espectrômetro portátil e os resultados das cinco medições, assim como a média de todas elas, são apresentados na tabela abaixo:

Tabela A.1.1 - Resultados do teste de refletância dos revestimentos

\begin{tabular}{|c|c|c|c|c|c|c|}
\hline Amostras & \multicolumn{5}{|c|}{ Refletância } & Média \\
\hline Tinta spray metálica & 0,73 & 0,7 & 0,72 & 0,7 & 0,7 & 0,710 \\
\hline Tinta cromo fundo preto & 0,38 & 0,36 & 0,41 & 0,43 & 0,41 & 0,398 \\
\hline Tinta cromo fundo branco & 0,7 & 0,71 & 0,71 & 0,71 & 0,71 & 0,708 \\
\hline Película autoadesiva refletora & 0,85 & 0,85 & 0,85 & 0,85 & 0,85 & $\mathbf{0 , 8 5 0}$ \\
\hline $\begin{array}{c}\text { Amostra de metalização a alto } \\
\text { vácuo }\end{array}$ & 0,86 & 0,85 & 0,85 & 0,85 & 0,85 & 0,852 \\
\hline
\end{tabular}

A película autoadesiva refletora foi a amostra que apresentou a superfície mais homogênea; já a tinta de efeito cromado aplicada sobre um fundo preto foi a amostra que teve a maior variação entre as medições, já que a superfície não estava suficientemente homogênea.

Analisando os resultados obtidos e apresentados na Tabela A.1.1, optou-se por revestir o refletor parabólico com a película autoadesiva refletora, uma vez que a amostra apresentou uma média de refletância satisfatória em comparação aos demais materiais testados, além de ser um revestimento de fácil aplicação. $O$ resultado do revestimento do refletor parabólico é apresentado na Figura A.1.16: 


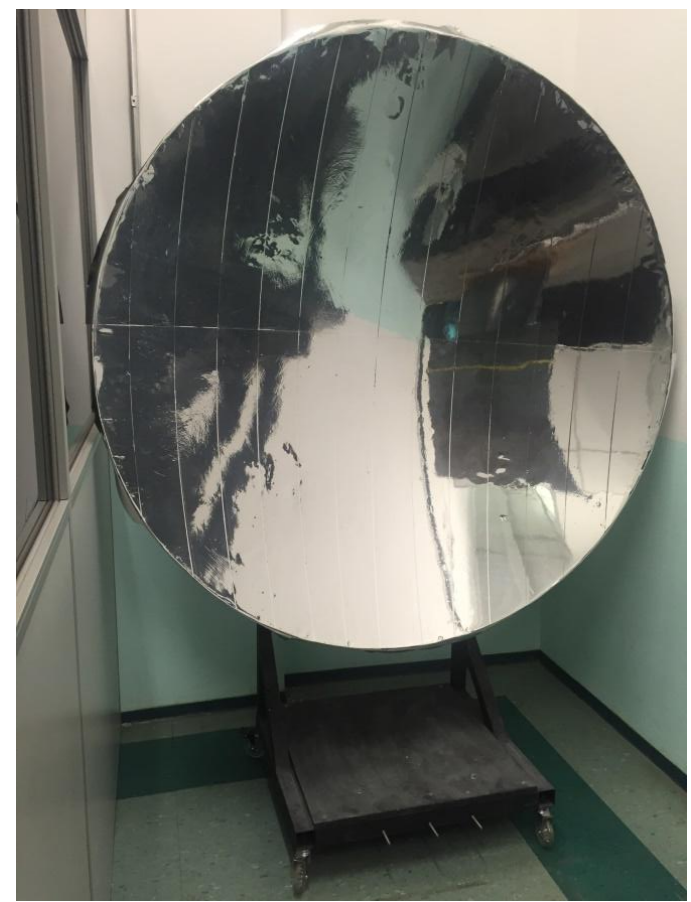

Figura A.1.16 - Refletor parabólico revestido com película autoadesiva refletora

Por fim, um suporte sobre rodas foi totalmente fabricado no laboratório para fixação do refletor parabólico. Este suporte móvel se fez necessário já que a instalação do refletor diretamente na parede do laboratório se mostrou inviável pelas dimensões restritas do espaço confinado para testes. Na Figura A.1.17 é possível observar a adaptação feita no refletor para a correta instalação no suporte móvel:
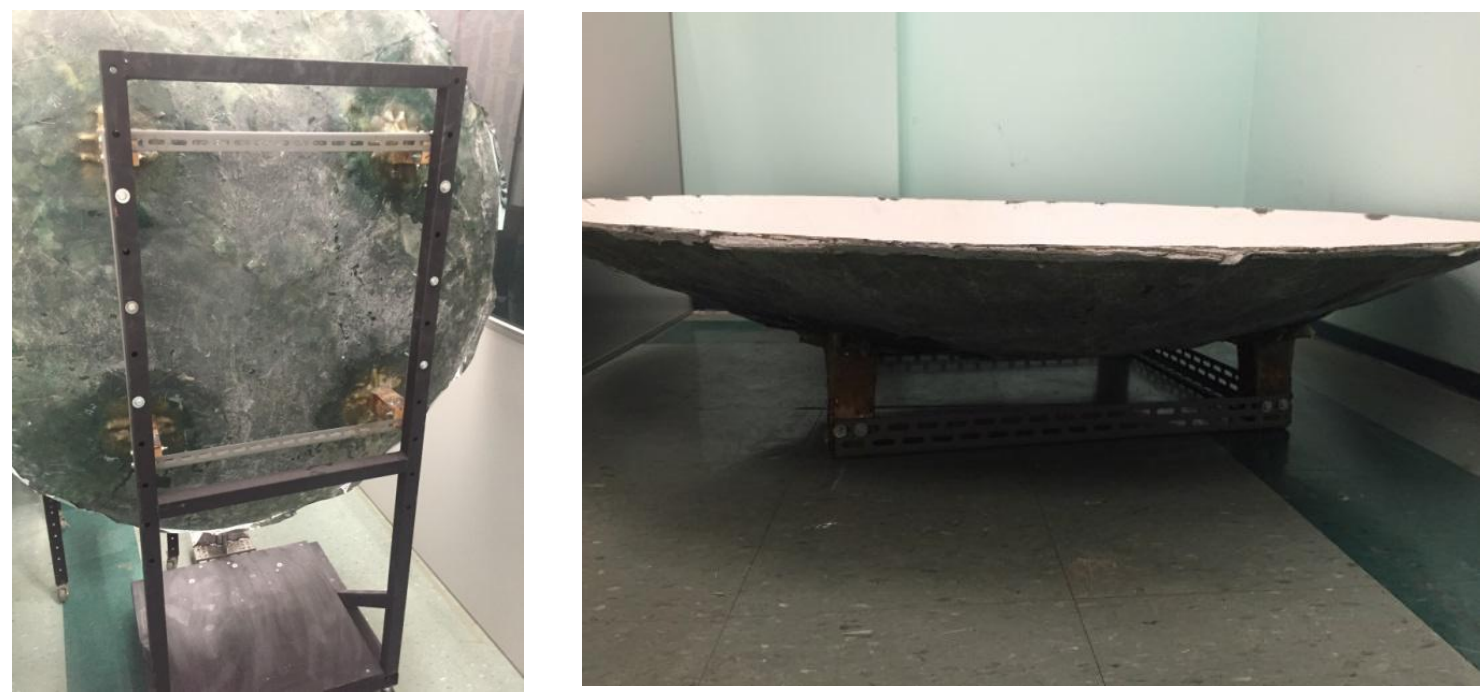

Figura A.1.17 - Suporte móvel e destaque para a adaptação feita no refletor para sua fixação no suporte 


\section{A.2 Adequação Estrutural do Laboratório}

Idealizada a configuração final do simulador solar, fabricado o refletor e adquiridos os equipamentos necessários, iniciou-se a fase de adequação do laboratório para a montagem do aparato. Conforme o layout completo da instalação apresentado na Figura 3.7, é essencial que o simulador solar apresente-se isolado da área comum do laboratório por um biombo ou divisória, a fim de garantir a segurança do operador e dos demais frequentadores, já que existe um pequeno risco de explosão do bulbo pressurizado caso a lâmpada sobreaqueça.

A primeira providencia tomada foi a contratação de uma empresa para 0 fornecimento e instalação dessas divisórias, a fim de se criar um espaço confinado no laboratório SISEA para a instalação do aparato completo do simulador solar. O resultado é apresentado na Figura A.2.1:
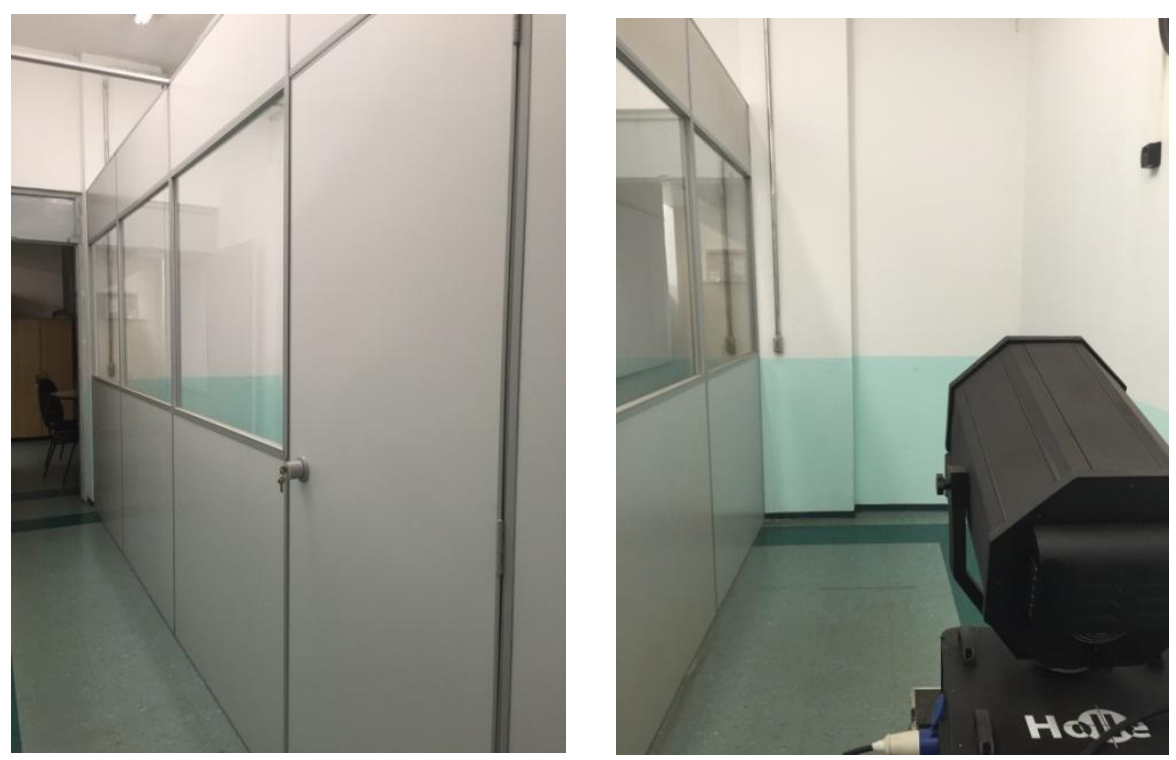

Figura A.2.1 - Resultado da instalação de divisórias para o confinamento do simulador solar

Tratando-se de um simulador solar acionado por lâmpadas de alta potência, a energia luminosa pode causar danos à visão dos frequentadores do laboratório, se 
em contato direto dos olhos com a fonte. Dessa forma, outra precaução tomada foi o revestimento do vidro das divisórias com película Insulfilm ${ }^{\circledR}$, conforme Figura A.2.2:
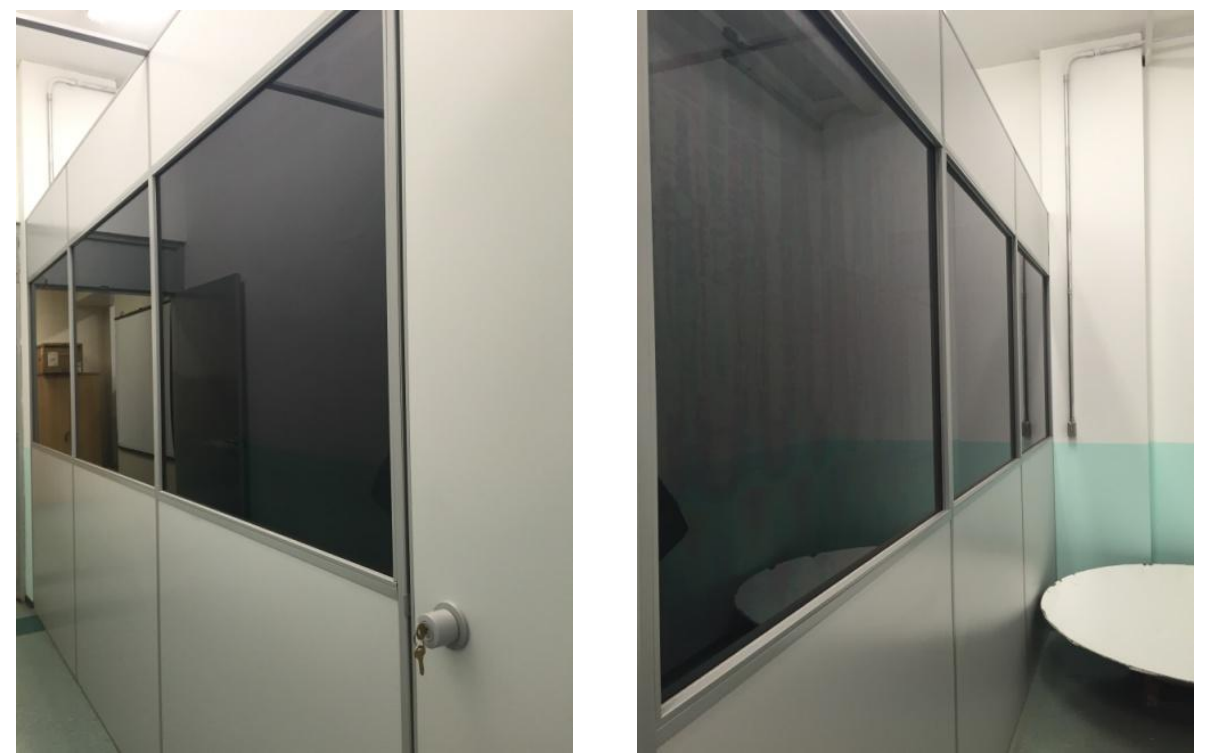

Figura A.2.2 - Destaque para os vidros das divisórias revestidos com película Insulfilm® A fim de garantir o conforto térmico do operador no espaço confinado e o controle rigoroso de temperatura do bulbo pressurizado da lâmpada, optou-se pela instalação de um exaustor axial industrial de $40 \mathrm{~cm}$ de diâmetro nas proximidades da fonte de luz, conforme figura abaixo:

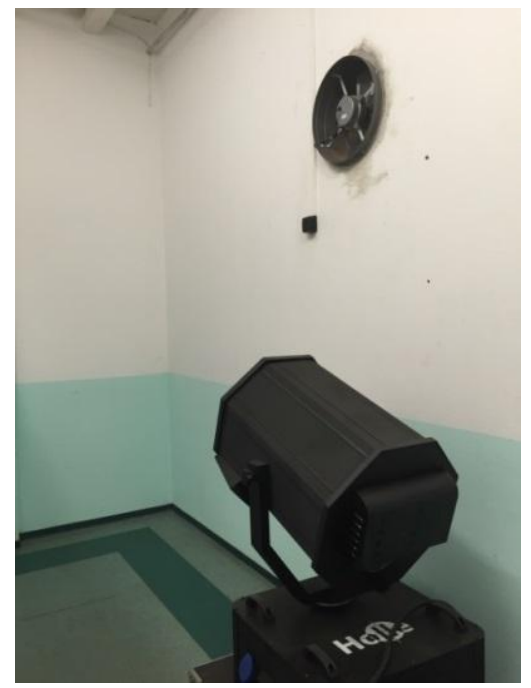

Figura A.2.3 - Destaque para o exaustor axial instalado no espaço confinado do simulador solar 
Em seguida, realizou-se para a adequação da instalação elétrica do laboratório, a fim de garantir a alimentação adequada dos equipamentos. Duas tomadas foram especialmente instaladas para alimentar os Sky Search Lights de 4.000W, e outra foi deslocada para suprir a demanda do exaustor adquirido, conforme Figura A.2.4:

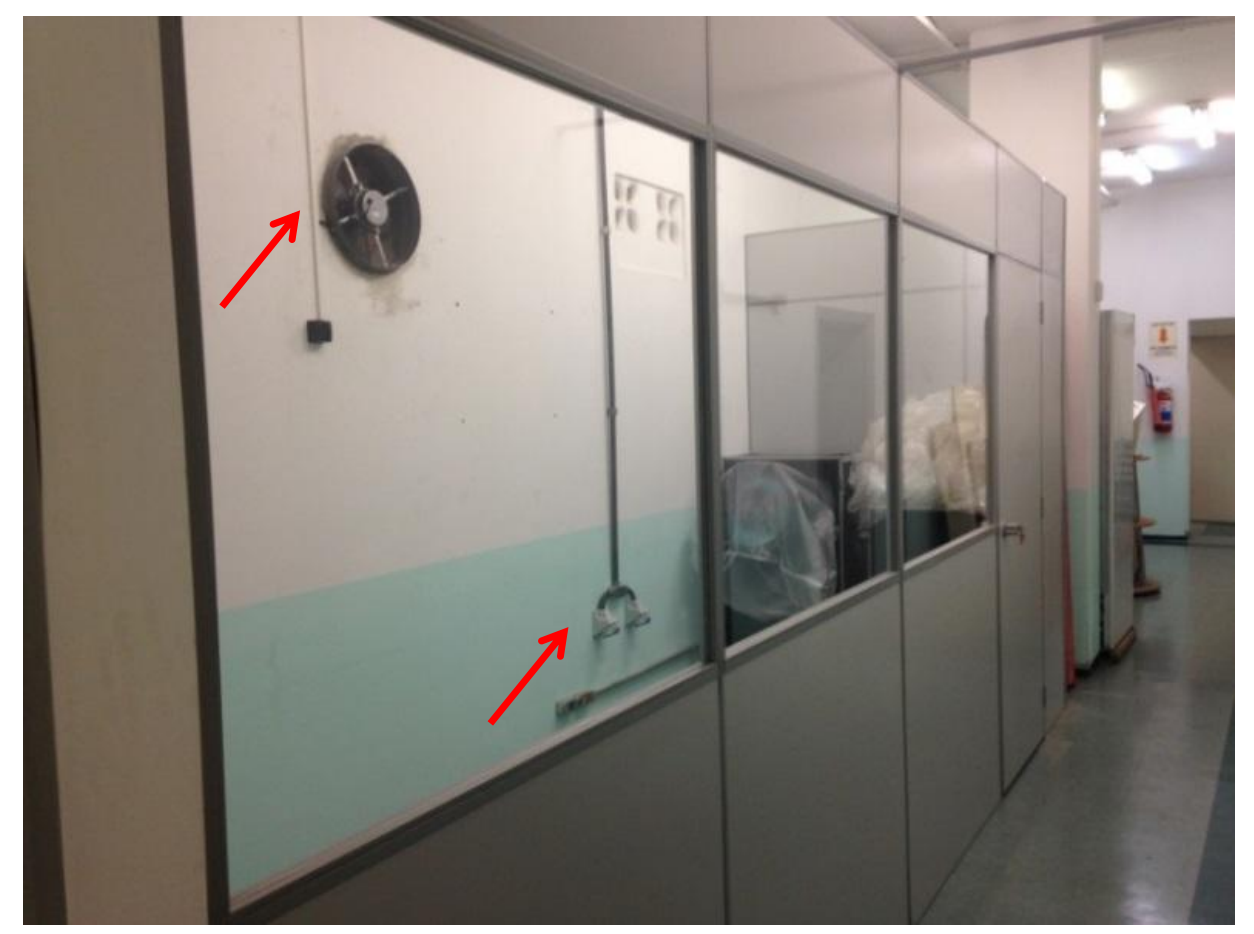

Figura A.2.4 - Nova instalação elétrica para alimentar os equipamentos adquiridos 


\section{A.3 Balanço Térmico por Analogia Elétrica da Cavidade Receptora}

A eficiência de absorção da cavidade receptora consiste na parcela de energia radiativa que adentra a cavidade e é efetivamente absorvida pelo circuito de água. $\mathrm{A}$ parcela restante de energia perde-se, em sua maioria, nas seguintes formas:

- Reflexão da luz incidente na entrada da cavidade receptora - a janela de quartzo posicionada na entrada da cavidade visa mitigar a perda de energia térmica por convecção. Em contrapartida, há uma pequena perda associada à refletância (baixa, porém não desprezível) do quartzo fundido;

- Re-irradiação - uma vez que a cavidade opera em temperaturas bastante elevadas, há uma perda considerável por irradiação;

- Condução/convecção - devido ao alto gradiente entre a temperatura ambiente e a temperatura interna, espera-se que uma quantidade considerável de energia deixe as paredes da cavidade por convecção.

Desta forma, a figura abaixo ilustra bem o balanço energético na cavidade receptora:

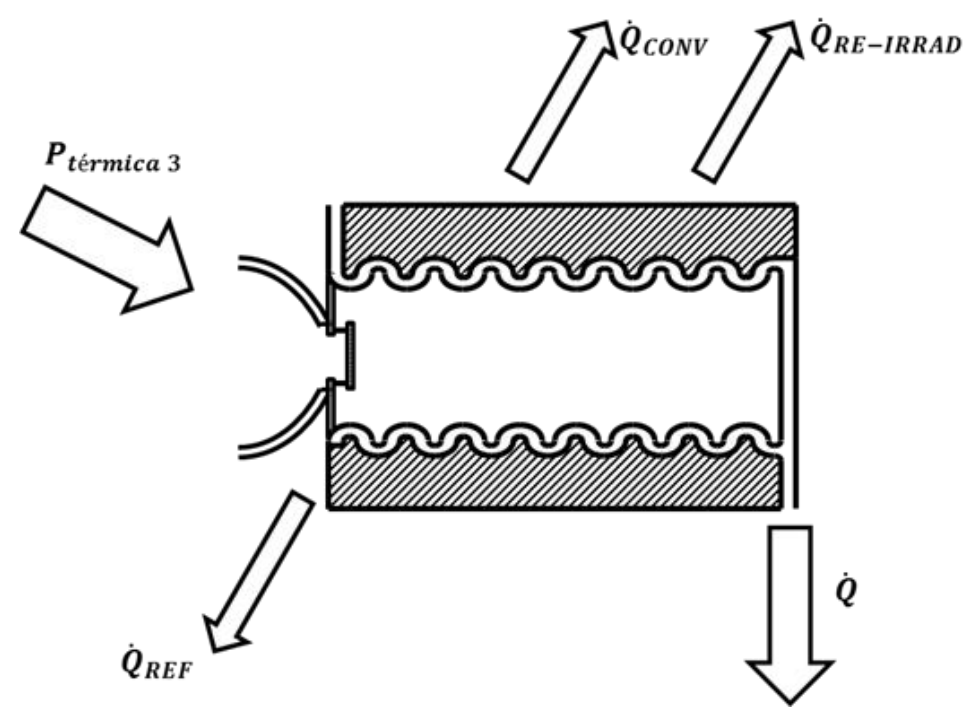

Figura A.3.1 - Representação esquemática do balanço térmico da cavidade receptora adaptado de Ribas (2016)

Segundo Ribas (2016), a eficiência de absorção da cavidade receptora pode ser estimada de maneira teórica, baseada no balanço térmico por analogia elétrica. Com 
esta técnica, os fluxos térmicos são representados como correntes elétricas, as temperaturas são incluídas nos circuitos como um potencial elétrico, e cada forma de troca térmica possui uma "resistência elétrica" associada.

O circuito elétrico equivalente da Figura A.3.1 é dado por:

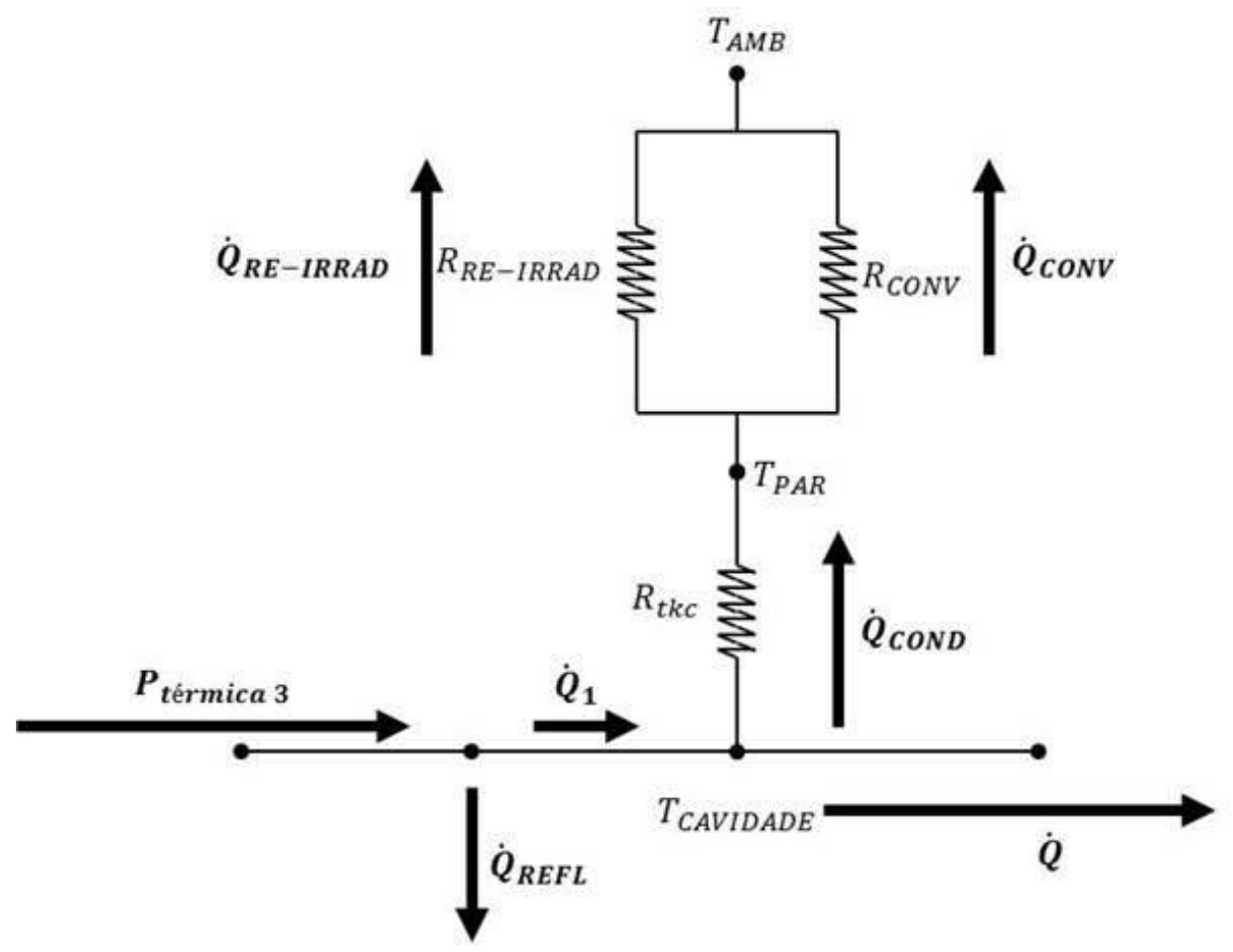

Figura A.3.2 - Representação do balanço térmico da cavidade receptora por analogia elétrica adaptado de Ribas (2016)

O sistema descrito acima foi solucionado a partir de uma planilha Excel e de alguns parâmetros de entrada fornecidos pelo usuário:

- Parâmetros geométricos da cavidade receptora

○ Diâmetro interno da cavidade $-D_{I N T}=113 \mathrm{~mm}$

- Espessura média da parede da cavidade $-e=18,5 \mathrm{~mm}$

- Comprimento da cavidade $-L=200 \mathrm{~mm}$ 


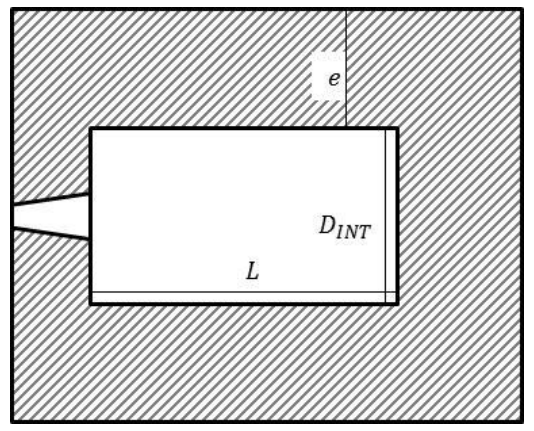

Figura A.3.3 - Dimensões consideradas na modelagem do balanço térmico da cavidade receptora - adaptado de Ribas (2016)

- Parâmetros dos materiais

○ Transmitância do quartzo $-\tau_{\text {JANELA }}=0,965$

○ Condutividade do material isolante $-k_{I S O}=0,5 \frac{\mathrm{W}}{\mathrm{mK}}$

○ Emissividade da parede externa da cavidade $-\varepsilon=0,7$

- Parâmetros de operação

○ Fluxo de calor no circuito de água $-\dot{Q}=1.182,53 \mathrm{~W}$

○ Temperatura medida no interior da cavidade $-T_{\text {cavidade }}=339,43 \mathrm{~K}$

○ Temperatura ambiente $-T_{A M B}=306,15 \mathrm{~K}$

○ Coeficiente de convecção do $\operatorname{ar}-h_{A R}=15,8 \frac{\mathrm{W}}{\mathrm{m}^{2} \mathrm{~K}}$

○ Constante de Stefan-Boltzman $-\sigma=5,67 \cdot 10^{-8}$

Em estudo orientado pelo professor doutor Cláudio Pacheco, as equações das resistências térmicas equivalentes são dadas pelas fórmulas a seguir:

- Resistência térmica condutiva total:

$$
\begin{gathered}
R_{\text {COND }}=R_{\text {CONAL }} D_{\text {LATERAL }}+R_{\text {COND }} \text { FUNDO } \\
R_{C O N D_{T O T A L}}=\frac{\ln \left(D_{E X T} / D_{I N T}\right)}{\mathrm{k}_{\mathrm{ISO}} \cdot 2 \pi \mathrm{L}}+\frac{\mathrm{e}}{\mathrm{k}_{\mathrm{ISO}} \cdot 2 \pi \mathrm{D}_{\mathrm{INT}}^{2} / 4}=0,36 \frac{K}{W}
\end{gathered}
$$

- Resistência térmica convectiva:

$$
R_{C O N V}=\frac{1}{h_{A R} \cdot \hat{A} R E A}=\frac{1}{h_{A R}\left(\pi D_{E X T} L+2 \pi D_{E X T}^{2} / 4\right)}=0,58 \frac{K}{W}
$$


- Resistência térmica de re-irradiação:

$$
R_{R E-I R R A D}=\frac{1}{\varepsilon\left(\pi D_{E X T} L+2 \pi D_{E X T}^{2} / 4\right) \sigma\left(T_{P A R E D E}^{2}+T_{A M B}^{2}\right)\left(T_{P A R E D E}+T_{A M B}\right)}=1,83 \frac{K}{W}(\mathrm{~A} .3 .4)
$$

Dessa forma, a Figura A.3.4 ilustra quantitativamente as parcelas das perdas térmicas na cavidade receptora estimadas pelo modelo acima descrito:

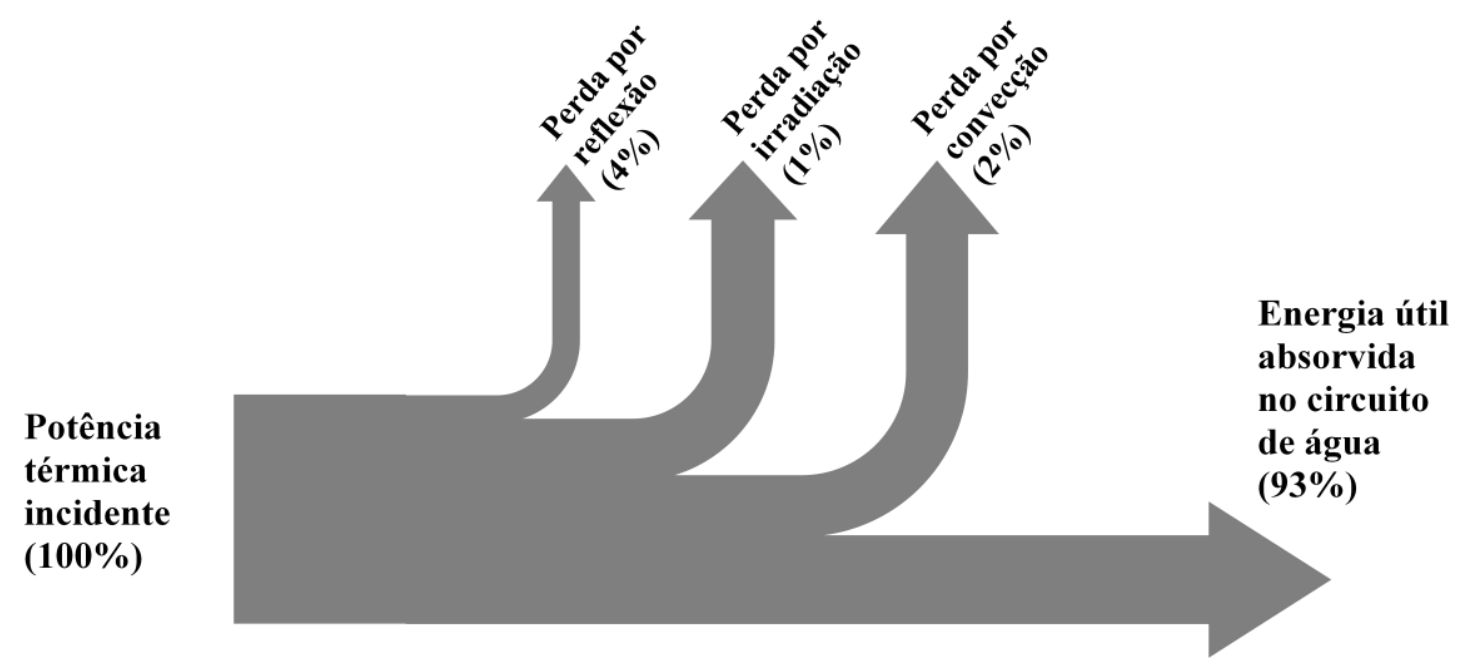

Figura A.3.4 - Diagrama quantitativo de perdas térmicas estimadas na cavidade receptora 


\section{A.4 Análise e Propagação de Incertezas}

$\rightarrow$ Propagação de incertezas:

\begin{tabular}{|c|c|}
\hline Operação & Propagação da incerteza \\
\hline $\boldsymbol{f}=\boldsymbol{a} \cdot \boldsymbol{A}$ & $\sigma_{f}^{2}=a^{2} \cdot \sigma_{A}^{2}$ \\
\hline $\boldsymbol{f}=\boldsymbol{A}+\boldsymbol{B}$ & $\sigma_{f}^{2}=\sigma_{A}^{2}+\sigma_{B}^{2}$ \\
\hline $\boldsymbol{f}=\boldsymbol{A}-\boldsymbol{B}$ & $\sigma_{f}^{2}=\sigma_{A}^{2}+\sigma_{B}^{2}$ \\
\hline $\boldsymbol{f}=\boldsymbol{A} \cdot \boldsymbol{B}$ & $\sigma_{f}^{2}=B^{2} \sigma_{A}^{2}+A^{2} \sigma_{B}^{2}$ \\
\hline $\boldsymbol{f}=\boldsymbol{A} / \boldsymbol{B}$ & $\sigma_{f}^{2}=f^{2}\left[\left(\frac{\sigma_{A}}{A}\right)^{2}+\left(\frac{\sigma_{B}}{B}\right)^{2}\right]$ \\
\hline
\end{tabular}

$\rightarrow$ Incertezas:

$$
\begin{gathered}
\sigma_{\mathrm{P}_{\text {elétrica }}}=\sqrt{I^{2} \sigma_{V}^{2}+V^{2} \sigma_{I}^{2}}=60 \mathrm{~W} \\
\sigma_{T_{\text {cavidade }}}=65,625^{\circ} \mathrm{C} / \mathrm{mA} \cdot 0,01 \mathrm{~mA}=0,7^{\circ} \mathrm{C} \\
\sigma_{T_{\text {ambiente }}}=1^{\circ} \mathrm{C} \\
\sigma_{T_{1}}=0,1^{\circ} \mathrm{C} \\
\sigma_{T_{2}}=0,1^{\circ} \mathrm{C} \\
\sigma_{\dot{V}}=13 \mathrm{~L} / \mathrm{h} \\
\sigma_{\eta_{\text {refletor }}}=0,01
\end{gathered}
$$


$\rightarrow$ Grandezas calculadas:

$$
\begin{aligned}
& \dot{Q}=(\rho . \dot{V}) \times c \times \Delta T \\
& \sigma_{\dot{Q}}=\rho \cdot c \cdot \sqrt{\Delta T^{2} \sigma_{\dot{V}}^{2}+\dot{V}^{2} \sigma_{\Delta T}^{2}} \\
& \sigma_{\dot{Q}}=\rho \cdot c \cdot \sqrt{\left(T_{2}-T_{1}\right)^{2} \sigma_{\dot{V}}^{2}+\dot{V}^{2}\left(\sigma_{T_{2}}^{2}+\sigma_{T_{1}}^{2}\right)} \\
& \sigma_{\dot{Q}}=84 W \\
& \dot{\eta}_{\text {concentração }}=\frac{\dot{Q}}{P_{\text {elétrica }} \times \dot{\eta}_{\text {equipamento }} \times \dot{\eta}_{\text {refletor }} \times \dot{\eta}_{\text {receptor }}} \\
& \sigma_{\dot{\eta}_{\text {concentração }}}=\frac{1}{\eta_{\text {equipamento }} \cdot \eta_{\text {receptor }}} \frac{\dot{Q}}{P_{\text {elétrica }} \cdot \eta_{\text {refletor }}} \sqrt{\left(\frac{\sigma_{\dot{Q}}}{\dot{Q}}\right)^{2}+\left(\frac{\sigma_{P_{\text {elétrica }} \cdot \eta_{\text {refletor }}}}{P_{\text {elétrica }} \cdot \eta_{\text {refletor }}}\right)^{2}} \\
& =\frac{1}{\eta_{\text {equipamento }} \cdot \eta_{\text {receptor }}} \frac{\dot{Q}}{P_{\text {elétrica }} \cdot \eta_{\text {refletor }}} \sqrt{\left(\frac{\sigma_{\dot{Q}}}{\dot{Q}}\right)^{2}+\frac{\eta_{\text {refletor }}{ }^{2} \sigma_{P_{\text {elétrica }}^{2}}+P_{\text {elétrica }}{ }^{2} \sigma_{\eta_{\text {refletor }}}^{2}}{\left(P_{\text {elétrica }} \cdot \eta_{\text {refletor }}\right)^{2}}} \\
& =6 \%
\end{aligned}
$$

